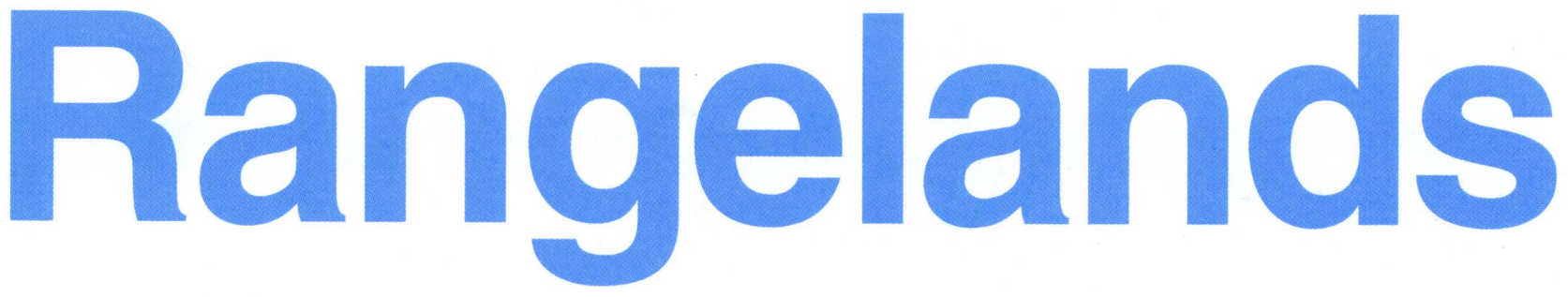

Society for Range Management

Vol. 23 No. 5, October 2001

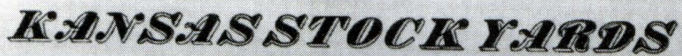

AT KANSAS CITY, MO.

\section{LARGEST ESTABLISHMENT}

OF THE KIND WEST OF THE MISSISSIPPI.

RAIl, COMMUNICATTONS EAST, WEST, NORTH and SOUTH.

EVERY FACILITY IS AMPLY FURNISHED FOR

Receiving, Yarding, Watering,

Feeding, Resting, Selling, WEIGHING AND SHIPPING

\section{VE STOCK} OF ALL DESCRIPTIONS.

YARDS FOR CATTLE FLOORED AND COVERED PENS FOR HORSES AND MULES.
HORSE

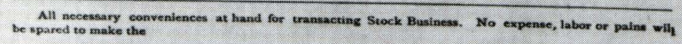

KANSAS STOCK YARDS THE LARGEST AND BEST POINT FOR CONCENTRATING LIVE
STOCK IN THE MISSOURI VALLEY.

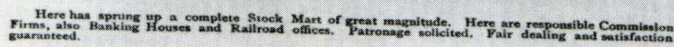
JEROME D. SMITH, Gen'I Supt.

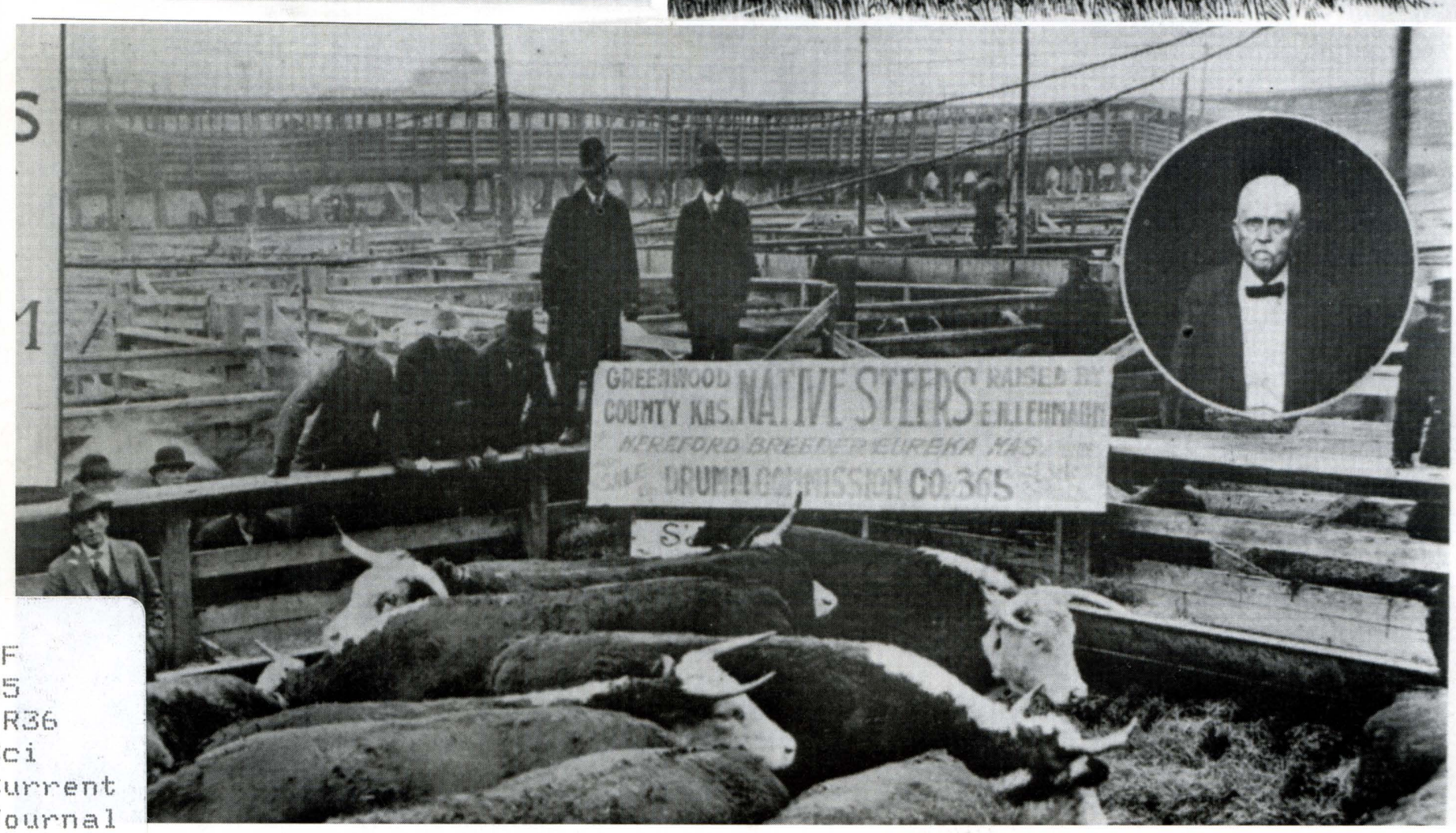

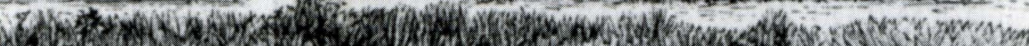
Whef

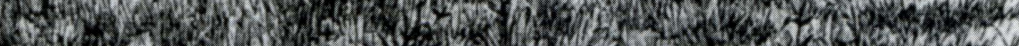
ofy (2) 24. s. 26.

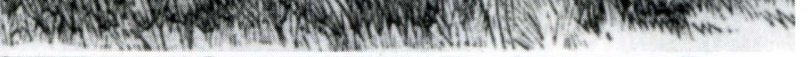




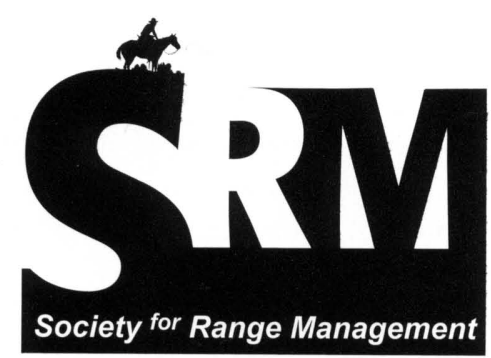

\author{
President \\ JIM O'ROURKE \\ Chadron State College \\ 61 Country Club Rd. \\ Chadron, Nebraska 69337-7323 \\ 1st Vice-President \\ RODNEY K. HEITSCHMIDT \\ USDA-ARS \\ Ft. Keogh LARRL \\ Rt 1, Box 2021 \\ Miles City, Montana 59301-9801 \\ 2nd Vice-President \\ BOB BUDD \\ Red Canyon Ranch \\ 350 Red Canyon Rd \\ Lander, Wyoming 82520-9417 \\ Executive Vice-President \\ SAMUEL W. ALBRECHT \\ Society for Range Management \\ 445 Union Blvd. Suite 230 \\ Lakewood, Colorado 80228 \\ (303) 986-3309 \\ Directors \\ 1999-2001 \\ JAMES A. LINEBAUGH \\ 3 Yhvona Dr. \\ Carson City, Nevada 89706-7717 \\ GLEN SECRIST \\ Idaho Dept. of Agriculture \\ 3818 S. Varian Ave. \\ Boise, Idaho 83709-4703

\section{0-2002} \\ RICHARD H. HART \\ USDA-ARS \\ High Plains Grasslands Station \\ 8408 Hildreth Rd. \\ Cheyenne, Wyoming 82009-8809 \\ DON KIRBY \\ North Dakota State University \\ Animal \& Range Science \\ Fargo, North Dakota 58105

\section{1-2003} \\ JOHN TANAKA \\ Eastern Oregon Agricultural Research Center-Union \\ P.O. Box E \\ Union Oregon 97883

\section{GREG TEGART} \\ BCMAFF \\ 1690 Powick Rd, Suite 2000 \\ Kelowna, BC V1X 7G5 \\ CANADA
}

The term of office of all elected officers and directors begins in February of each year during the Society's annual meeting.

SRM Office Staff, 445 Union Blvd., Suite 230, Lakewood, Colorado 80228; Telephone (303) 986-3309; Fax (303) 9863892; e-mail address: srmden@ix.netcom.com; home page http://srm.org

AARON BARR - Membership Services Manager SVETLANA GLUSHKO Office Service Assistant ANN HARRIS - Director of Administration/Programs PATTY RICH-Production Editor

KIRSTEN TARDY - Director of Accounting \& Sales

\section{The Society for Range Management}

The Society for Range Management founded in 1948 as the American Society of Range Management, is a nonprofit association incorporated under the laws of the State of Wyoming. It is recognized exempt from Federal income tax, as a scientific and educational organization, under the provisions of Section 501(c) (3) of the Internal Revenue Code, and also is classed as a public foundation as described in Section 509 (a) (2) of the Code. The name of the Society was changed in 1971 by amendment of the Articles of Incorporation.

The objectives for which the corporation is established are:

- to properly take care of the basic rangeland resources of soil, plants and water;

-to develop an understanding of range ecosystems and of the principles applicable to the management of range resources;

-to assist all who work with range resources to keep abreast of new findings and techniques in the science and art of range management;

- to improve the effectiveness of range management or obtain from range resources the products and values necessary for man's welfare;

- to create a public appreciation of the economic and social benefits to be obtained from the range environment;

- to promote professional development of its members.

Membership in the Society for Range Management is open to anyone engaged in or interested in any aspect of the study, management, or use of rangelands. Please contact the Executive Vice-President for details.

\section{$R$ angelands}

Rangelands serves as a forum for the presentation and discussion of facts, ideas, and philosophies pertaining to the study, management, and use of rangelands and their several resources. Accordingly, all material published herein is signed and reflects the individual views of the authors and is not necessarily an official position of the Society. Manuscripts from any source-nonmembers as well as members-are welcome and will be given every consideration by the editors. Rangelands is the nontechnical counterpart of the Journal of Range Management; therefore, manuscripts and news items submitted for publication in Rangelands should be in nontechnical nature and germane to the broad field of range management. Editorial comment by an individual is also welcome and, subject to acceptance by the editor, will be published as a "Viewpoint."

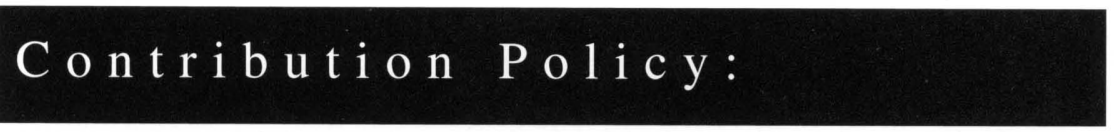

The Society for Range Management may accept donations of real and/or personal property subject to limitations set forth by State and Federal law. All donations shall be subject to management by the Executive Vice President as directed by the Board of Directors and their discretion in establishing and maintaining trust, memorials, scholarships or other types of funds. Individual endowments for designated purposes can be established according to Society policies. Gifts, bequests, legacies, devises, or donations not intended for establishing designated endowments will be deposited into the SRM Endowment Fund. Donations or request for information on Society policies can be directed to the Society for Range Management, Executive Vice President, 445 Union Blvd., Suite 230, Lakewood, Colorado 80228. We recommend that donors consult Tax Advisors in regard to any tax consideration that may result from any donation. 


Volume 23 No. 5
October 2001
Published bimonthly_February, April, June, August,
October, December
Copyright 2001 by the Society for Range Management
Managing Editor
KINDRA GORDON
P.O. Box 645
Spearfish, South Dakota 57783
(877) 347-9123
E-Mail: kindrag@tsln.com
Editor/Copy Editor
GARY/JO FRASIER
7820 Stag Hollow
Loveland, Colorado 80538
(970) 663-3094
E-Mail: gfrasier@lamar.colostate.edu

Production Editor

PATTY RICH

3059A Hwy 92

Hotchkiss, Colorado 81419-9548

(970) 872-5932

E-Mail: prich@starband.net

Book Review Editor

DAVID L. SCARNECCHIA

Dept. Natural Res. Sci.

Washington State University

Pullman, Washington 99164-6410

E-Mail: scarneda@mail.wsu.edu

Editorial Board

1999-2001

JAMES BRUNNER, Medford, Oregon

DAN ROBINETTE, Tucson, Arizona

MARILYN J. SAMUEL, Lehigh Acres, Florida

JAN WIEDEMANN, College Station, Texas

2000-2002

LYNN HUNTSINGER, El Cerrito, California

JOHNMITCHELL, Fort Collins, Colorado

KIETHSEVERSON, Isle, Minnestoa

AMY SMITH, Burns, Oregon

2001-2003

DAVIDBRADFORD, Paonia, Colorado

RANDEL DONGES, Dalhart, Texas

MICHAELFRISINA, Butte, Montana

ART MEANS, Fredonia, Arizona

INDIVIDUAL SUBSCRIPTION is by membership in the Society for Range Management.

LIBRARY or other INSTITUTIONAL SUBSCRIPTIONS, on a calendar year basis, are $\$ 65.00$ in the United States, $\$ 89.00$ in all other countries. Payments from outside the United States should be remitted in US dollars by international money order or draft on a New York bank.

BUSINESS CORRESPONDENCE, concerning subscriptions, advertising, back issues, and related matters, should be addressed to the Managing Editor, 445 Union Blvd., Suite 230,

Lakewood, Colorado 80228, Phone 303-986-3309.

EDITORIAL CORRESPONDENCE, concerning manuscripts or other edited matters, should be addressed to the Technical Editor, 7820 Stag Hollow Road Loveland, Colorado 80538.

RANGELANDS (ISSN-0190-0528) is published six times yearly (February, April, June, August, October, and December) by the Society for Range Management, 445 Union Blvd., Suite 230, Lakewood, Colorado 80228, Phone 303986-3309. PERIODICALS POSTAGE paid at Denver, Colorado and additional offices.

POSTMASTER; Return entire journal with address change-Address Service Requested-to Society for Range Management, 445 Union Blvd., Suite 230, Lakewood, Colorado 80228 .

PRINTED IN THE USA

\section{Rangelands}

FEATURE ARTICLES

Development Of The National Cattle Trade

by $K C$ Olson . . . . . . . . . . . . . . . . . . . . . 3

The Commission Merchant

by $K C$ Olson ...................... 7

Reform Of The Livestock Trade

by $K C$ Olson . . . . . . . . . . . . . . . . . . . .13

Regulation Of The Livestock Trade

by KC Olson . . . . . . . . . . . . . . . . . . . .17

Charting Our Changing Course

by Urs P. Kreuter and Michael P. Schellenberg . . . . . . . .22

Preparing For The Future Of Range Science

by Urs Kreuter . . . . . . . . . . . . . . . . . . . .24

Range Management's Record

by Thad Box . . . . . . . . . . . . . . . . . . . . . .27

Grass-Fed: Nature's Intention

by Dawn Rahn . . . . . . . . . . . . . . . . . . . . . 30

Annual Bromes-Good Or Bad?

by Marshall R. Haferkamp . . . . . . . . . . . . . . . . . 32

\section{DEPARTMENTS}

2 EVP Comments

37 Letter To The Editor

38 Interpretive Summaries

43 Book Review
36 Resource Roundup

37 Requiescat In Pace

41 Browsing The Literature

44 Founding/Charter Members

\section{COVER}

COVER PHOTO: Front Cover: Historical photos from the Kansas City Historical Society, Topeka, Kansas. See related stories starting on page 3. We spotlight Kansas City role in cattle trade as we prepare for the 2002 SRM convention in that city. Back Cover: Photo taken near Billings, Montana by Kindra Gordon. 


\section{EVP's Comments}

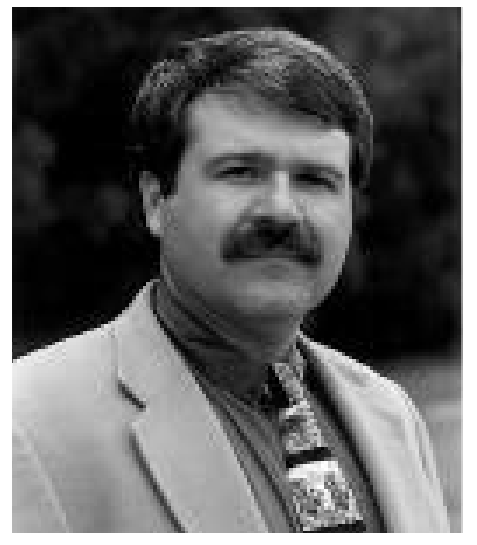

Although most of the Y2K and New Millennium hype has died down, I am still excited, amazed, and a little terrified about the future. We are entering a new age of change that is going to be impacting much of our day-to-day personal and business lives. A lot of the changes are the results of the new technology we have seen in the past 10 years.

This technology has made information a new currency. For example, at 5:45 this morning, I sat down in front of the TV and got my latest data dump from CNN Headline news. I received the latest news on the conflict in the Middle East, the status of the shrinking U.S. budget surplus, and the location of the latest forest fires.

While the value of this information is questionable, the perceived value on my part is great. I feel a need to be informed. I feel a need to get that daily update. My thought processes are moving from local to global knowledge.

I got to work about 7:15 and what's the first thing I do? Check my email. I have a half dozen messages regarding this project or another, and a couple of listserv digests. These listservs work much the same as CNN Headline News. They deliver information on current topics. Listservs are a little more interactive than television - the members are able to post topics/questions and receive feedback from peers around the country. But again, the basic information delivery/update process is much the same.

Information gathering is certainly increasing. Just think of satellite imagery. Developed as a military surveillance application over twenty years ago, today it's readily available to you and me. The same goes for the global positioning system (GPS). If trends continue, think of the capabilities we may see in the next 20 years.

I believe information sharing is going to be even more impacted by technology than many of us realize. Information sharing can take on a variety of methods. For example, two guys talking is information sharing - as is a peer reviewed paper in a scientific journal, an article on a website, and a listserv.

The level of detail in the information we receive is also rapidly increasing. New tools and technologies have made digital images and in-depth data collection a standard practice. Massive amounts of data can be analyzed in mere seconds with today's computers and programs. Comparing my first PC (a Commodore 64 I used in college) to my current machines (one on my desk at home, one on my desk at work, and a notebook if I have to leave either location for more than a day), I am amazed at the difference. What are desktop computers going to look like in another 20 years?

Information access is also increasing. The United States is becoming more "wired" every day. Our members and our public in the U.S. are demanding this connectivity because of their need for information. Newspapers are not enough. Television isn't specific or fast enough. People want to selectively pull information from that beast called the World Wide Web. If information is a currency, and currency has always been associated with power, then I worry that our newfound wealth is going to result in a greater separation between those with connectivity and those that don't have it. Vast areas of rangelands exist in countries where information, and connectivity isn't as readily available. We must all continue to think globally.

Information processing is the area I see the biggest potential for changes. We have all these gigabytes available from the greatest information-sharing platform we could have imagined. Our access is increasing. Remember 14.4 kbs? Now we have $56.6 \mathrm{kbs}$ standard as dial-up, not to mention ISDN, DSL, cable, and wireless. Buildings (both homes and businesses) are being designed with access in mind. Tenants of office buildings are banding together to purchase T-1 lines. Simple Internet search engines return thousands of potential answers to queries. When I asked about "range management", www.google.com provided 2.9 million results. How in the heck am I supposed to process all that data? I won't. I'll look for experts to process the sub-level data into pieces that I will then pull from a variety of sources in order to make the decisions I need to make.

What does any of this have to do with SRM? We are in the information business. We gather, we share, and we process both to our members and non-members. You, our members, do the same thing. We need to factor this into our programs and processes to better serve you our members. Our publications and websites must be geared to provide these functions. Our strategic plan is going to help us do that. Our website is going to help us do that. Our leadership must continue to consider these future trends to ensure that SRM is recognized as the premium storehouse, processor and provider of information for range management. 


\title{
Development Of The National Cattle Trade
}

\section{Kansas City played a central role in the development of the nation's cattle trade in the $19^{\text {th }}$ Century.}

\author{
By KC Olson
}

The $19^{\text {th }}$ century was characterized by rapid change and reorganization in American agriculture. The affluent, urban populace of the eastern United States demanded that their food and textiles be plentiful, varied, and of high quality. As rail transportation and telegraph communication developed, national markets for agricultural commodities emerged.

Prior to the 1840 s, the traditional mercantile firm marketed and distributed the nation's goods. Early largescale trade across state lines was chaotic and inefficient; there was little organized commerce. Out of this chaos, a new class of merchant appeared. The commodity broker - a middleman between the producer and the buyer arranged the purchase, transport, and delivery of agricultural products across the nation and brought an organizational revolution to agriculture.

Within a generation, the modern commodity dealer replaced the mercantile firm. This new form of administrative coordination reduced the number of transactions in the flow of goods, increased the speed and regularity of flow, and consequently, lowered costs and improved the productivity of the nation (Hazlett 1987).

The commodity broker came to totally dominate the movement of grain. These commodity brokers organized the Chicago Board of Trade in 1848 (Johnson 1911). In so doing, the commodity brokers provided a new opportunity for the nation's agriculturalists. Farmers and ranchers were no longer relegated to subsistence living, barter, and limited local markets from which to extract a living. Even the most isolated of farmers and ranchers were able to achieve national distribution of their products via the commodity broker, the railroad, and the telegraph.

This organizational revolution was not unique to grain and textiles. It also occurred in the distribution of livestock throughout the United States but with a few notable differences. The railroads created a national market for beef, pork, and mutton when they opened the Great Plains and the Southwest to trade. The KansasPacific Railway pressed into Kansas and Colorado in the 1860 s and the Missouri, Kansas, and Texas Railway opened the Texas overland trade in the early 1870s (Hazlett 1995).

As the railroad enabled the transport of animal products from the production centers of the west to the population centers of the east, another type of broker appeared - the livestock commission merchant. Unlike the commodity brokers who never left the mercantile exchange offices and only saw samples of the commodity traded, the commission merchant traveled between the farms and ranches of the Southwest and the trading centers of the Midwest. They personally monitored the transport of specific animals on the railroad. The livestock commis-

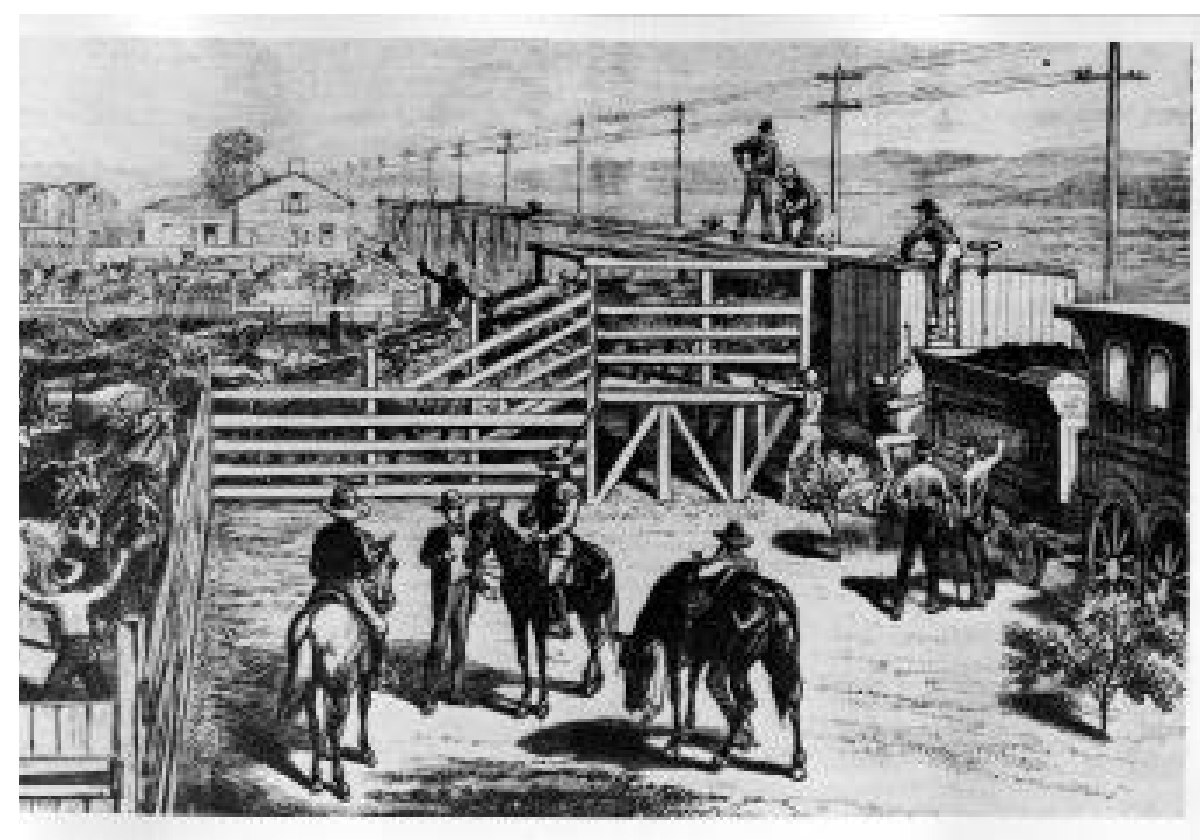

Following the Civil War, drovers brought cattle overland to the railhead towns of Kansas for rail shipment to the market centers in Kansas City and Chicago. Cattle shown here are being shipped from Abilene, Kansas. Provided by the Kansas State Historical Society Topeka, Kansas. Reprinted with permission. 


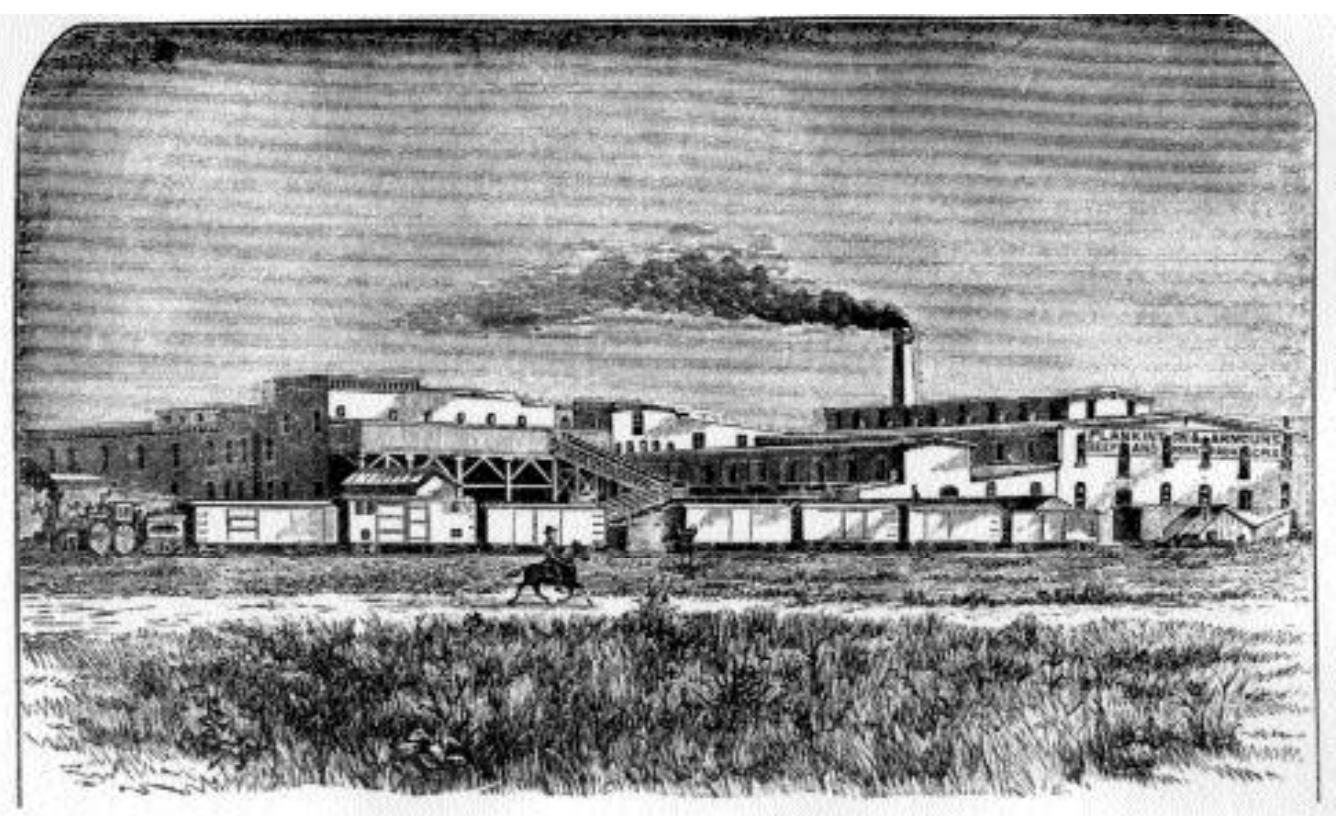

The Phillip Armour packing plant, shown as it appeared in 1870, established Kansas City as a major meatpacking center. Provided by the Kansas State Historical Society - Topeka, Kansas. Reprinted with permission.

sion merchants established markets similar to a grain exchange. The Chicago and Kansas City Live Stock Exchanges organized in 1884 and 1886, respectively, almost forty years after the Chicago Board of Trade (Thompson 1900).

Bulk commodities graded and standardized easily and were sold through futures markets that were pioneered in the U.S. by the Chicago Board of Trade during the mid-1900s. Conversely, livestock could not be standardized easily for the purposes of trade and, thus, could not be sold through the futures markets. Animals were alive, mobile, disease prone, and easily injured. Each animal was unique in weight and quality of meat. These problems made it necessary to continue to trade livestock on a spot cash market (Hazlett 1995). Live animals still required human oversight at every step in the marketing process; there still had to be personal contact between buyers, sellers, and merchandise.

Not until the late $20^{\text {th }}$ century did modern cattle feeding practices, selective breeding, and veterinary science bring some standardization to the trade. In 1974, more than one hundred years after the grain trade established futures markets, the Chicago Mercantile Exchange first traded in live cattle futures (Ball 1992). The $19^{\text {th }}$ century commission merchant, to cope with the vagaries of live animal trading, introduced many marketing innovations that are still in use today. Kansas City, site of the Society for Range Management 2002 Annual Convention, was the focal point for reorganization and nationalization of the cattle trade in the United States during the late $19^{\text {th }}$ century.

\section{The History Of Livestock Trade}

After the civil war, drovers moved market-ready cattle out of the Southwest in large numbers to railheads in the eastern Great Plains. In 1885 , one Texas drover could move efficiently a maximum of 3,000 animals at a time. The job required 11 cowboys, a trail boss, food, horses, equipment, and an entire summer's work (Hazlett 1995). Anytime the distance to market was too great for a rancher to sell his own livestock, a drover served that function. During the 1860 s and 1870 s, drovers purchased livestock in their home state and then sold them, after a long trail drive, in northern states. Sale of the cattle was typically arranged at one of the railhead towns of the Central Plains.

Exorbitant price markups brought the activities of drovers into question. A drover could buy a 2-year-old steer in Texas for $\$ 8.70$ and market it in Kansas for as much as $\$ 23.32$ for a price markup of $268 \%$. The markup was even higher for a 4-year-old steer (369\%; Galenson 1977). The producer received roughly a third of the final sale price under this system, while the middleman received about two-thirds. Dissatisfied with this state of affairs, cattlemen wanted to retain a greater share of the value of their animals and were easily persuaded to seek more equitable methods of marketing.

As railroads built further into the Southwest, alternative methods of livestock marketing became a possibility. A person could finally transport cattle over land faster than the animal could walk. It was no longer necessary to sell livestock locally to a drover in order to tap the competitive livestock markets of the Midwest. The railroads provided most ranchers themselves with the needed market access. By the early 1870 s, railroads were collecting thousands of cattle off the grasslands 
of the Southwest and bringing them into Kansas City for national distribution (Hazlett 1995).

A trip from Las Animas, Colorado to Kansas City via the Santa Fe Railroad took two days in 1873; the trip to Chicago took 5 days. Ten years later, the journey to Kansas City could be made in 28 hours (Hazlett 1995). Moving animals great distances by train introduced livestock owners to the concept of shrink. Confinement for long hours without feed or water caused livestock to experience significant weight loss while aboard the trains. Producers closer to the stockyards were at an advantage; their livestock experienced little shrinkage in weight during the trip.

Cattlemen quickly learned this lesson. Many moved their herds to the rangelands of Indian Territory south of Caldwell, Kansas prior to selling them. When the price of cattle in Kansas City rose to an adequate level, they would quickly load their herds aboard stock trains and ship them to take advantage of the price change. Grazing transient cattle on the grasslands south and west of Kansas City became common in the ranching business. The bluestem pastures of the Kansas Flint Hills around Emporia supported thousands of transient cattle each summer that had been shipped from west Texas for a few months growth and fattening. The 101 Ranch in the Texas panhandle purchased 75,000 acres in the Flint Hills for this purpose (Hazlett 1995).

\section{Kansas City's Role}

Kansas City was a logical center of operations for the new and burgeoning national market in livestock. It was a town of only 32,000 residents in 1870 when Phillip Armour built a packing plant there; however, it was nearer the source of Southwestern beef than the primary competing market in Chicago. Just 16 years later, Kansas City had seven packing plants that employed 2,234 workers (Snyder 1893).

Meatpacking, because of a lack of refrigeration, was seasonal until 1877

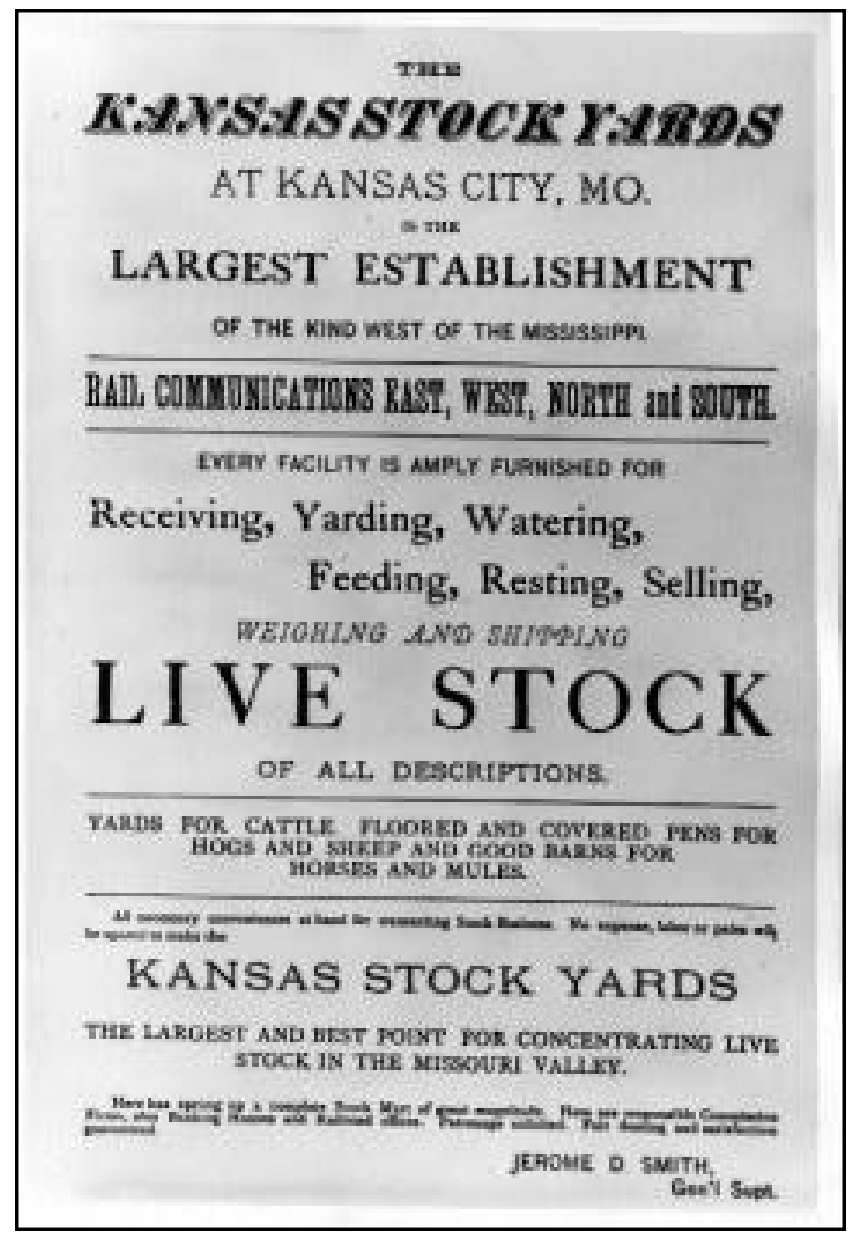

The handbill pictured here is an early advertisement for the services available at the Kansas City Stockyards. Provided by the Kansas State Historical Society - Topeka, Kansas. Reprinted with permission.

when the Armour packing plant installed a chill room enabling yearround work. Beginning in that year, Kansas City became the primary supplier of packed beef to the United States (Renner 1960). After that time, beef packing in Chicago dwindled into comparative insignificance because of the large number of cattle processed at Kansas City (Taylor 1917).

It would be incorrect to suggest that the Chicago market did not play a significant role in the advance of the national livestock trade. It certainly did; however, the Kansas City and Chicago markets dominated fairly distinct, non-overlapping regions of the country because of the pattern of railroad development. A railroad inspector stationed at Kansas City along the Santa $\mathrm{Fe}$ railway recorded 8,988 railcars of cattle shipped in 1890. Bills of lading for these cars indicated that $85 \%$ stopped in Kansas City, while only $15 \%$ went to Chicago. These figures can be interpreted to suggest that the Kansas City market dominated the trade out of Southwest Kansas, Colorado, Indian Territory, the panhandle of Texas, and New Mexico.

In contrast, the Missouri, Kansas, \& Topeka railroad shipped the majority of Texas cattle by virtue of its more easterly routing. A railroad inspector in Southeastern Kansas reported that of 8,500 cars shipped from the north Texas area in $1890,69 \%$ went to Chicago, $17 \%$ to St. Louis, and only $14 \%$ went to Kansas City (Hazlett 1995). The Chicago market clearly dominated the Texas Cattle trade, largely because of the pattern of rail 
development. Railroads that were headquartered in Kansas City were late building into Texas. The pattern of regional dominance established during the early days of the national cattle trade persisted into the $20^{\text {th }}$ century as a result.

Initially, Kansas City lacked an organized livestock market. Packer representatives had to travel into the countryside to buy livestock. A number of Kansas City businessmen, recognizing this inefficiency, chartered the Kansas City Stockyards Company in 1871 (Renner 1960). The Kansas City Stockyards Company provided a location where buyers and sellers could congregate to transact business. It was complete with rail lines, animal handling facilities, and livestock scales. In 1893, the stockyards covered about 100-acres along the Kansas-Missouri border. The entire area was floored with 3-inch cypress plank. Its daily capacity was 20,000 cattle, 35,000 hogs, and 15,000 sheep; 300 men were needed to handle, feed, and care for all of the stock (Snyder 1893).

Kansas City was reborn over a period of little more than 20 years as the major livestock marketing and meatpacking center in the United States. This, combined with deeper penetration of the railroads into the grasslands of the West, enabled cattlemen to transport their animals to a competitive, national market and, for the first time, negotiate the sale of their cattle face-to-face with a number of potential buyers. Most importantly, the new system enabled cattlemen to capture a greater share of the value of their animals. As long as the Kansas City stockyards remained relatively small, a rancher could find a buyer without assistance; however, the volume of animals soon increased to the point that the stockyards became large, impersonal, and confusing (Hazlett 1995).

The Kansas City market offered a wider selection of more reasonably priced animals than competing markets in Buffalo or Philadelphia. This circumstance prompted large numbers of eastern commodity merchants to travel to Kansas City relatively soon after the organization of the Kansas City Stockyards Company. The large concentration of buyers and sellers at the stockyards caused livestock prices to fluctuate wildly, up to $30 \%$ in a single day. A producer who attempted to market his own livestock frequently sold for less than market price. No one but an expert could determine when to make a sale for optimum return within the Kansas City market.

An additional complication was the fact that cattle alone had 14 classifications for the purposes of marketing: fancy cattle, choice cattle, good shipping steers, medium shipping steers, common to fair steers, common to choice bulls, good to choice cows, poor to medium cows, stockers and feeders, northern range steers, Texas steers, Texas cows, veal calves, and milk cows. The plethora of classifications meant that the seller had to find multiple buyers for each load of stock brought to Kansas City. Finding all these buyers was difficult. Only someone intimately familiar with the market knew all of the buyers and what types of cattle they sought. These factors meant that a cattleman could no longer market his own livestock without encountering significant price risk (Hazlett 1987).

The author is an assistant professor, Department of Animal Sciences, University of Missouri - Columbia, Columbia, MO 65211, to whom correspondence should be addressed

\section{References}

Ball, C. E. 1992. The Finishing Touch: A History of the Texas Cattle Feeders Association and Cattle Feeding in the Southwest. Texas Cattle Feeders Association, Amarillo, TX.

Galenson, D. 1977. The profitability of the long drive. Agricultural History 51: 737758.

Hazlett, O. J. 1987. Regulation in the livestock trade: the origins and operations of the Kansas City Livestock Exchange 1886-1921. Ph. D. Dissertation. Oklahoma State University, Stillwater.

Hazlett, O. J. 1995. Cattle marketing in the
American Southwest. Kansas History 18(2):100-115.

Johnson, E. R. 1911. American produce exchange markets. The Annals of the American Academy of Political and Social Sciences 38:319-320.

Renner, G. K. 1960. The Kansas City meat packing industry before 1900. Missouri Historical Review 55:18-29.

Snyder, E. 1893. Livestock markets of Kansas. In: Kansas State Board of Agriculture, Quarterly Report, March 1893. Hamilton Printing Co., Topeka, KS.

Taylor, C. H. 1917. History of the Chicago Board of Trade, Volume 1. O. Law, Chicago, IL.

Thompson, W. H. 1900. Livestock exchanges. In: Proceedings of the National Live Stock Association. Smith-Brooks Printing Co., Denver, CO. pp 232-236. 


\title{
The Commission Merchant
}

\section{Livestock commission merchants helped garner higher prices for producers, but the new national livestock trade was also plagued with animal disease and unethical practices.}

\author{
By KC Olson
}

As the size and scale of the Kansas City stockyards increased, it became increasingly difficult for individual ranchers and farmers to market their own animals effectively. Farmers and ranchers lacked market savvy and familiarity with stockyards personnel, which reduced the likelihood of a suitable financial return. This set of circumstances pointed to the need for an intermediary between buyer and seller within the Kansas City stockyards.

The livestock commission merchant appeared to fill this void. Commission merchants arranged the sale of livestock for a consignment fee. They carried out this task not only within the Kansas City stockyards, but often traveled over great distances to locate, solicit, and sell livestock from all over the Southwest. In 1887, 40 livestock commission firms were operating in Kansas City. That number eventually increased to 300 , a figure which remained constant well into the $20^{\text {th }}$ century (Hazlett 1995). The commission merchants operated continuously in the Kansas City stockyards. As such, they were expert observers of price trends and were familiar with the many order buyers and packer buyers who frequented the stockyards. Commission merchants reduced much of the risk associated with marketing livestock in Kansas City by helping livestock owners to choose opportune marketing windows and arranging for the simultaneous sale of multiple classes of livestock.

Surprisingly, they did so at a relatively small cost. The standard con- signment charge was initially $50 \phi$ head for cattle and $10 \phi$ for hogs or sheep. Later, an equivalent charge of \$12/railcar was established for cattle. Similarly, $\$ 6 /$ single-deck railcar or $\$ 10 /$ double-deck railcar was assessed for hogs and sheep (Hazlett 1995). Commission rates for cattle remained constant for 36 years between 1886 and 1921. During that same era, the price of cattle varied from a low of $\$ 3.65 /$ hundredweight in March of 1889 to a high of $\$ 9.60 /$ hundredweight in August of 1912 (Hazlett 1987). The attractive and eminently fair rate scale of the commission merchants soon made selling livestock on consignment the preferred marketing method in the industry.

\section{Commission Merchants Replaced Drovers}

Instead of leveraging $66 \%$ of the value of an animal as a drover might, the commission merchant received $1 \%$ or less. In addition, the commission merchant provided more services than the drover. The commission merchant reduced the costs of marketing and multiplied the classifications and species of animals a producer could market effectively. Historically, the drover only operated in the cattle trade. Railroads enabled the transport not only of cattle but also of sheep and hogs over long distances. Commission merchants happily accepted the task of marketing these livestock species as well.

Nonetheless, cattle dominated the trade receipts in Kansas City. The ratio between cattle, hogs, and sheep in total pounds shipped to Kansas City from 1871 to 1915 was 75:20:5. Huge numbers were involved after the turn of the century. An average of 2.7 million hogs, 2.2 million cattle, and 1.8 million sheep were shipped annually to Kansas City between 1906 and 1915 (Atkinson 1971). Unlike the drover, the commission merchant did not accept ownership of the animals. No one commission merchant could take title to the thousands of animals sent to the market daily; instead they minimized their investment risk by operating on consignment.

A single commission firm owned by A. J. Snider took 19,000 cattle off the grasslands of the Southwest in October 1885 and marketed them in Kansas City. Only a few days elapsed from the time the cattle were loaded onto a railcar to the time the ranchers received payment. In contrast, a drover of that time could trail only 3,000 cattle at once and had to spend a considerable amount of time moving them overland to market. Drovers easily succumbed to this sort of competition from the commission merchants. There was little or no protest from ranchers at the passing of the drover. Producers appreciated the lower costs and greater flexibility granted by the commission merchants during the initial phases of the organizational revolution in the livestock trade.

The ascent of the commission merchant is illustrated in the story of a west Texas cattleman named A. P. Bush. In 1877, Bush spent the entire 
summer in Kansas City and watched the daily telegraph reports from Chicago and St. Louis in an attempt to make the best decision as to when and where to market his cattle. Ironically, Bush used a commission merchant to sell his cattle even though he remained at the market all summer. He became aware that only the commission merchants knew the market well enough to fully exploit its trends (Hazlett 1995).

The early livestock commission merchants of Kansas City further sought ways of distinguishing themselves from their competitor, the drover. The telegraph was one such means. The commission merchants were quick to exploit its value on behalf of their customers. It was the first reliable source of price discovery. For the first time in the history of the animal trade, the telegraph instantly supplied information on price changes in Kansas City, Chicago, St. Louis, and Omaha. Commission merchants kept their customers in the countryside appraised of changing prices with regular market quotes in order to help them pick an advantageous marketing window for their stock. The prepaid telegram was the means by which this information was communicated.

The Texas Live Stock Journal printed on February 9, 1889 recorded the importance of one such prepaid telegram. Several days prior, the cattle market advanced from $15 \phi$ to $25 \phi$ /hundredweight. Simultaneously, several thousand telegrams quoting the price increase were issued from the Kansas City Stockyards. Producers holding cattle on the grasslands west of Kansas City loaded nearly 17,000 animals onto railcars and rushed them to market. As a result, the first to arrive profited from the information. In this way, the telegraph was just as revolutionary to the livestock trade as the railroad.

\section{A Day At The Stockyards}

Daily operations at the stockyards evolved into a highly ordered series of events. Cattle arriving at the stockyards were met by employees of the stockyard company and unloaded

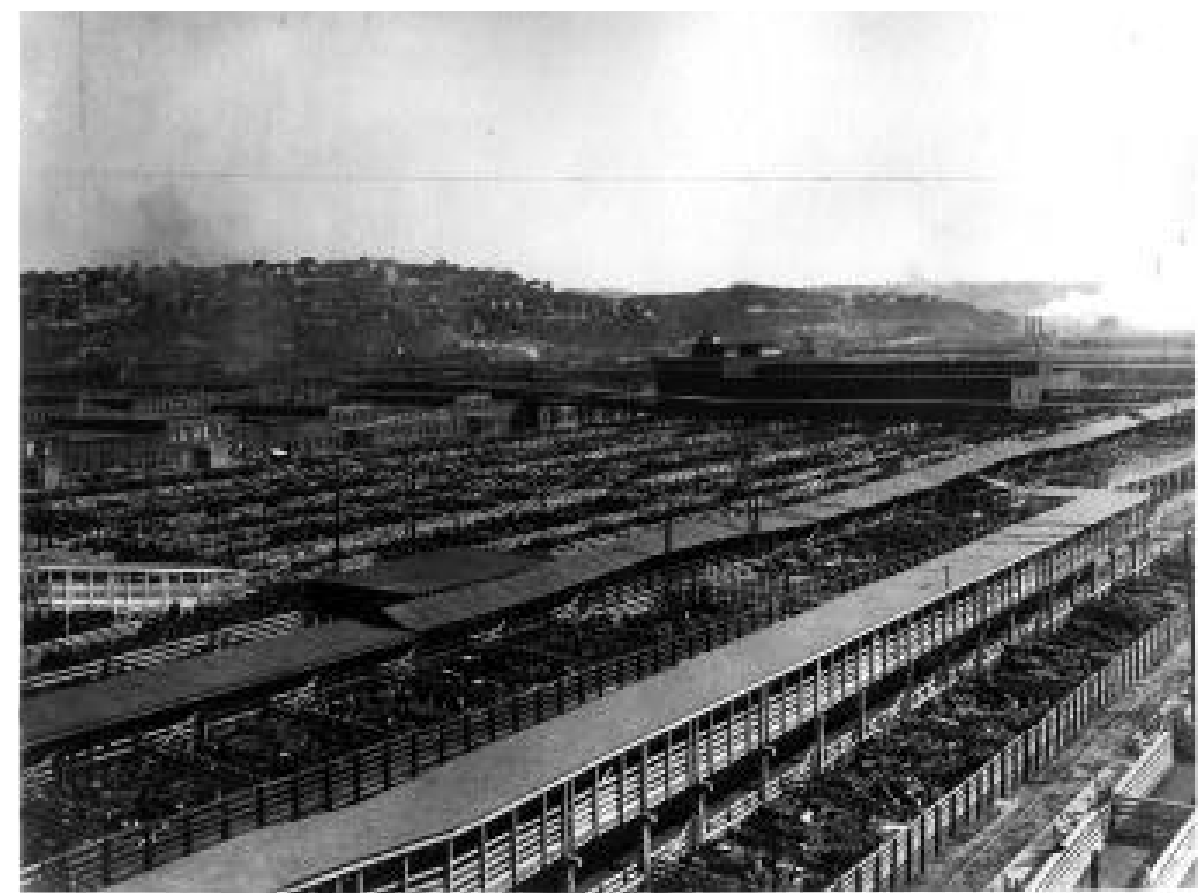

An aerial view of the cattle pens at the Kansas City Stockyards in the early $20^{\text {th }}$ century. Provided by the Kansas State Historical Society - Topeka, Kansas. Reprinted with permission.

from the railcars. Livestock were then delivered to the alleys and pens assigned to the commission firm that was designated by the owner to handle the sale. After that point, employees of the commission firm fed and watered the stock until they were sold. Editions of the Texas Live Stock Journal printed on February $6^{\text {th }}$ and March $13^{\text {th }} 1886$ printed fee scales for the stockyards. Feed charges at the Kansas City stockyards were $\$ 1 /$ bushel of hay and $75 \phi /$ bushel of corn. The yardage charge was $20 \phi /$ head/day for cattle, $8 \phi /$ head/day for hogs, and $5 \notin /$ head/day for sheep. These prices were substantially cheaper than at Chicago: $\$ 1.50 /$ bushel of hay and $\$ 1 /$ bushel of corn; and $25 \phi /$ head/day for cattle, $\$ 8 \not /$ head/day for hogs, and $8 \notin /$ head/day for sheep.

The morning after the livestock arrived, the commission merchant transacted business in the alleys and pens that housed his client's cattle. Packer buyers, order buyers, and cattle feeders rode horses through the alleys or walked along the catwalks constructed over the pens and made their selections. Contracts struck between the commission merchant and the buyers were private treaty affairs and were transacted orally. Many commission men kept the figures in their heads until they returned to the commission office in the exchange building.

Once terms of the sale were agreed upon, the livestock were herded to scales and weighed. There the first record of the transaction occurred when a scale ticket was attached to the bill of lading from the railroad. It was subsequently delivered to the stockyards company office. The buyer was then free to collect his purchase. The commission merchant received payment for the livestock at the stockyards company office. The stockyards company charged the commission firm for the rail freight and the yardage fees. The commission firm then paid the seller after deducting commission, freight, and yardage fees from the total sale price. This process initially took place 24 hours a day, 7 days a week (Hazlett 1995).

A large amount of money changed hands during the course of an average day at the Kansas City Stockyards Company, creating opportunities for 


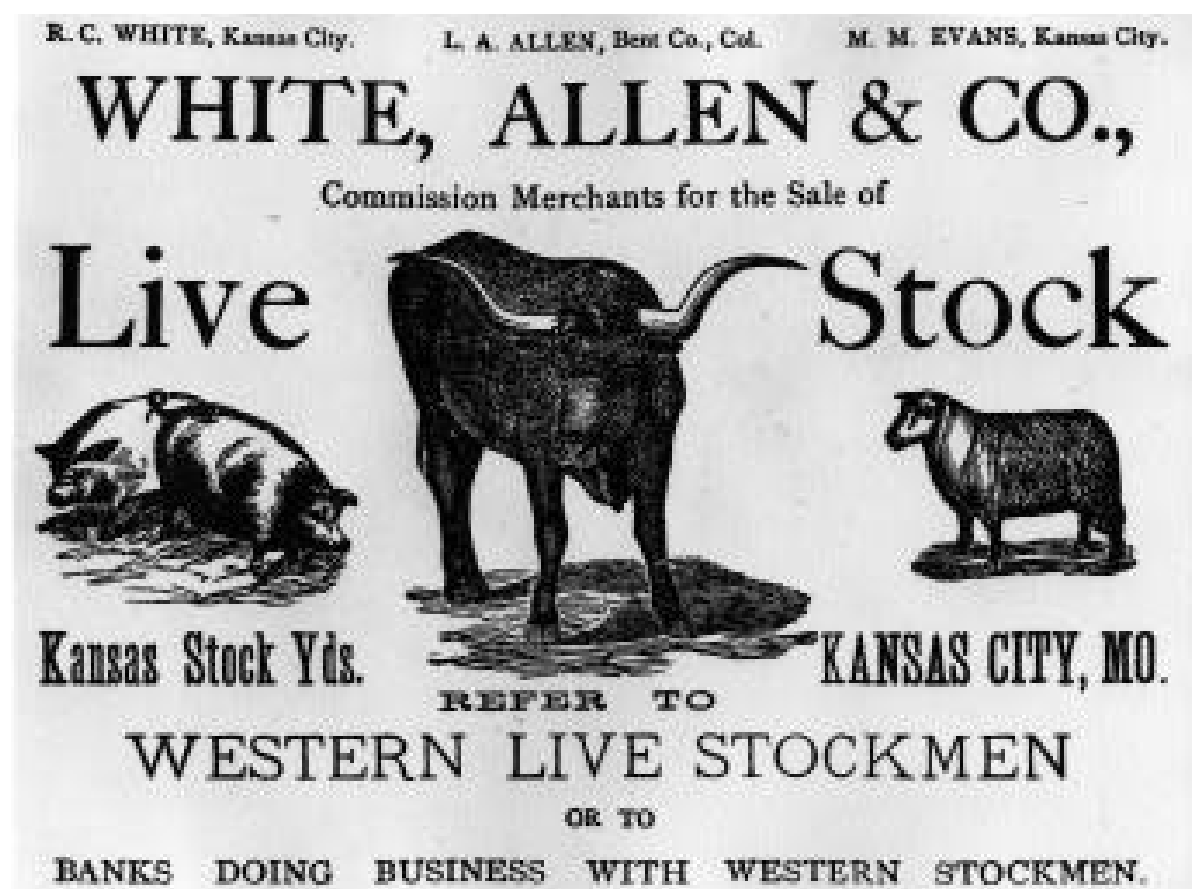

An early handbill advertising the commission services of White, Allen, and Company. Provided by the Kansas State Historical Society - Topeka, Kansas. Reprinted with permission.

both the financier and the cattleman. Kansas City area banks leapt at the opportunity to do business with patrons of the stockyards company. Many opened offices adjacent to the stockyards or within the stockyards building itself to handle the deposits of cattlemen. By the same turn, ranchers had the convenience of borrowing operating capital at the same banks. Kansas City bankers routinely took risks on cattle originating from all over the Southwest.

One such institution was the Emporia National Bank. It loaned $16 \%$ of all operating capital to ranchers in Roberts County Texas in 1900. Overall, Kansas City banks loaned $50 \%$ of the cattle money in the Texas panhandle in that year (Hazlett 1987). In making operating loans to ranchers who lived far from Kansas City, stockyard banks relied heavily on the commission merchant to judge the rancher's character and business acumen. Stockyard banks also depended upon the commission merchant to report on the location and disposition of any cattle under mortgage. In this way, the commission merchant became the critical link between the ranchers in capital poor areas of the West and the Kansas City banks.

Banks were not the only institutions to finance the new cattle trade. The Kansas City livestock commission merchants themselves provided much needed cash flow to ranchers. They often provided financial advances on consigned cattle and they learned quickly that they could direct more business to their firms by giving these advances. Soon it became customary for cattle owners to draw upon commission firms for at least a part of the purchase price of the animals they shipped (Hazlett 1995).

\section{National Markets Lead To National Animal Diseases}

It was inevitable that the freewheeling economic conditions attending the development of the national market in livestock would lead to controversy. Particularly in the frontier areas, local and federal governments were not a regulatory force prior to 1900 . That is, government agencies rarely imposed rules upon industry. It was in this laissez-faire trade environment that unique biological and ethical problems first challenged the national livestock trade.

The biological problem confronting the trade was an unintended consequence of a nation-wide transportation system. As livestock were moved by rail from the four corners of the country to the national markets of the Midwest, they brought with them their endemic diseases. Outbreaks of Texas fever, pleuro-pneumonia, hog cholera, and tuberculosis were only regional in scope prior to the era of rail transport. By 1883 , these diseases became national epidemics and the livestock markets in Kansas City and Chicago became focal points of disease transmission (Hazlett 1992).

The United States government was ill equipped to deal with the crisis. There was no stated policy on the control of animal diseases before 1884 , nor did any federal agency have executive power to deal with such a problem. Livestock producers demanded that the United States Department of Agriculture act during the epidemic outbreaks brought about by rail transport during 1883 . The government responded by creating the Animal Industry Bureau in 1884. This organization was given broad powers to identify and destroy diseased animals. It also had the power to quarantine any stockyards it determined to be infected (Smithcore 1963). The scope of this power directly threatened the livelihood of the livestock commission merchants.

Animal Industry Bureau veterinarians advocated shutting down all stockyards in 1884 when pleuro-pneumonia was diagnosed in Chicago; however, their views inspired little confidence among ranchers and commission merchants. Government veterinarians of the time were not held in high regard (Smithcore 1963). Other prominent veterinarians disputed the claim that pleuro-pneumonia was infectious. In their estimation, the disease could not be contracted in the stockyards. The commission merchants, closely fol- 
lowing the arguments of this faction of experts, acted in their own interest and opposed the closing of the stockyards by the Animal Industry Bureau. This dispute over disease control highlighted the need for the commission merchants to speak with one voice on subjects that affected their business (Hazlett 1992)

In response to the dispute with the Animal Industry Bureau over disease issues, the Chicago livestock commission merchants organized the Chicago Livestock Exchange in March of 1884. As an association, they successfully lobbied the U.S. congress to reduce financial appropriations to the Animal Industry Bureau and to sharply limit its executive powers over the stockyards. In effect, they won the right to regulate stockyards commerce privately, free from government interference (Hazlett 1987). The commission merchants of Kansas City faced similar pressures but resisted organizing as the Chicago merchants had. The Chicago Livestock Exchange had effectively quashed government attempts to regulate the livestock trade over animal disease issues. The need for the Kansas City merchants to form an organization of their own was not urgent from that perspective. The impetus behind development of a livestock exchange there came from a wholly different source; the cattlemen customers of the Kansas City stockyards.

\section{Unethical Behavior Also Plagued Stockyards}

While epidemic livestock diseases threatened the national livestock markets from without, unethical behavior by the commission merchants and packers threatened them from within. The volume and the anonymity common to the newly reorganized livestock trade made the sellers totally dependent on the integrity of their trading partners. That corrupt people would take advantage of what was essentially an honor system was unavoidable. Certain business practices of the commission merchants and the packers were begun in good faith but would later be routinely used to defraud sellers. Naturally, livestock producers were angry and sought justice.

Within the stockyards of Kansas City and Chicago, all contracts between buyers and sellers were oral. The integrity of the commission merchant was the only thing protecting livestock owners from fraud. It was not until the commission merchant rendered the bill of lading and the scale tickets for a given sale at the office of the stockyards company that there was an identifiable contract. It was a relatively easy matter for a dishonest commission merchant to falsify the account of the sale in order to collect a larger consignment fee than was agreed upon.

A Chicago commission merchant, J. S. McFarland, sold 66 heavy cattle for D.P. Taylor of Avoca, Iowa weighing $93,030 \mathrm{lbs}$ for $\$ 4.70$ per hundred. He returned to the seller only $\$ 4.60$ per hundred and pocketed the difference. An audit by the Chicago Livestock Exchange of McFarland's account books uncovered the fraud. He was immediately expelled from the exchange (Hazlett 1987). Kansas City, at the time, had no such mechanism to police its own merchants. Crimes like this, if discovered at all, were instead in the purview of local courts that were notoriously slow to prosecute offenders.

The telegraph was also subject to misuse. Some commission merchants, in an effort to encourage livestock sales during periods of low prices, purposefully misquoted the market in telegraphed price circulars that were widely distributed. The fact that the Kansas City Stockyards initially operated 24 hours per day, seven days per week encouraged this type of behavior. Some merchants conducted their business during the evening hours because fewer people were around the yards to report misdeeds. Adding to the deceit was that livestock shipped in on night trains were often sold before all the buyers appeared in the market during the day. It gave an unfair advantage to some buyers and suppressed competition for the seller's animals.
Unscrupulous livestock buyers were also a problem. Some were known to take advantage of the time lag between the oral contract and the delivery of payment. Deceitful buyers frequently denied agreements made with the commission merchant in the yards when the price of livestock declined during the day. A second problem encountered with livestock buyers was known in the trade as the dockage swindle. Hogs sold by the pound and were subject to a price dock by packer buyers. They docked $40 \mathrm{lbs}$ off the actual weight of a pregnant sow and $80 \mathrm{lbs}$ off of each castrated boar because the pork from these types of animals was viewed as tainted. The weight dock was imposed after the time of sale; the packers quickly learned that the dockage system was a convenient way to reduce the price they paid for hogs. Unfortunately, there was no way a farmer could appeal the dockage decision of the packer buyer (Hazlett 1992).

A hog trader named Z. W. Montague in a letter to Drovers Journal (August 12,1884 ) poignantly illustrated the graft inherent in the dockage system. Montague's commission agent sold his hogs early one morning but the hogs were not weighed and docked until late afternoon. During that day, the price of hogs declined $25 \%$ /hundredweight. Observing this price trend, the packer buyer warned the commission agent that Montague would have to take a big weight dock before payment was rendered. To make his actions less obvious to others in the stockyard, the packer buyer rushed the load of hogs out of the pen six or eight abreast and identified aloud each hog he viewed as imperfect. Montague was astonished at the number of dockages applied by the packer buyer. In his opinion, there was only one dockable hog in the lot but the packer buyer managed to reduce the price of that lot of hogs exactly $25 \phi$ /hundredweight from the high morning price to the low afternoon price (Hazlett 1987).

In principle, both hog traders and packers agreed that there was a legitimate dock for imperfect animals; 
however, it was clear that the packer buyers were using the so-called dockage swindle to control their costs. Volatility was inherent in the hog markets. Prices changed as much as $30 \%$ in one day. Packer buyers could easily lower the price of hogs bought early in the day by applying the dock late in the day. Customers of the stockyards noticed the applied dockage seemed fairer if hog prices went up during the day. It did not take long to figure out why; the buyers were manipulating prices (Hazlett 1987).

Several other business practices of the commission merchants, while inside the letter of the law, were ethically questionable. From the beginning of the commission trade, firms used a type of employee called a solicitor. Solicitors lived at locations remote from stockyards, most often close to a large resource of cattle. They usually held other influential jobs within their local livestock industries. Railroad agents and cattlemen's association representatives were the favored solicitors of the commission firms. Their job was to influence ranchers to consign stock to specific commission houses. In return, solicitors received half the consignment fee. Inside information provided by their solicitors gave a commission house a competitive edge. The fact that blatant conflicts of interest often occurred did not escape the notice of cattlemen. Solicitors became such a controversial part of the business that commission firms rarely identified them publicly. Furthermore, solicitors had little loyalty to any single commission firm; they frequently switched employers for more pay. In time, solicitors brought discredit upon the Kansas City market (Hazlett 1995).

\section{Independent Traders \& Speculators}

Independent livestock traders were common during the late $19^{\text {th }}$ century. Traders stayed in the stockyards at all times and made money principally by taking advantage of market volatility. Traders seldom held stock in their possession more than a few days.
Although not recognized as such, traders in the Kansas City stockyards were the allies of the producer and the enemies of the packer. Without these speculators in the yards, the packers could have exercised an even greater degree of control over the prices of livestock at critical times. Even so, not all speculating was positive.

A second questionable practice of the commission merchants was independent speculation by commission house employees. Employees were free to purchase livestock on their own private accounts in the hopes that prices would rise before resale. Although legal in practice, their speculating was ethically dubious. Commission house employees received discounts on yardage and feed at the Kansas City stockyards. They could afford to hold livestock there over longer periods, while waiting for a market upturn, than could a livestock producer. Inevitably, some poor quality stock came into the possession of commission house employees who traded on their own accounts. Unscrupulous agents could easily substitute their own inferior animals for a customer's high quality animals. The employee was required only to report the number of livestock sold; a few in ferior animals placed in a large load went undetected. Speculating by commission house employees rightfully caused deep resentment among livestock producers (Hazlett 1987).

The third ethical issue encountered at the Kansas City market involved consignment fees. Beginning prior to 1886 , commission firms began to rebate half of the consignment fee for especially large shipments of livestock. This practice became a useful means by which to win customers for a particular commission firm. Unfortunately, it escalated to the point of abuse. Vigorous competition made the commission business difficult to enter because the larger, wealthier firms could operate on narrow financial margins. They could afford to offer continuous commission rebates while the small, newer firms could not.
Four commission firms dominated the cattle trade prior to 1886 . A. J. Snider and Co. marketed $44 \%$ of the cattle sold through the Kansas City stockyards in October of 1885 . Three other firms accounted for $30 \%$ of cattle sold there during that month (Hazlett 1987). In an effort to eliminate competing commission houses, unscrupulous firms also advertised commission rates that were below operating costs. These merchants, in certain instances, made up their losses by falsifying the account of sale and defrauding their customers. Eventually these deeds were discovered (Hazlett 1992).

\section{Cattlemen Form A Voice}

Outcry by the nation's agriculturalists against the poorly handled animal disease epidemics and the unethical business practices of some commission merchants became vehement by 1885. Kansas City commission merchants again felt pressure to organize a regulatory exchange, as the Chicago market had in 1884 , but delayed it for two years. In 1886, powerful cattlemen's associations in the Southwest forced them to act. Organized as early as 1867 (i.e., the Bent County Colorado Cattleman's Association), these private associations organized and controlled their respective local cattle industries. Increasingly intolerant of all middlemen in the trade, they were determined to eliminate them entirely. To this end, the western cattlemen's associations collectively created the International Range Association in January of 1886 . The New Mexico Territorial Cattle Growers Association and the State Livestock Association of Texas organized it. They, in turn, invited cattlemen from other states, Mexico, and British Columbia to join (Hazlett 1987).

Believing that the Animal Industry Bureau would act too late to save western cattle herds from pleuro-pneumonia, the International Range Association established a quarantine of the West against livestock shipped from east of the Missouri river. Moreover, they developed a series of 
executive committees. One timed, adjusted, or regulated the shipments of cattle from different regions in order to prevent a surplus in the markets and to bypass the commission merchants. Another could summarily formulate quarantine regulations. Still another was charged to control stock thieves by prosecuting violators throughout the west. That committee also created a blacklist of cattle industry personnel they viewed as dishonest and forbade members from employing or cooperating with them (Hazlett 1987).

The activities of the International Range Association deeply disturbed the Kansas City livestock merchants. Especially concerning was the threat to bypass the commission firms; the association controlled enough cattle to bring that threat to fruition. The Kansas City merchants were forced to acknowledge that the livestock commission business had numerous problems. If no internal solutions were forthcoming, they felt certain that their critics would succeed in imposing controls from the outside. This was the stimulus that brought about the organization of the Kansas City Livestock Exchange in February 1886 (Hazlett 1992).

Over the course of the next 35 years, the Kansas City Livestock Exchange would become a model of self-regulation in American business. It would effectively police animal disease outbreaks and restore integrity to the livestock trade. Moreover, the exchange also democratized the commission business by giving all firms a voice in the regulatory process and preventing monopolistic business practices by the largest, wealthiest firms.

The International Range Association was not as durable; it only lasted two years. It and other cattle associations lacked effective power. State legislatures were usually unsympathetic and without them the associations could do very little. This fate forced cattlemen to accept the commission merchant's ideas about internal regulation (Hazlett 1987).
The author is an assistant professor, Department of Animal Sciences, University of Missouri - Columbia, Columbia, MO 65211.

To whom correspondence should be addressed

\section{References}

Atkinson, E. L. 1971. Kansas City's livestock trade and packing industry, 1870-1914. Ph.D. Dissertation. University of Kansas, Lawrence.

Hazlett, O. J. 1987. Regulation in the livestock trade: the origins and operations of the Kansas City Livestock Exchange 1886-1921. $\mathrm{Ph}$. D. Dissertation. Oklahoma State University, Stillwater.

Hazlett, O. J. 1992. Chaos and conspiracy: the Kansas City livestock trade. Kansas History 15(2):126-144.

Hazlett, O. J. 1995. Cattle marketing in the American Southwest. Kansas History 18(2):100-115.

Smithcore, J. F. 1963. The American Veterinary Profession: Its Background and Development. Iowa State University Press, Ames, IA.

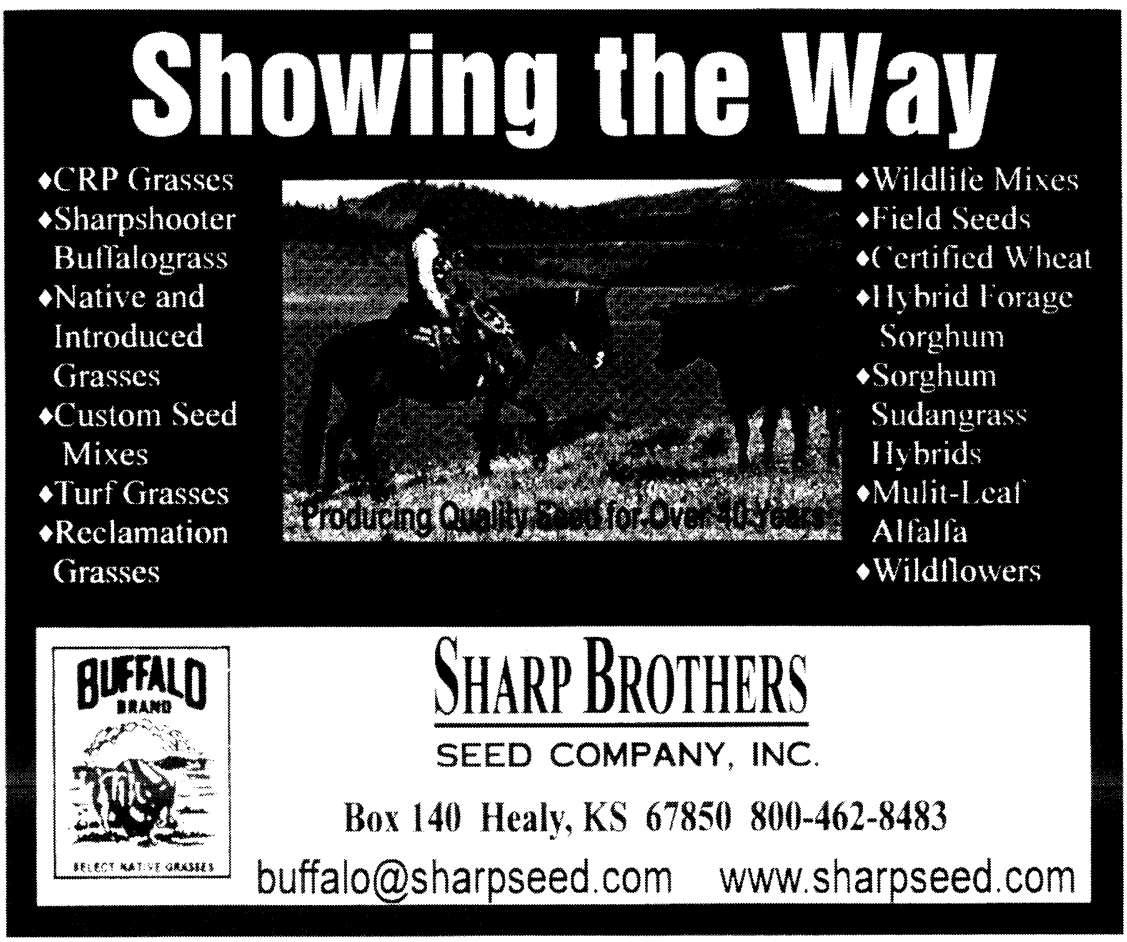




\section{Reform Of The Livestock Trade}

\section{The organization of the Kansas City Livestock Exchange helped restore integrity to livestock trade in the area.}

By KC Olson

To portray the organization of the Kansas City Livestock Exchange as resulting from a benign consensus among the commission merchants would be inaccurate. Certainly, two platforms around which the exchange was organized enjoyed wide approval among potential members: livestock disease control and restoring integrity to the Kansas City trade.

There was, however, dispute over the issue of setting standard consignment rates. In order for all commission firms to compete effectively, the policy of offering commission rebates had to be abolished. Two competing factions emerged over this issue. The free-trade faction consisted of well-es tablished, large commission houses. the fledgling organization.
They wanted to reserve the right to offer commission rebates as they saw fit. The regulator faction, made up of relatively new, small commission houses, opposed the free-trade faction. They wanted uniform consignment rates set for all commission houses.

In spite of these philosophical differences, organization of the Kansas City Livestock Exchange went forward. Members of the regulator faction were at the forefront of organizing the exchange; however, they invited all commission firms to join and all eventually accepted. They also invited livestock traders, packers, and the Kansas City Stockyards Company to provide insight into the operation of

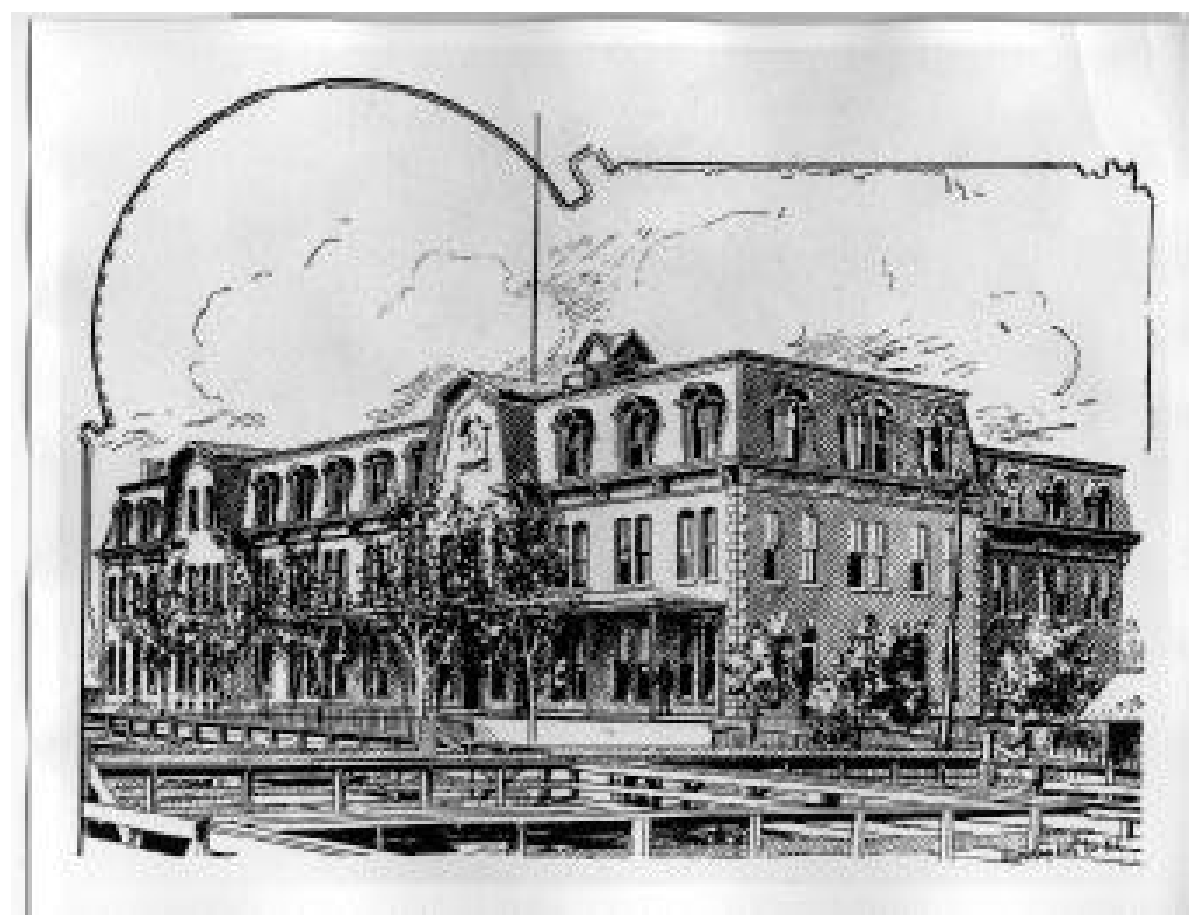

The Kansas City Livestock Exchange building, as it appeared in 1887. Provided by the Kansas State Historical Society - Topeka, Kansas. Reprinted with permission.
Historian O.J. Hazlett (1987) provides an excellent overview on the organization and operation of the Kansas City Livestock Exchange. The exchange was organized around a ninemember board of directors, a president, and four appointed committees that were tasked to accomplish specific goals of the exchange. Directors were elected for a 3-year term and the president for a 1-year term.

The Kansas City Stockyards Company and a consortium of local packers were allowed to appoint one representative each to the board of directors. Although the terms of service for these two positions were indefinite, the commission merchants always maintained control of the board. The board met a minimum of 12 times per year but could hold special sessions whenever necessary. Ten members of the Kansas City Livestock Exchange, by signing a petition, could force the directors to call a special meeting. Members also had the power of referendum over decisions made by the directors.

Initially, the board of directors appointed an executive committee, an arbitration committee, and an appeals committee. In 1899, they added an investigating and judiciary committee to prosecute rule-breakers within their own ranks. There were five members of the exchange on each committee, including one representative from the Kansas City Stockyards Company and one from the packer consortium.

A series of self-imposed taxes, fees, and fines were used to fund operations of the Kansas City Livestock Exchange. There were taxes levied upon each carload of livestock re- 


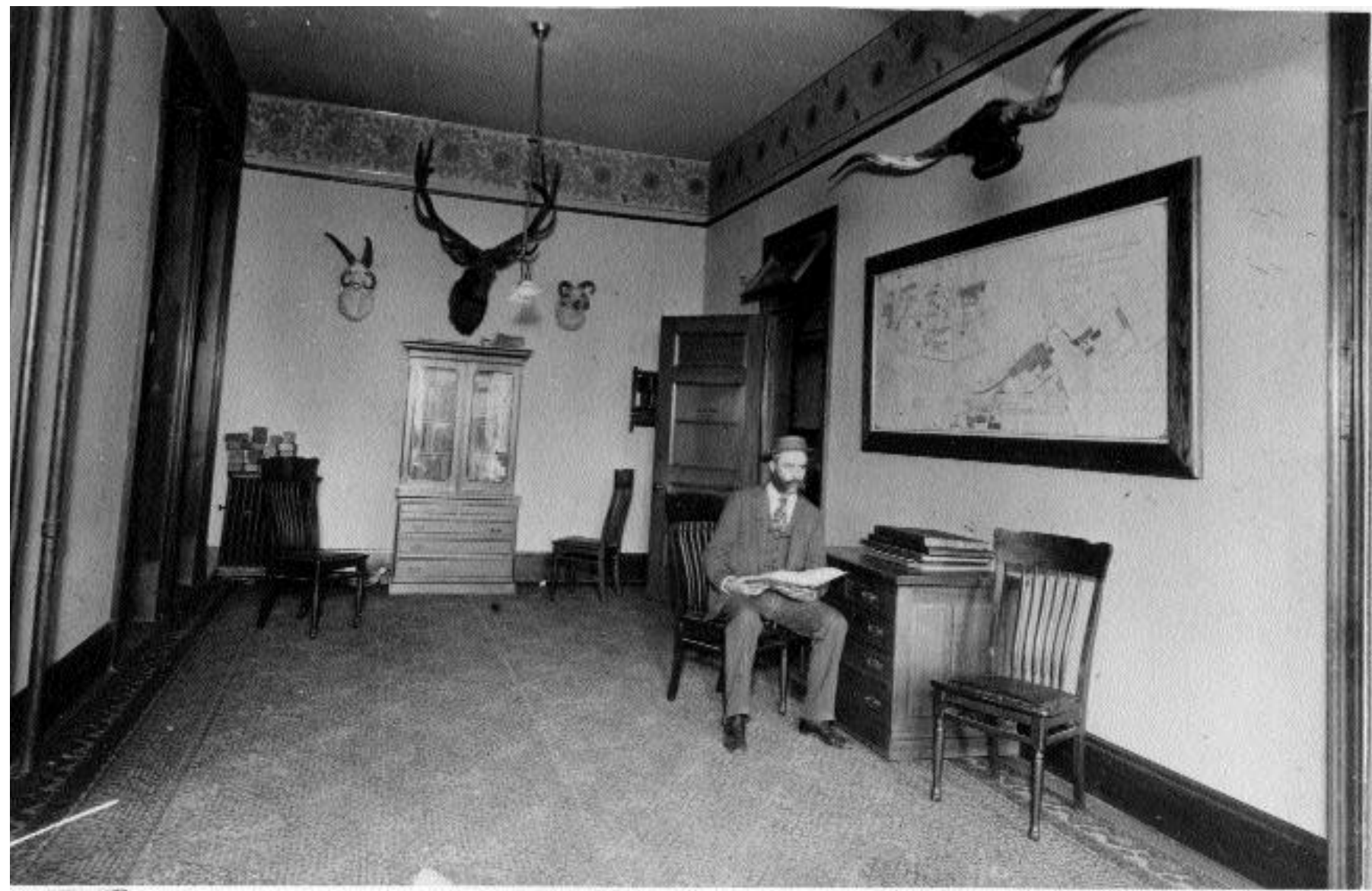

The general managers office in the Kansas City Livestock Exchange building, as it appeared in the late 19th century. Provided by the Kansas State Historical Society - Topeka, Kansas. Reprinted with permission.

ceived at the Kansas City yards, fees for membership and arbitration, and fines levied upon members for rule infractions. The exchange was relatively inexpensive to operate. In 1908, income to the exchange was $\$ 14,559.54$, while cash outlays totaled $\$ 12,028.54$. Sixty-three percent of this income was from rail car taxes, $4 \%$ from arbitration fees, $7 \%$ from membership dues, and $21 \%$ from fines levied against members.

The constitution of the Kansas City Livestock Exchange granted the board of directors the power to prosecute and discipline violators of the rules. The board of directors was empowered to fine, censure, suspend, or expel offending commission merchants; however, it could not discipline a member without itself convening a commercial trial. The accused were allowed to defend themselves but could not employ professional legal counsel. Refusal to appear before any committee or commercial court brought an automatic suspension from the exchange. Additionally, if a member sought injunction from any court of law against the exchange, the exchange considered their membership forfeited.

The rules of the exchange specifically forbade any member from taking commercial disputes into a court of law. Commission merchants were required to submit all commercial disputes to the arbitration committee of the exchange. Independent livestock traders, farmers, and ranchers could force a dispute into arbitration simply by notifying the board of directors. In the event that a customer was unsatisfied with the decision of the arbitration committee, the appeals committee would review the dispute. Decisions by the appeals committee were final and binding. Commission merchants who refused to pay an award ordered by either the arbitration or appeals committees guaranteed their expulsion from the exchange by the board of directors. The investigating and judiciary committee, by their charter, was supposed to prosecute rule violators aggressively. Even a rumor of impropriety was enough to precipitate an investigation. The committee was also responsible for presenting charges and evidence against accused exchange members during commercial trials.

\section{Reform Returned Prestige To Kansas City Yards}

Once the administrative and revenue gathering structures of the Kansas City Livestock Exchange had been determined, members set out to address the specific biological and ethical 
dilemmas that were facing the commission trade. To exercise control over the spread of livestock diseases, the executive committee hired public inspectors and placed one at each of the 12 scales located in the stockyards. The job of the inspector was to monitor all animals as they crossed the scales and to mark or quarantine any that were diseased, injured, or otherwise imperfect. The decision of an inspector could be appealed to a chief inspector in charge of adjudicating all disagreements. There was no appeal from the chief inspector's decision.

The inspectors hired by the exchange were not necessarily qualified to spot a diseased animal. Recognizing this, the U.S. congress passed legislation placing qualified veterinarians in all the major markets. These officials did not replace the exchange inspectors, but merely stationed themselves near the scales and watched for diseased animals while the exchange personnel monitored the remaining ones. The first government inspectors appeared at the Kansas City stockyards in 1894. The exchange initially opposed the presence of the government veterinarians on the grounds that they were redundant; however, that attitude changed over time. Soon the government veterinarians convinced the exchange members that their services were essential. In 1920, when the appropriations for government stockyard inspectors were drastically reduced, the exchange hired their own veterinarians to serve that function.

The public inspectors also provided the solution for the dockage swindle. The exchange board of directors immediately removed the packer-paid hog docker from the stockyards and replaced them with their own inspection personnel. Each inspector was paid by the exchange and favored neither the producer nor the packer. The fact that the decision of an inspector could be appealed was well received by livestock producers and traders in particular. The entire inspection system was surprisingly effective throughout the life of the exchange.
The exchange board of directors acted quickly to eliminate fraud from the Kansas City commission trade. All member firms of the exchange were required to provide written authorization empowering the board of directors to audit their account books and telegraph messages as needed. The threat of a surprise audit made it very difficult for the commission merchants to falsify sales accounts. As a result, livestock producers and traders had greater assurance of receiving all the money that was their due. Any merchant found guilty of fraud during a commercial trial was expelled from the exchange.

Equally important was the board's ability to examine all market-related telegraph traffic. Members of the exchange who telegraphed false market reports in order to stimulate livestock shipments during periods of low prices would invariably be caught. The board also limited market quotes by commission firms to only those sales that the firm itself had transacted.

The exchange reduced other opportunities for fraud by redefining the role of the commission house solicitor and regulating business hours. The exchange forbade commission firms to pay solicitors based on a percentage of consignment fees; moreover, they required solicitors to register with the secretary of the exchange by name and address. The exchange also required all solicitors to be employed on a full time basis; no longer could a solicitor also be a railroad livestock agent or a cattlemen's association representative. In imposing restrictions on the nature of the solicitor's position, opportunities for conflict of interest in livestock sales largely disappeared.

The exchange also limited the time the stockyards and the commission firms remained open to transact sales to daylight hours. This policy ensured that every seller would be able to market their livestock with maximum price competition among buyers. It also made the commission business more public; it became nearly impossible to carry out a misdeed in the stockyards without someone else witnessing it.

The Kansas City Livestock Exchange recognized early that livestock producers and traders had no security against crooked transactions or insolvency of the commission firms. To remedy the situation, the exchange forced commission firms to put up a bond to ensure that merchants returned all monies to customers who sold livestock on consignment. Few businesses thought in terms of a surety bond before the turn of the $20^{\text {th }}$ century but the Kansas City Livestock Exchange pioneered its use as early as 1893. The price of membership in the exchange could also be used as a form of surety bond. Any commission merchant caught defrauding a customer was expelled from the exchange; that merchant's membership was then sold and the proceeds were used to help reimburse the defrauded customer.

Despite these measures, fraud and insolvency continued to be a problem. In 1912, the exchange created a collection agency tasked to verify that all buyers had the necessary cash to complete their proposed transactions. Later, the exchange provided a blanket bond for all commission merchants. The exchange first used the blanket bond to reimburse customers who lost money as a result of the insolvency of some commission firms during the economic panic of 1919.

The final internal reform enacted by the Kansas City Livestock Exchange was to set uniform consignment rates: $50 \phi /$ head for cattle and $10 \phi$ for hogs or sheep. Later, an equivalent charge of $\$ 12 /$ railcar was established for cattle. Similarly, \$6/single-deck railcar or $\$ 10 /$ double-deck railcar was assessed for hogs and sheep.

The free-trade faction within the exchange membership was furious, as were some of their larger customers; however, the members belonging to the regulator faction greatly outnumbered them and, thus, controlled the vote. Simply publishing standard consignment fees did not guarantee their enforcement. Firms belonging to the 
free trade faction initially ignored the rules governing consignment fees. Free-trader firms openly rebated commissions on large shipments of livestock. To obtain evidence of these violations, the exchange hired detectives to board stock trains moving in and out of the Southwest. When evidence was found to confirm that rebates had been offered to certain customers, the exchange board of directors levied heavy fines against the offenders. Failure to pay resulted in immediate expulsion from the exchange and the Kansas City Stockyards.

The Kansas City Livestock Exchange set an important precedent in the commercial trials of commission firms who violated the rules barring consignment fee rebates. It asserted successfully the right to regulate commission rates and to discipline violators of the rules; it also prevented the financially powerful commission firms from undermining the functions of the exchange. The only exceptions made to the consignment fee rules were for other livestock markets. It permitted commission rebates to merchants at Omaha, St. Joseph, Denver, Wichita, East St. Louis, St. Louis, Chicago,
Pueblo, Sioux City, Milwaukee, and Fort Worth on stock forwarded to Kansas City from those markets.

As Kansas City Livestock Exchange grew in prestige, it began to exert an influence on interstate commerce. It sought, for example, to get new rail mileage into Kansas City. In 1886, the year the exchange organized, ten railroads funneled traffic into Kansas City. By 1893, they numbered 16 . The number of rail cars received in 1893 was 27,483 more than in 1886 ; over half the increase came from the new railroad mileage.

The exchange also used its influence to affect national agricultural policy. In 1892, the federal government ordered cattlemen out of the Cherokee Strip grazing allotment in Indian Territory by October. The exchange directors sent a letter to Agriculture Commissioner J. M. Rusk condemning the decision. The letter explained that the strip contained from 125,000 to 170,000 cattle; expulsion of all of these cattle would glut the Kansas City market. Cattlemen in that area had no other market option inasmuch as Kansas, Colorado, and Texas forbade the movement of cattle into their grazing lands before December 1 due to fears of an outbreak of Texas fever. The exchange directors, moreover, argued that if Cherokee Strip cattlemen were forced to dump their animals on the Kansas City market, it would cause a price depression for all cattlemen in the southwest. Another mitigating factor was that the summer had been unusually dry in Indian Territory resulting in a rather sparse forage supply. This meant that the cattle there were thin and not readily marketable. The petition of the exchange met with success. The government delayed the execution of the order by two months.

The author is an assistant professor, Department of Animal Sciences, University of Missouri-Columbia, Columbia, $M O$ 65211, to whom correspondence should be addressed

\section{References}

Hazlett, O. J. 1987. Regulation in the livestock trade: the origins and operations of the Kansas City Livestock Exchange 1886-1921. Ph. D. Dissertation. Oklahoma State University, Stillwater. 


\title{
Regulation Of The Livestock Trade
}

\section{Private regulation of the livestock trade by the Kansas City Livestock Exchange was a success.}

\author{
By KC Olson
}

One of the most significant sidebars to the organization of livestock exchanges in the $19^{\text {th }}$ century was establishment of the right of private business associations to regulate trade. The livestock market at Kansas City grew from a local concern in the 1860 s to national trading center in the $1880 \mathrm{~s}$. The volume and anonymity this brought to the business forced participants to innovate new trading methods. New trading methods, in turn, gave rise to a need for some system of administrating disputes in a fair and expeditious manner. The commission merchants were fearful of government influence in the livestock trade, therefore they elected for self-regulation over regulation by the state when the Kansas City Livestock Exchange was organized. Cattlemen, by their subsequent ambivalence toward the new system, tacitly lent support to the principals of self-regulation (Hazlett, 1987).

While a few historical precedents existed, the move toward self-regulation was bold. In the absence of strong positive government, the exchange essentially became a regulatory agency that promoted democratization of the trade rather than consolidation. Instead of following the pattern of industrial corporations that concentrated economic power into the hands of a few, the Kansas City Livestock Exchange decentralized power by encouraging widespread participation from its membership. The major functions of the Kansas City Livestock Exchange were to make rules, arbitrate disputes, and police the conduct of the commission merchants. From
1886 to 1921 , it performed all the functions of a regulatory agency and demonstrated that is was possible to have regulation in a free economy without the heavy hand of government (Hazlett 1992).

In organizing a commercial exchange, the Kansas City commission merchants assumed certain rights from the government and its constituency. They assumed the right to organize their trade, to put a stop to anarchy, and to promote uniformity in business conduct. They also assumed the right to set commission rates for all livestock consigned to the Kansas City market. Furthermore, the exchange assumed the right to settle business disputes outside the normal judicial system (Hazlett 1987).

Nineteenth Century political commentator Edwin Snyder (1892) begged the question as to why the livestock industry allowed a voluntary association of less than 200 men to dictate to thousands of livestock producers the terms upon which their animals were sold. Historians later provided the answer. J. W. Hurst (1956) wrote that under a federal constitution committed to limited government, Americans routinely loaned the organized force of the community to private planners. Furthermore, the courts sustained the rights of these planners to act.

In the course of American history, state governments developed a narrowly defined view of their own power (Lurie 1979). This limitedpower view of government paved the way for private associations like the Chicago Board of Trade. The state of Illinois delegated to the Chicago
Board of Trade the right to regulate the grain trade through a corporate charter. The Kansas City merchants followed the Chicago example in organizing an exchange in 1886 but without applying for a corporate charter. With no stipulated authority from government, they simply assumed they had the right to regulate the livestock trade of the Southwest as an unincorporated private association (Hazlett 1987).

In retrospect, legal experts have expressed amazement at the audacity and breadth of power exercised by the Kansas City Livestock Exchange. The exchange determined who could and could not be a commission merchant; it conducted commercial courts outside the county or district courts; it fined members enormous sums of money for rule violations. Members could be summoned before the exchange board of directors and investigated upon a mere rumor of impropriety. The board even used anonymous witnesses to convict members and no attorney for the accused could appear in the commercial courtroom (Hazlett 1992).

A convenience of geography was perhaps an important reason why the exchange was able to conduct its business relatively free of government interference. The state legislature in Kansas was fairly hostile toward the Kansas City commission merchants. At times, it attempted to pass laws that imposed on the autonomy of the exchange. Unfortunately for the Topeka politicians, the exchange building was situated exactly on the KansasMissouri state line within the stock- 
yards. When necessary, meetings of the exchange membership were simply moved to the Missouri side of the exchange building, making it convenient to ignore Kansas law.

The Missouri legislature rarely interfered with the operation of the exchange and reportedly even encouraged the rebellion against Topeka. In spite of the seemingly high-handed management style of the exchange, all of its activities were found to be consistent with the trade rules of the time. The courts sustained the right of the Kansas City Livestock Exchange to regulate its trade in cases brought before state supreme courts in 1889 and 1906. The Packers and Stockyards Act of 1921 ended that grant of power (Hazlett 1987).

\section{Challenging The Exchange's Power}

Prior to 1921 , there were few serious challenges to the regulatory power of the Kansas City Livestock Exchange. Historian O.J. Hazlett (1992) nonetheless documented the events surrounding one such challenge that poignantly depicted the decisiveness and flair that was characteristic of the exchange.

By 1889 , a number of individuals belonging to the free-trade faction decided that they had borne enough of the exchange's presumptions of regulation and determined to take action. They formed a new business venture, the American Livestock Commission Company (ALCC), designed to weaken and eventually destroy the commercial and political influence of the exchange. The ALCC was a thinly disguised attempt to return to the nonregulated environment that had existed prior to 1886 . Its charter made it plain that the ALCC would ignore the norebate rules of the exchange and use the Wyandotte County (Kansas) district court and the Kansas legislature to try and force the exchange out of business. Anticipating opposition from the Kansas City exchange, the directors of the firm incorporated the ALCC in Illinois.
According to Hazlett (1992), most historians have interpreted the ALCC as a part of the late $19^{\text {th }}$ century cooperative crusade. In fact, it attempted to portray itself as a farmer's alliance in order to appeal to the populist legislature in Topeka. The reality was that the ALCC was spawned by large cattlemen from the southwest and not agrarian crusaders, although Kansas family-farmers did later lend it support. In spite of this alliance connection, the officers and managers of the ALCC were not poor farmers; they were old-style Kansas City free traders in a new guise. W. F. Peters was the only member of the ALCC's management team who was not a large dealer in cattle; he was a commission merchant. The ALCC needed an agent, like Peters, who was already a member of the Kansas City Livestock Exchange so that it could avoid being rejected for exchange membership.
The ALCC threatened to boycott the Kansas City exchange if the commission firms and packinghouses discriminated against it. The new organization promised instead to ship their cattle to Chicago, relying on a contract with every stockholder that bound them to transact all of their business through the cooperative. By the terms of its charter, the ALCC would rebate $65 \%$ of net earnings back to consignors in proportion to the number of cattle that each marketed through ALCC. Remaining earnings were to be distributed among the stockholders in proportion to the number of shares each held.

Members of the ALCC controlled enough cattle that the Kansas City Livestock Exchange perceived them as a very real threat. If successful, the ALCC would vastly undercut the services of the exchange members and drive most of them out of business.

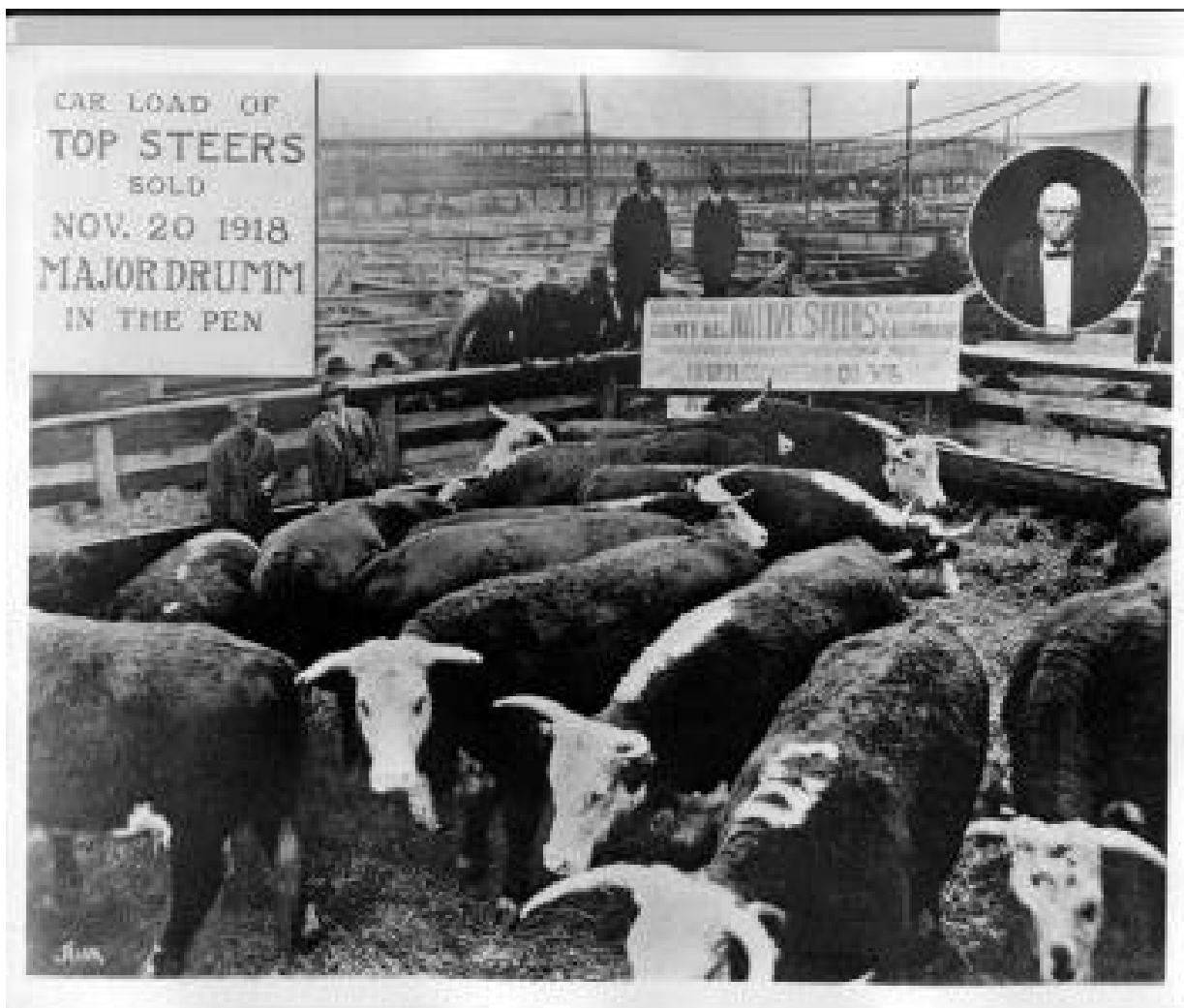

Cattle sold by Major Andrew Drumm at the Kansas City Stockyards on behalf of E. R. Lehmann of Eureka, Kansas. Drumm (inset) was a prominent member of the free-trade fac tion and a promoter of the American Livestock Commission Company. Provided by the Kansas State Historical Society - Topeka, Kansas. Reprinted with permission. 


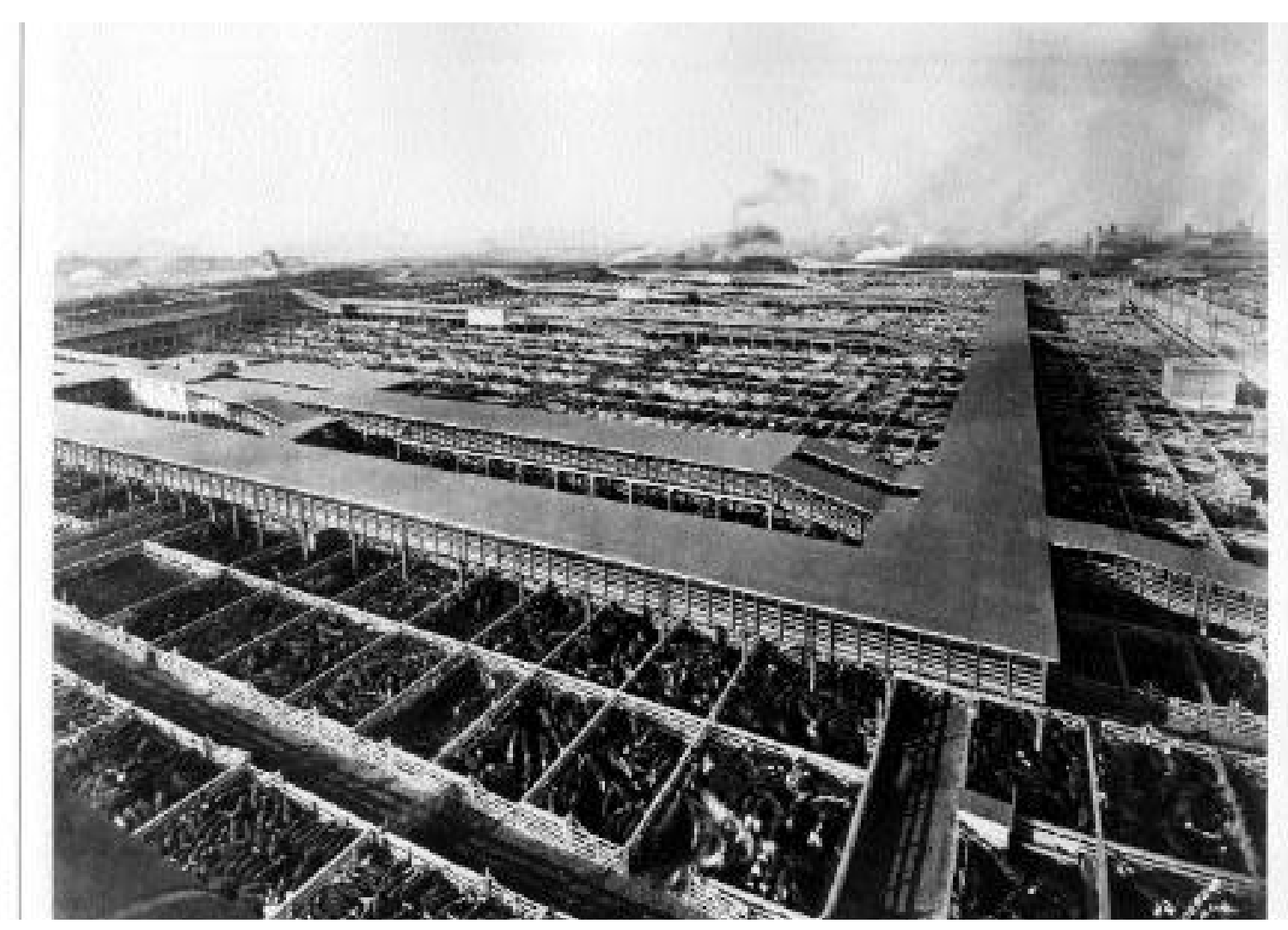

The Kansas City Stockyards, shown here at the height of its commercial prestige, closed in 1988 after 120 years of operation. Provided by the Kansas State Historical Society - Topeka, Kansas. Reprinted with permission.

Furthermore, the authority of the exchange would be undermined to the point of making it a laughing stock. The board of the Kansas City Livestock Exchange resolved to take action.

On June 11, 1890, the board notified the ALCC that charges had been filed against it for violating rules on commission rebates. Upon receipt of the charges, the ALCC sought the intervention of the Kansas legislature. Eli Titus, general manager of the ALCC, had enough influence that the legislature of 1891, which was largely controlled by the Populist Party, passed the Roe Bill. The bill declared the regulation of commissions on the sale of livestock in the state of Kansas unlawful, and thus, outlawed the Kansas City Livestock Exchange.

In response, the board of directors of the exchange revoked the membership of the ALCC, citing rules against seeking legal injunctions against the exchange. They also expelled all members of the exchange associated with the cooperative. The board stood firmly on the Missouri side of the exchange building and insolently declared that they would have nothing to do with the Roe Bill or with any laws enacted by the Kansas legislature. They further adopted a new rule that gave them a new disciplinary power over members: the authority to black ball. The black ball was immediately invoked against the ALCC. Previously the board could do nothing more than refuse to inspect any of the offending firm's animals at the Kansas City stockyards. Now it could prevent commission merchants, traders, packers, and railroads at the Kansas City stockyards from doing business with an offending firm by threatening a boycott. The implementation of the black ball rule against the ALCC effectively shut it out of the Kansas City market. No packer would buy its livestock and no trader would buy its animals for speculation.

In retaliation, the ALCC sought an injunction from the Illinois Supreme
Court against the Kansas City Livestock Exchange to prevent the expulsion. The Illinois court ruled in favor of the exchange on October 31, 1892. The opinion of the court was that the exchange had the right to regulate their own memberships, which included expulsion. The court did, however, concede that there was a strong basis for declaring the stockyards a public market, a fact that would make private regulation impossible under federal law. Nevertheless, the court declared that until the U.S. congress specifically declared that the stockyards were public markets, the exchanges had the right to regulate the livestock trade.

The ALCC never recovered from its challenge of the Kansas City Livestock Exchange. The forces of order defeated the advocates of laissez-faire business policy with ease and the exchange regulated the commission trade in Kansas City for another 32 years without interference. 


\section{Livestock Trade in the $20^{\text {th }}$ Century}

The pervasive influence of the Kansas City Livestock Exchange on the national livestock economy lasted until 1918. During the early $20^{\text {th }}$ century, packers began constructing private stockyards and again went into the countryside to purchase livestock directly from producers. This practice effectively bypassed the Kansas City stockyards and the regulation of the Kansas City Livestock Exchange. Merchants of the exchange were not allowed access to packer-owned stockyards to either buy or sell livestock. Additionally, competing markets in Denver, Oklahoma City, and Fort Worth began to circumvent the flow of cattle away from Kansas City (Hazlett 1987).

The development of irrigation on the Great Plains brought large-scale feed grain production to the region. Feedlots soon followed and cattle finishing began in earnest. Consequently, packers moved west to be near this new supply of finished cattle and much of the livestock industry shifted out of the Corn Belt and onto the Great Plains. By the mid-1980s, packers within a 250-mile radius of Garden City, Kansas slaughtered 4 of every 10 cattle in the U.S. (Hazlett, 1995).

The invention of the motor truck brought a second organizational revolution to the livestock trade by way of its application to livestock transport. The use of trucks encouraged the trend of selling directly to packers by increasing market flexibility of livestock producers. They were no longer bound to the railroad. The motor truck also spawned new marketing methods. As the trade continued to decentralize during the 1940s and 1950s, livestock auctions emerged on the Great Plains (Hazlett 1987). One of the first such livestock auctions was developed by Roy Sturtevant at Brookfield Missouri. As a regular customer of the stockyards at Kansas City, St. Joseph, and Chicago, Mr. Sturtevant was well acquainted with other people involved in the livestock trade. In 1930, he began to invite these people to Brookfield to bid on the livestock raised by local farmers. Later the bid process evolved into a formal auction (Dedrick 2001).

Several other events helped precipitate a general decline in the functionality of a centralized livestock trade. In the early $20^{\text {th }}$ century, a flourish of cooperative livestock shipping organizations began to organize. The first cooperative shipping associations were the cattlemen's associations in the late 1860s and early 1870s. Restricted market access during these early years forced cattle raisers to cooperate with one another. They achieved a degree of success by winning concessions from the railroads on freight rates because of the large number of cattle they represented. Despite these early precedents, cooperative shipping associations only organized on a large scale after the turn of the century.

Figures from Missouri clearly illustrated the popularity of this phenomenon. In 1921, there were 275 cooperative shipping associations in the state. The Missouri Farm Management Association organized a livestock-shipping club in Boone County and saved $\$ 84$ dollars on the first carload of animals sent to market. As important, the members reported, was that the local livestock speculators were forced to increase their bid prices to remain competitive. Shipping associations also enabled a higher return to the producer because livestock were sorted and graded before they were loaded onto market-bound trains. Livestock of similar grades, weights, and types brought higher prices on the market; by sorting and grading cattle themselves, producers instead of the livestock speculator could reap the associated financial benefits. The shipping organizations were short-lived, not because the farmers lost the cooperative faith but because the motor truck rendered them less competitive. Organizations that sprang up within trucking distance of the livestock markets of Kansas City, St. Joseph or St. Louis soon disbanded. Farmers preferred instead to truck their own livestock to market (Hazlett 1987).

On August 15, 1921, the U.S. Congress passed the Packers and Stockyards Act, which declared the major stockyards of the nation to be public markets. The American Farm Bureau and the National Farmers Union, groups that had lost confidence in the free market and wanted interference from the federal level, lobbied for this new legislation. Beginning in the 1920 s, a federal bureaucracy assumed the function of a regulatory force in the stockyards. Ironically, it employed the system of operation already institutionalized by the livestock exchanges. It supervised the setting of commission rates, regulated the membership, disciplined commission merchants and traders, and conducted audits, all at taxpayer expense. The new bureaucracy innovated very little beyond what the exchange had implemented over the previous 35 years with two exceptions: they allowed the cooperative commission firms back into the stockyards and they allowed livestock traders and livestock producers direct input into the operations of the public market (Hazlett 1987, 1992).

According to O.J. Hazlett (1987), economists have generally agreed that the Packers and Stockyards Act was a failure. This assessment stems from the fact that the packers escaped regulation under the statute until 1932 through lengthy litigation in the courts. Furthermore, the motor truck eventually made federal regulation of the stockyards meaningless. As the livestock trade decentralized, the marketing of livestock bypassed the major stockyards. Still, the act brought to a close an era of private regulation in the livestock trade. The Kansas City stockyards closed in 1988 after almost 120 years of operation (Hazlett 1995). 


\section{Conclusions}

Conspicuously lacking in historical accounts of our Western heritage are explanations of how and why the livestock business in the U.S. evolved as it did. A perceived lack of romance may have discouraged some from searching the livestock exchanges, stockyards and packinghouses for historical perspective. These were a symbol of industrialization in the American West and may not have fit into the idyllic image sought by historians (Hazlett 1987). There is much, however, in the accounts of these institutions to enlighten the modern-day agriculturalist.

During the $19^{\text {th }}$ century, the livestock commission merchants were a new economic institution born of innovations in transportation and communication. Commission merchants marketed livestock in a faster and more efficient manner than had their predecessor, the drover. They also became a source of operating capital for ranchers in the capital poor areas of the west. In some areas that ranged as high as $90 \%$ of all funds executed. It can be concluded that $19^{\text {th }}$ century ranchers in parts of the West could not have operated without the financial aid of the commission merchants (Hazlett 1995).

In particular, the rise of livestock exchanges fundamentally altered livestock marketing in the American Southwest. The Chicago and Kansas City livestock exchanges organized within two years of each other; however, the precise issues that sparked organization were different. Railroads carried livestock farther and faster than ever before to competitive urban markets. They also carried animal diseases that reached epidemic proportions by the mid-1880s. The search for a solution to the disease problem eventually prompted the organization of the Chicago Livestock Exchange. The anonymous nature of the new marketplace permitted unscrupulous buyers and sellers to flourish in the stockyards. There was no authority in the marketplace to administer the trade and correct abuses. This lack of regulation caused the organization of the Kansas City Livestock Exchange (Hazlett 1987).

The regulatory efforts of the Kansas City Livestock Exchange went far beyond the expectations of livestock producers. The exchange increased productivity by coordinating the activities of the railroads and the stockyards. It acted as a lobbying force, pressuring national government to modify its decrees. The exchange also reformed aspects of the trade little understood by outsiders. It recognized that unless market information and business hours were controlled, the activities of unscrupulous livestock commission merchants would discredit the Kansas City market. It even assumed the power to audit the books of commission merchants against their will in an effort to insure that livestock producers and traders received a correct return of funds. Finally, the exchange pioneered the concept of a surety bond to protect customers from fraud and insolvency (Hazlett 1992).

While some industries concentrated into a few large firms, the Kansas City Livestock Exchange decentralized the trade and enabled commission firms to remain small enterprises. Unlike most private associations, labor unions, and industrial corporations, the exchange did not become oligopolistic. No one interest group in the Kansas City market dominated the organization, neither the packers, nor the stockyards company, nor the large commission houses. Since the exchange effectively eliminated the domination of the larger commission houses, entrance into the trade was easier. Even traders and producers had access to the exchange. They refused to attend the initial organizational sessions but their absence did not mean they were powerless. That commission charges for cattle did not change for 36 years was testimony to their influence over the Kansas City Livestock Exchange (Hazlett 1987).

The Kansas City market reached its peak of influence in 1918 when cattle receipts totaled approximately 3 million dollars. From 1886 to 1921, the Kansas City Livestock Exchange assumed and responsibly executed regulatory power over the livestock trade of the Southwest on behalf of the government and its constituency. The Packers and Stockyards Act of 1921 ended that grant of power (Hazlett 1992).

The author is an assistant professor, Department of Animal Sciences, University of Missouri - Columbia, Columbia, $\mathrm{MO}$ 65211, to whom correspondence should be addressed

\section{References}

Dedrick, D. 2001. Personal Communication.

Hazlett, O. J. 1987. Regulation in the livestock trade: the origins and operations of the Kansas City Livestock Exchange 1886-1921. Ph. D. Dissertation. Oklahoma State University, Stillwater.

Hazlett, O. J. 1992. Chaos and conspiracy: the Kansas City livestock trade. Kansas History 15(2):126-144.

Hazlett, O. J. 1995. Cattle marketing in the American Southwest. Kansas History 18(2):100-115.

Hurst, J. W. 1956. Law and the Conditions of Freedom in the Nineteenth Century United States. University of Wisconsin Press. Madison, WI.

Lurie, J. 1979. The Chicago Board of Trade, 1859 - 1905: The Dynamics of Self Regulation. University of Illinois Press, Urbana, IL.

Snyder, E. 1892. Livestock markets of Kansas. In: Kansas State Board of Agriculture, Quarterly Report, March 1892. Hamilton Printing Co., Topeka, KS. 


\title{
First In A Series
}

\section{Charting Our Changing Course}

\section{Society will play an increasing role in the use and management of the world's rangelands.}

\author{
By Urs P. Kreuter and Michael P. Schellenberg
}

Editor's Note: The International Affairs Committee sponsored a sympo sium entitled "Rangeland Professionals and Society: Future Directions" at the 2001 annual SRM meeting in Kona, Hawaii. From those presentations, a se ries of articles will be published in Rangelands over the next six months highlighting perspectives on rangelands from around the world. The editors and authors wish to thank Dow AgroSciences of Indianapolis, Indiana, for a grant made in support of the symposium.

As human populations have grown, societal values and uses of both public and private rangelands have shifted. In developed countries, increasing urbanization and declining returns from livestock have resulted in a growing interest in the recreational attributes, ecotourism potential and non-agricultural uses of rangelands rather than their agricultural attributes. By contrast, in many developing countries, rapid population growth coupled with adverse economic conditions has led to accelerated transformation of rangelands for agricultural production.

Contrasting with these changes there is widespread public perception that our profession focuses exclusively on livestock production despite the grow- ing diversity of disciplines represented by rangeland professionals.

A 1998 survey of members and nonmembers of the Texas Section of the Society for Range Management, found that the term "rangeland" conjured images of cows and grass in the overwhelming majority of both groups (Hart and Rollins 1999). Both members and non-members also predominantly saw livestock grazing as the most important issue affecting Texas rangelands and, in general, considered current rangeland condition to be worse than historical conditions.

In the face of changing societal demands for rangelands, such stereotypic views are negatively affecting the perceived ability of our profession to contribute in the future management of rangeland ecosystems and their resources. The consequences of such negative perceptions include a decline in professional career opportunities for rangeland specialists in public agencies, a decrease in public support for rangeland-related research, a reduction in contributions to rangeland journals and a drop in the membership of rangeland societies.

Membership statistics for the world's two largest professional rangeland so- cieties indicate that trend (See Table 1.) Both the Society for Range Management (SRM) of North America and the Australian Rangeland Society (ARS) experienced a sharp decline in total membership during the 1990s. In the SRM, membership reached a peak of 5,046 in 1992 but declined by $25 \%$ to 3,801 in 2001 . Note that the membership peak preceded the initiation of sweeping changes in public land management policies by the Clinton administration that favored preservation over utilization of these lands. In the ARS, membership declined by $52 \%$ from a high of 638 in 1989 to 420 in 2001.

Of just as much concern as dwindling membership is the internationally narrow representativeness of these societies; only about $2.5 \%$ of the SRM members are not from the USA while about $12 \%$ of the ARS members are from abroad (about $5 \%$ from the USA). Thus the interests of people inhabiting many of the worlds rangelands are not being effectively represented by any professional rangelandfocused organization. An exception occurs in South America, where the Asociacion Argentina de Manejo de

Table 1. Membership statistics of the Society for Range Management (SRM), and the Australian Rangeland Society (ARS)

\begin{tabular}{lrrrrrrrrrrrrr}
\hline Year & 1989 & 1990 & 1991 & 1992 & 1993 & 1994 & 1995 & 1996 & 1997 & 1998 & 1999 & 2000 & 2001 \\
\hline SRM & 4471 & 4608 & 4611 & 5046 & 4933 & 4843 & 4510 & 4411 & 4056 & 3827 & 3628 & 3846 & 3801 \\
ARS & 638 & 630 & 506 & 567 & 487 & 487 & 520 & 482 & 459 & 405 & 553 & 420 & 420 \\
\hline
\end{tabular}


Pastizales Naturales, consisting of nearly 300 members, was formed in May 1999 in response to the increasing need of rangeland-based livestock producers for a representative body.

\section{Addressing The Challenge}

To focus the global debate about the future of the rangeland profession and to prevent it from becoming increasingly marginalized in the natural resource management arena, the International Affairs Committee of SRM sponsored a symposium on the future role of rangeland professionals in the face of social change. This symposium was held on February 20, 2001 at the $54^{\text {th }}$ annual meeting of the SRM in Kona, Hawaii. The following articles are from that symposium. They offer a historical perspective of rangeland management and address the challenges that face future rangeland professionals in several rangeland-dominated countries. Most importantly, these articles identify several key skills future range professionals will need to adopt in order to serve rangelands and all the consumers of this diverse resource effectively.

Editors are assistant professor, Department of Rangeland Ecology and Management, Texas A\&M University, College Station, Tx., 77843-2126, USA; and biologist Semiarid Prairie Agricultural Research Center, Agriculture \& Agri-Food Canada, P.O. Box 1030, Swift Current, SK S9H $3 X 2$, Canada

\section{References}

Dobrowolski, J.P., 1992. The future of range education. Rangelands, 14(3):133-144.

Hart, C.R., and D. Rollins, 1999. Who knows the SRM in Texas? Who cares? Rangelands, 21(3):19-21.

McClaran, M.P. 2000. History of the range curriculum: Are there new trails? Rangelands, 22(6): 23-27.

Trlica, M.J., D.L. Drawe, J.A. Young, and P.F. McCawley, 2000. Attitudes about range research. Rangelands, 22(5):13-14.

\section{What's Been Said Before}

Future directions for rangeland research in North America have been discussed in the past. In 1997, SRM's Research Affairs Committee conducted a survey of SRM members (Trlica et al. 2000). Survey respondents indicated:

1) The most important short-term research issues were to develop new, practical ways for measuring range vegetation and initiate systems approaches to rangeland management and livestock production.

2) Important long-term (10-year) research issues included addressing ecological and economic sustainability, problems of increasing urbanization, and the need for social awareness.

In addition, survey respondents identified a broad array of environmental problems requiring study including biological diversity, ecological sustainability, and restoration ecology. Many considered land-use conflicts, wildlife, recreation, and urbanization as issues of growing importance. They also indicated a continuing need for research in core rangeland subjects including succession, rangeland health measurements, and grazing management.

Another workshop and a symposium held in 1991 and 1992 identified several critical areas needing attention for the effective education of rangeland professionals. (Dobrowolski 1992). Strategies for improvement included:

1) Providing students with training in basic skills and critically thinking rather than an abundance of highly specialized coursework;

2) Exposing graduate students to global-scale and socio-economic/human ecology issues while placing greater emphasis on ecosystem-level management, environmental issues, and alternative rangeland uses;

3) Providing continuing education opportunities for rangeland professionals in order to keep them informed about changing technologies, land uses, and values pertaining to rangeland resources; and

4) Expanding extension efforts into audiences beyond producers, rural homemakers and agricultural youth.

A review of rangeland curricula concluded that in North America curricula have grown in breadth, have become more standardized, and have set educational standards for federal employees, but that they need to address additional needs in order to remain current (McClaran 2000). In particular:

1) Curricula should be coordinated with non-traditional rangeland management employers to convince them that rangeland graduates are well trained resource managers;

2) Rigorous continuing education curricula should be developed and integrated into university structure;

3) Newly developed interdisciplinary natural resource curricula should not abandon the range discipline subject matter.

In addition to the preceding initiatives, joint meetings of related societies have been contemplated or attempted in part to address the dwindling attendance at conferences due to declining membership. The Society for Range Management and the American Forage and Grassland Council held a joint national conference in February 1999 to identify potential synergies between the two groups. At the international level, a proposal for a joint meeting of the International Rangeland Congress (IRC) and the International Grassland Congress (IGC) was discussed (but voted against) at the $1999 \mathrm{VI}^{\text {th }}$ International Rangeland Congress in Australia.

To increase the visibility of rangeland research worldwide and in response to declining contributions to national rangeland-related journals, the formation of an international rangelands journal is also being considered in the Australia, South Africa and the USA. 


\title{
Second In A Series
}

\section{Preparing For The Future Of Range Science}

\section{Future rangeland professionals will continue to need strong tech- nical knowledge, but more importantly they will need strong criti- cal-thinking, communication and political skills.}

\author{
By Urs Kreuter
}

Author's Note: The "Rangeland Professionals and Society: Future Directions" Symposium at the 2001 Annual SRM Meeting identified several strengths and weakness of the range manage ment profession. Following is an overview of the future issues identified by the symposium that will shape our profession. Specific topics will be addressed in following issues of Rangelands.

Differing opinions have haunted our profession from the beginning, and compromises necessary to satisfy the broad membership of our professional societies has resulted in unclear and sometimes conflicting policies. However, our ambiguous identity represents both strength and weaknesses.

A strength is that it reflects the diverse, sometimes contradictory interests of people involved with rangelands. For example, rangeland societies include both scientists (theorists) and practitioners (managers). A contrasting weakness of ambiguity is that it is difficult to define and market broad "fuzzy" concepts in simple terms.

Two additional problems are weak professionalism and poor understanding for the basis of knowledge. Both have contributed to a lack of recognition of the range science discipline among policy makers, and have contributed to a poor public image about our profession and its role.

In trying to determine the future role of rangeland "professionals" in natural resource management, both the strengths and weaknesses of our pro- fessional identity must be clearly addressed. Only then can our profession obtain the necessary visibility and credibility to maintain integrity and meaningful contributions to societies in the future.

\section{Range Science Is Changing}

In order for the range profession to retain widespread relevance, it is necessary to include not only academics, researchers and extension personnel in the group, but also landowners, local community leaders and practitioners.

It is often assumed in the developed world that university degrees are a prerequisite for professionalism. However, acronyms for "professional" include skilled, experienced, proficient, expert, learned, trained, able, adept and masterful. Clearly, the attainment of some of these attributes is not restricted to formalized higher education; indeed some might be obtainable only through direct individual experience.

Moreover, given that the bulk of the world's population lives in less developed countries where dispersed societies have often accumulated longterm indigenous knowledge of local conditions, the concept of "professional" needs to be broadened to incorporate people with local knowledge in order to be socially meaningful and locally applicable.

When societal goals for rangeland were commodity production and soil conservation our profession responded well, but it has been poor at keeping pace with changing social demand (see "Range Management's Record" by Thad Box on the following pages). For example, while we have gained much knowledge about soil, plant and animal processes at the scale of research plots and range sites, we have generally been slow to apply this knowledge at watershed, ecosystem, or regional environmental planning scales.

Rangelands are becoming more valuable in developed countries as societies become increasingly urbanized. More people want open space, clean water, wildlife habitat, a rural lifestyle, and livestock-free goods and services that are unique to rangelands. (This will be discussed by Mitch McClaran in an article in the December 2001 issue.)

In countries such as Canada and Australia, where the majority of the population is restricted to and growing most rapidly in a few urban centers, regulatory changes that impact rural land use can seriously affect the economic and cultural attributes of rural communities. This is becoming especially apparent in rangeland-dominated drainage basins that are the primary water source for rapidly growing population centers, particularly where water supply is declining.

In such cases, the rapid growth in demand for high quality water will 
likely become the primary criterion driving regulation of rangeland use because reconciling regional water budgets will present an ever-greater challenge for public policy ("Water's Role" will also be discussed in further detail in the December 2001 issue). In addition, the reduced influence of rangeland production in world and national affairs, together with the growing influence of energy politics and technology and trade treaties is likely to further accelerate the regulation and conversion of rangeland use for nonlivestock-related priorities.

Developing countries also face additional socio-political dynamics that affect their rangelands. In Africa redress legislation aimed at "Africanizing" government institutions and research policies that emphasize resource-poor rural economies have led to a depletion of an already small number of rangeland scientists. Rural policies in China typically focus on agricultural production instead of ecological sustainability and, therefore, are placing increasing pressure on rangelands that contain the headwaters for many of Asia's major rivers.

The low or declining level of trained natural resource expertise in most developing countries make it imperative that local communities are centrally involved in finding solutions to problems affecting the natural resources upon which they depend. Greater participation of local communities in resource management is increasingly being incorporated in international efforts to elevate resource-poor rural economies in developing countries. Such initiatives will require greater involvement by trans-disciplinary teams - including multi-facetted natural resource experts.

In the future, potential clients for rangeland professionals will increasingly expand beyond ranchers and land management agencies. In the USA and Canada they will include more small-tract landowners, land trusts and conservancies, homeowners associations, non-traditional resource management agencies, county plan- ning departments, weed abatement and water districts, and highway departments. In developing countries, such as South Africa, attempts by the mining and other industries to meet internationally recognized environmental auditing practices will also provide new opportunities for input by rangeland professionals.

The rangeland profession will also increasingly draw a more diversified group of students. As societies continue to become urbanized, future natural resource management students are likely to include an ever-greater proportion of women, urban-born people, and minorities.

\section{Meeting The Challenge}

As any entry-level marketing course will teach, increasing the value of a resource necessitates a clear understanding of the evolving societal demand for that resource. To expand the value of the services that it can provide, the rangeland profession needs to expand its horizons to encompass the full spectrum of rangeland uses, including but not limited to traditional uses.

To circumvent alienation, the rangeland profession must also avoid defensive reaction to inquiry and criticism about its role, and it must be sincerely and openly receptive to differing points of view and values.

It is critical to elevate the profession's visibility and perceived relevance by increasing the awareness of policy makers, agencies and the public at large about the diverse services that rangeland professionals can offer. Addressing rangeland-related issues in a regional context that promotes strong partnerships between key regional stakeholders and improves environmental, economic and social outcomes of rangeland policies will also elevate awareness.

Although future rangeland professionals will continue to need strong technical knowledge, more importantly they will need strong critical-thinking, communication and political skills. Previously developed skills and knowledge can be applied to livestock-free situations, ranchette planning that minimizes rangeland fragmentation, endangered species habitat management, and rangeland tourism.

Greater training in collaboration and mediation skills will greatly facilitate their involvement and leadership in environmental impact analyses, the establishment of conservation easements, and coordinated resource management plans in areas with diverse groups of stakeholders. Such involvement will require knowledge about ecology, economics, and geographic information system (GIS), as well as social and leadership skills that facilitate public debate.

Instilling cultural sensitivity in rangeland professionals is also increasingly important as Western influence on developing countries grows. Such sensitivity will enable rangeland professionals to merge the best aspects of traditional rangeland management systems with new technologies and development paradigms by fostering partnerships with local communities.

Such broad expertise requires a more holistic, multidisciplinary approach to training, research and extension that integrates ecological, technological, socio-economic, business, cultural, and institutional issues. The increasingly multi-facetted nature of the profession will necessitate continuous training of rangeland professionals in evolving technologies (e.g., global position system (GPS) and GIS applications). Because of the rapidly changing scope and power of such technologies, regular attendance by rangeland professionals of well-planned workshops must also be encouraged. In addition, in developing countries, the widespread perception that the rangelands are of little value because of their association with rural poverty must be squarely addressed by enabling and encouraging young native people to pursue meaningful careers within the profession.

Larger rangeland society membership with broader academic and pro- 
fessional experience is vital for the profession to develop and share the knowledge and skills necessary for responding to changing societal values for natural resources. Professional rangeland societies have a central responsibility in this regard. They must aggressively maintain the interests of existing clients, and they must attract new clients by effectively marketing the virtues of the expanding breadth of skills and knowledge represented by the profession.

Such initiatives require not only concerted effort but also financial resources and the services of professional marketing specialists. If the professional societies do not take this challenge seriously, frustrated or disen-franchised members will increasingly migrate to other natural resource societies that explicitly recognize the value of diversity or will move into other areas of endeavor.

A common theme of rangelands is their great diversity. The strengths of the rangeland profession are the diverse interests and expertise of its widely dispersed members. Failure by professional rangeland societies to fully recognize and exploit this diversity and to effectively market the value that it represents for the sustainable manage-ment of natural resources around the world will lead to a slow death for these societies.
As a profession we must be able to unequivocally answer the question about our profession's identity by stating that we represent the full spectrum of knowledge and skills regarding the nature and uses of the world's most widely distributed and diverse land type-rangelands.

Author is assistant professor Department of Rangeland Ecology and Management, Texas A\&M University, College Station .

Editor's Note: This article was presented at The "Rangeland Professionals and Society: Future Directions" Symposium at the 2001 Annual SRM Meeting. 


\title{
Third In A Series
}

\section{Range Management's Record}

\section{A review of why range management came about, what it has ac- complished and what society will need from range professionals in the future.}

\author{
By Thad Box
}

Our record says we speak for the land. Our critics say we only support the ranching industry and that we are willing to drastically change natural systems for unworthy ends. They charge that range management has emphasized products and production, improvement over nature, and technology. They are partially correct. We provide products and services society demands. We use technology. We manipulate proudly. But they are wrong that our manipulation hides dark objectives that go against what society wants. We try to get what people need without harming land.

Range management began in response to a decline in land productivity caused by livestock grazing. It evolved as society made new demands on the land. We now have an identity crisis because we have not adjusted to what people now want. We are stuck in the past.

When Europeans first came to the USA, they brought with them a new culture, new technology, and new biological organisms. To argue the "right and wrong" of their actions is futile. It has been done. They came and they changed the land forever. Range scientists and livestock opponents have told this story of the rise of livestock industry and the decline of rangelands. Each tells the same, sad story, with a slightly different spin.

Exploitation once fit our national policy. Natural resources, whether forests, rangeland, or water resources were there for the taking. A new country needed money and people. In their zeal to conquer the wilderness and produce income for an emerging country, they abused the land. Society wanted products to enhance the lives of people. They overused their resources. Scientists began by documenting land abuse in the late $19^{\text {th }}$ century. Botanists and agriculturalists assessed the results of past damage and suggested ways to correct them. The beginning of range management started as scientists responded to public concern about rangeland deterioration. and mud slides came from the mountains, covering towns and villages. Forest reserves were set aside. Public lands were used as a commons. Indian land use was steered toward white culture objectives. Dust from rangeland blew to Washington.

There was a need for tools to evaluate land potential and regulate its use. The scientific response was descriptive and practical. Guidelines for calculating carrying capacity for livestock were developed. Ways of documenting erosion, plant cover, and soil stability were determined. Scientific

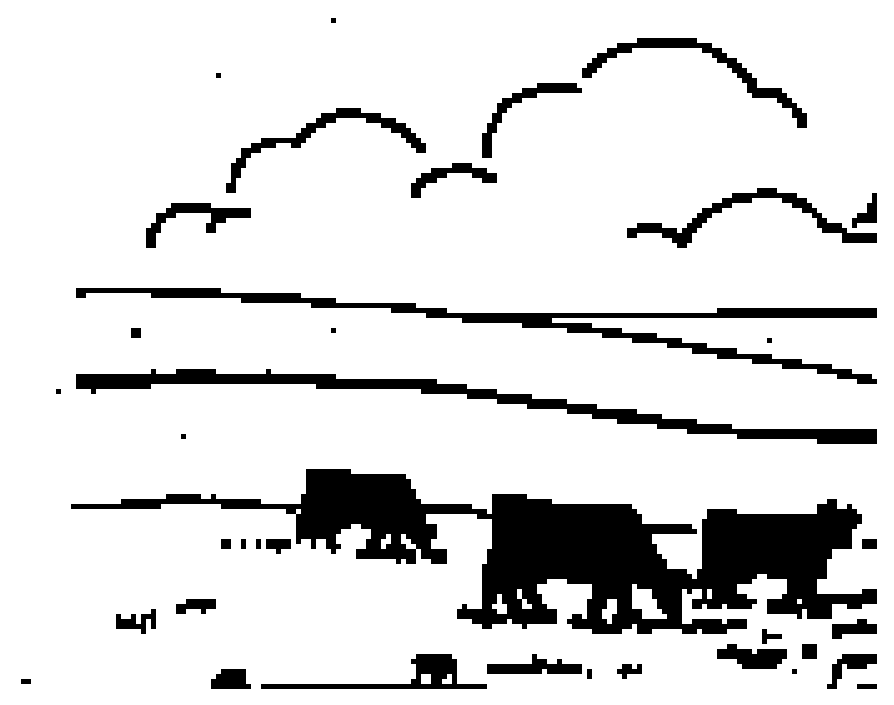

Range management developed to balance land uses with land capability. Use was excessive, ranges were overgrazed, and forests were cut. Floods range management began to move from descriptive to functional with the development of the concept of ecological succession. For the first time, 
managers had a scientific theory with which to assess and predict rangeland response. The teachings of Frederic Clements, and his publications on plant succession had a strong and continuing effect on our profession. Although we have moved from the Clementsian paradigm in favor of more modern ecological theory, many of our practices are still rooted in a theory we now think faulty.

The publication of Jardine and Anderson's bulletin in 1919 on the management of livestock on national forests and Sampson's paper on plant succession and grazing the same year brought together the practice and theory behind the fledgling profession of range management. Textbooks began to solidify the concepts and practices.

Research on rangelands began when the first range experiment stations were established in Texas in response to overgrazing in the 1890 s. In the decades following, each new experiment station and each new research agency was established and funded because the taxpayers wanted ways to supply their wants. These ranged from safety from mudslides to more meat and wool. Gradually, a body of knowledge for the management of rangeland developed.

The first range management college courses were taught in the early 1900s. Several universities-among them Idaho, Montana, Utah State, and California-claim to have taught the first range courses. Because early courses were taught in unlikely departments, often with titles that were not descriptive, there are disputes over when the first range course was taught, where it was taught, and who taught it. Courses and curricula were developed in response to several different societal demands. Courses in forage or economics spoke to specific problems in agricultural production. Others addressed conservation needs such as soil conservation or watershed management.

Senate Document 199 "The Western Range" (1936) was the first major paper summarizing the status and con- dition of the American range. It was a political document issued by the Forest Service, written by Forest Service employees, in an attempt to move the public lands into the Department of Agriculture. Despite its political intent, it represents the first professional opinion by range managers about American rangelands.

Like the academic programs that produced them, range managers found themselves answering to different professional groups. Foresters, agronomists, biologists, and livestock producers all had organizations with range folks in them. No professional society spoke solely to the needs of rangelands. In 1946 Vernon Young chaired an Interagency Range Management Conference at the University of Idaho. A committee was formed to explore a separate society for range "men." The American Society of Range Management held its organizational meeting in Salt Lake City in January 1948. Its original officers consisted of four government agency employees, three academics, and one rancher.

The pioneers that formed our profession were generalists. Each was typically trained in ecology, forestry, agronomy, or animal husbandry. They were united by a common goal-improve the management of rangeland. In order to address rangeland management more effectively, new disciplines such as economics, sociology, and other social sciences were welcomed into the society.

\section{Conflicting Views Shaped Our Profession}

A number of dichotomies have haunted our profession from the beginning. Compromises necessary to satisfy the broad, diverse membership ended up with unclear and often conflicting policies.

Conflicting views about range as a use or range as a kind of land has confused us from the start. The objectives of our society, printed in the front of every journal, speak of rangeland re- sources, range resources, range ecosystems, range environment, soils, plants, and water. It does not mention a use. Most members agreed range was a kind of land, but some government agencies considered range a use. Their pamphlets and public relations material listed timber, wildlife, water, recreation, and range as land products. Many critics of range management think we still see range as a use.

The difference in objectives for using private and public land is another dichotomy. Private lands are usually managed for individual gain, the gain of a family, or the profit of corporate shareholders. The very fact they are privately owned suggests a return on investment. Public lands, on the other hand, are managed for the public good. Societal goals for these lands are spread over a large diversity of people with different wants and desires. No single use can be maximized. The mix is optimized to satisfy many. We claim to speak for the land regardless of ownership or use.

The poor and the wealthy want different things from rangeland. The poor want food, shelter, safety, and a chance to improve their standard of living. The rich already have these. Poor people want immediate improvement of their lot. This often means products. The rich may desire "ecological services," viewed as intangibles by the poor. Society wants ranges to be used both for immediate economic gain and potential future uses. We want to keep options for future uses open.

We disagree whether we are analysts or advocates. Some say we should only do good science. Leave policy to politicians. Others say we must advocate for sustainable landscapes. The dichotomies of our profession will remain with us. We cannot settle them here today, but we must deal with them.

\section{Emerging Societal Needs}

The nation's wants have changed. Beef and wool are no longer the most valued products. People want food 
safety, "healthy" food, bottled water, and "ecological services." We struggle to adjust to that change. Our profession evolved to meet demands society made on rangelands. In our self-analysis of who we are, we must face up to what people now want.

In poor countries ranges are depleted and overused. Wants of the people center around survival. Food, water, fuel, human health, and education have higher priorities than aesthetics or maintaining endangered plants and animals. These poor cultures have responded by trying to modernize, industrialize, and externalize the effects of their industries. Range manager's role in such countries is the production of goods and services, much the same as American range managers did in the early $20^{\text {th }}$ century.

By contrast, rich countries want luxury consumption of everything from food to fuels. They want to move the impact of their luxurious lifestyle to poor countries. Wants of the people in rich countries include clean water and air, freedom from pollutants, ethical treatment of animals and plants, aesthetics, open space, beauty and an "organic" diet produced elsewhere.

\section{Four Options For The Future}

Our response to societal need was adequate, and in many cases excellent, as long as goals were production of commodities or soil conservation. Our current range profession is compatible with the aspirations of poor countries. It can continue to thrive on private land in rich countries. However, most range managers live in rich countries where society does not want traditional products from rangeland. SRM evolved and organized to meet needs society wanted a hundred years ago.

We do not understand what society now wants. We make feeble attempts at choosing a sexier name we hope will make us more lovable. We refuse to believe that society in our rich countries today wants different things from the land than we are trained to provide. We can pursue several options as a profession.

First, we can resist change. We can continue to address the needs of poor countries and private landowners. We will prosper and be respected in the short run in the places where poverty rules peoples' lives. Ultimately we will go the way of production agriculture, content to be the servant of commodity groups.

A second option is to try to understand what rich societies want from rangelands and develop theory and practice to meet those needs. We have not been very good at listening, much less understanding. For instance, I have heard no serious discussion about how we would organize, what sciences we would use, or what would be our professional objectives if livestock grazing were removed from public rangelands.

By default, we may fall into a third option. We try to change society to fit our world. We "educate" the misguided that grazing is not causing irreparable harm; indeed grazing is good. Even if we are right, we are naive. We ignore the fact that we have evolved as a profession by responding to societal wants. We have no track record showing our profession has credible skills in creating wants.

The fourth option is to focus our attention on science for future conditions and needs. Let others fight political battles of competing uses. We can develop basic science that can be applied to land health whether it is a cattle ranch or a biodiversity reserve devoid of domestic animals. We remove ourselves from the trauma of conflicting uses. We become the ivory tower scientist.

Or we keep flailing around and die a slow death. Or fold our tent and slowly walk away.

But we must not die or walk away. Our cause is just. Our mission is as valid as it ever was. Only the environment in which we seek it has changed.

Author is a long-time member and past president of the Society for Range Management.

In the next issue of Rangelands, this series will look at "Future Rangeland Uses" and "Water's Role." 


\title{
Grass-Fed: Nature's Intention
}

\section{According to recent studies, grass-fed animals produce leaner, healthier beef.}

\author{
By Dawn Rahn
}

Think back to several centuries ago when Native Americans lived in harmony with nature. Fast forward to the $21^{\text {st }}$ century where there is a trend in America to go back to nature. Many farmers and ranchers are returning animals to the open pasture, and in return are eating healthier meat products and employing natural range management practices.

Traditional producers have a meat product that is higher in more of the bad fat that clogs our arteries and less of the good fat essential for better health. Often times the dietitians for people with a diet high in saturated fats say eat less red meat. But new research suggests eating less grain-fed meat and eating grass-fed meat, which is leaner, actually lowers cholesterol levels.

Along with leaner meat, grass-fed animals have a higher amount of a type of good fat called "Omega-3 fatty acids." Omega-3 fatty acids are not only good for your health but they are essential for normal growth and development. Grass-fed meat has from two to six times more Omega-3s than grain-fed meat.

Omega-3 fatty acids are not only beneficial to your health, but they also help in normal growth and development. These acids cannot be manufactured in your body, so they must be received from your diet. Omega-3 fatty acids contain many disease-fighting contents. The brain is largely made up of fats, and Omega-3 fatty acids make up the most important part of those fats.

If you receive a proper amount of these fatty acids in your diet, it has been found that the risk of having mental disorders, aggressive behavior, or attention-deficit disorder can be lowered. People with diets high in Omega-3s are also less likely to have high blood pressure, heart attacks, or cancer.

Unfortunately, the American diet is sufficiently low on Omega-3s. Only $40 \%$ of Americans consume adequate levels, and $20 \%$ have levels so low they can barely be detected. The reason for the decline in Omega-3s in grain-fed animals is that Omega-3s are formed in the green leaves of plants. When animals are taken off grass and fed grain, they gradually lose their storage of these fatty acids. For this reason, grass-fed animals are in high demand from the consumer.

\section{Bison Also Good Source Of Omega-3s}

Bison, an animal group once considered on the brink of extinction, is one group of animals that appear to be at home on the range. They are making an increase in population due to consumer demand for their meat. By the late 1800 's, bison were nearly extinct. Through the help of conservationists and ranchers who know the value of bison, they have begun to increase in number.

The Perfect 10 Ranch located south of Rose, Nebraska raises grass-fed bison. The ranch currently has 50 pasture subdivisions. The meadows are used heavily in the summer, and the warm-season Sandhills native grass is usually saved and used for winter

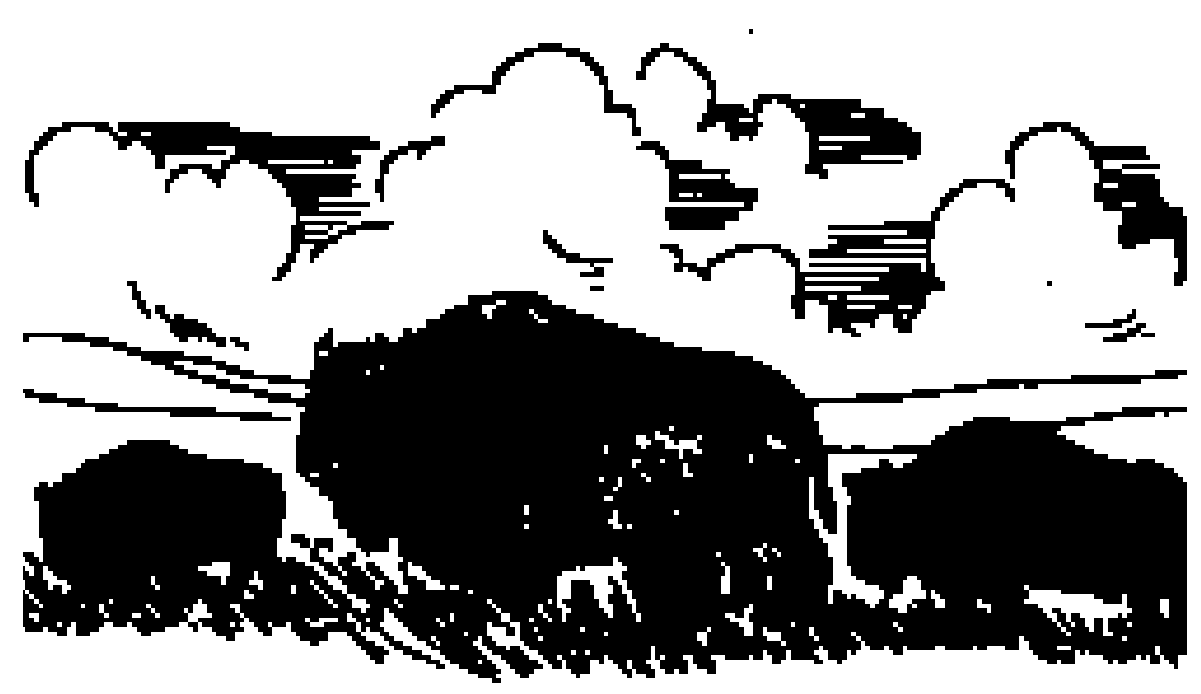


grazing. With this grazing program, the owner of the ranch has found that his warm season grasses have grown back in larger amounts with the plants having stronger root systems. Among these are grasses such as Big Bluestem, Indiangrass, and Switchgrass. The operator likes to use a herd size of around 900 animals, which are moved about every three days during the grassgrowing season.

Bison are higher in protein than beef, but lower in fat, cholesterol, and calories. However, many of these animals are being taken off grass and put on feedlots where they are losing their essential Omega-3 fatty acids. Bison are very efficient grazers, so feeding them grain makes little sense. The grazing bison will lose weight during the winter months, but when spring comes, they can rebound quickly and regain their weight. They are not such efficient grain consumers, so all grain does is make their amount of bad fats higher, and lower the overall meat quality. In some cases, grain-fed animals also have higher amounts of Ecoli, which can be dangerous to the consumer's health.

Another reason grass-fed bison are healthier for the land and consumer is the fact that they are survivors. It has been found that fewer bison die during extreme cold or hot weather than other grain-fed animals because of their naturalness. Bison are also the only mammal that has never had cancer. They are roamers and move about every three days.

With their movement, they help improve the land by churning the soil with their sharp, split hooves. This allows new plant growth and a healthier root system. If a pasture has a healthier root system, it is better able to contain water. The bison work their own urine and manure back into the soil, fertilizing and speeding the decomposition process naturally in about ten days. These animals also break up frozen soil in the spring, allowing water to percolate into the soil. When they shed their shaggy winter coats by rolling on the ground, autumn seeds

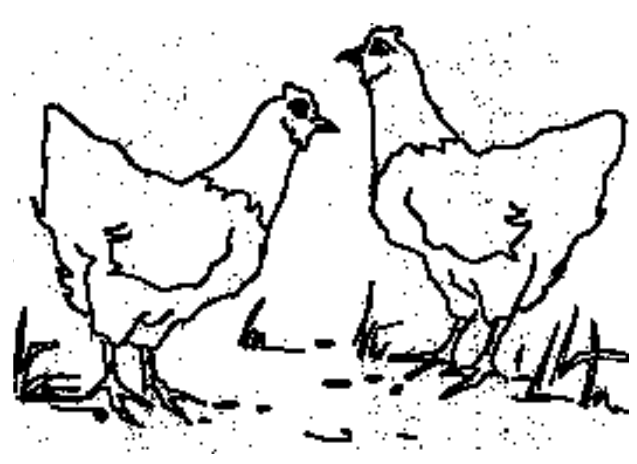

Omega-3s. In addition to being healthier grass-fed poultry is appealing to the taste buds.

Grass-fed animals appear to have advantages over grain-fed animals. The main advantages include the health benefits of the Omega-3s, and range management practices that allow better plant growth and efficient use of range land. Although grassfeeding animals, is only one alternative to a healthier animal product, many people are recognizing grassfarmers as excellent caretakers of our environment.

caught in their hair are redeposited, resulting in native grasses growing anew. Bison also eat dead grass, thus reducing fire hazards and allowing easier photosynthesis for new grass. Uneven land is leveled by bison, since they break down bumps and kick up clots in pasture ruts.

\section{Poultry Can Be Grass-Fed}

Along with grass-fed bison and cattle, poultry can also be grass-fed. However, unlike ruminant animals, poultry cannot survive on grass alone. They need forms of high quality protein, such as insects, grains, or legumes. Chickens that are raised on pasture will get as much as $30 \%$ of their calories from grass, clover and other greens.

Poultry traditionally are vaccinated, medicated, and exposed to artificial lighting. A recent study showed that after vaccination or medication is out of a chicken's blood, it could show up in the eggs. With grass-fed management practices chickens do not have this problem, because they are not vaccinated or medicated.

Another issue again is the Omega$3 \mathrm{~s}$. Unless given the chance to eat greens where Omega-3s are most abundantly found, the eggs laid by these animals had a 20-1 ratio of 20 eggs with sufficient Omega- 3 s to 1 eggs with sufficient Omega-3s. In other studies it has been discovered that grass- fed chicken meat is healthier than conventionally raised chickens. The free-range chickens were lower in fat and calorie percentages, yet were higher in vitamin $\mathrm{A}$ and
This was the second place paper for the High School Youth Forum presentation competition at the SRM Annual meeting in 2001 in Kona, Hawaii.

Dawn Rahn can be contacted at HC 68 Box 7, Atkinson, Nebraska 68713, Phone: 402-925-2609.

\section{References}

Nation, Allen, "Large and Small Herd Buffalo Ranchers Find Grassfed Meat to be a Lucrative Enterprise", The Stockman Grass Farmer July, 1999. Vol.56, \#7

Robinson, Jo, Why Grass fed is Best. Vashon, Washington,: Vashon Island Press, 2000.

Schulte, Erin, "Survival of the Fittest: A Beastly Will to Survive", Back From Oblivion, Depth Report 28, October, 1997, College of Journalism and Mass Communications, University of Nebraska at Lincoln.

Interview with Dave Hutchinson, Perfect "10" Buffalo Ranch, HC 75, Box 146, Rose, Nebraska, August 8, 2000.

Interview with Chuck and Bev Henkel, Tucker Hill Farm. 1614 N. 61 ${ }^{\text {st }}$, Norfolk. Nebraska, August 6, 2000. 


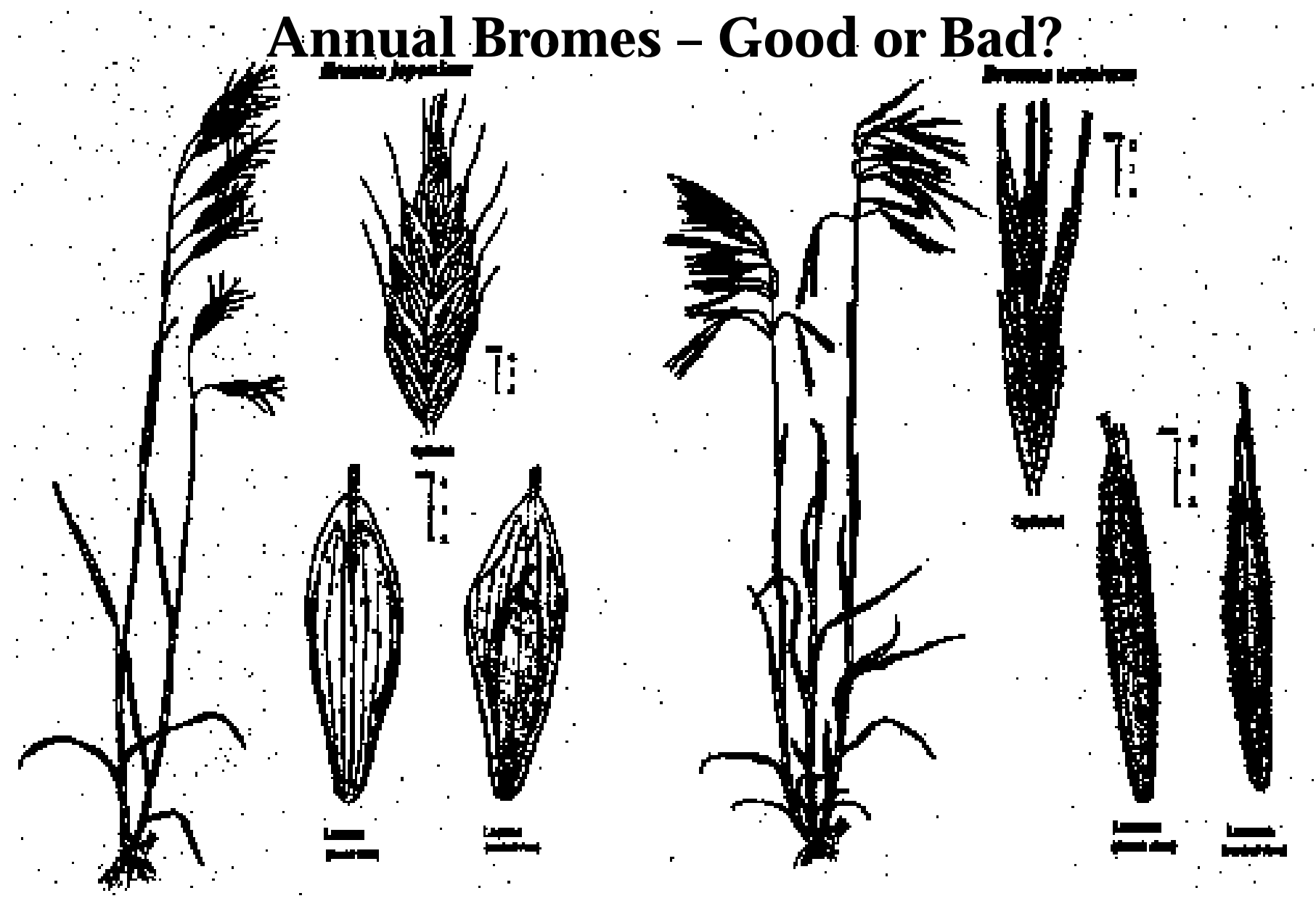

\section{A question and answer on the impact annual bromes have on rangelands.}

\section{By Marshall R. Haferkamp}

Are annual bromes good or bad? Japanese brome (Bromus japonicus Thunb) and downy brome (B. tecto rum L.) -weedy cool-season annual grasses - have invaded thousands of acres of the Northern Great Plains, Great Basin, California Annual Grasslands, and Palouse Prairie. What is the impact of annual bromes on infested range lands? During my range research career, I've had several personal experiences with annual bromes.

Colorado and South Dakota: My first encounter with annual bromes was in the mid 1960s while attending Colorado State University in Fort Collins. At that time I did not realize that working with annual bromes would become such a large part of my future research career. As a student, I saw downy brome on a daily basis during laboratory assignments and on part-time jobs. I encountered Japanese brome in South Dakota while working with professor Tex Lewis. By 1968, Japanese brome covered relatively large areas in the exclosures and lightly grazed pastures at the Cottonwood Experimental range in western South Dakota.

Oregon: I began research work with annual bromes in 1981 when I moved to Burns, Oregon. Downy brome was one of the major species we had to control before establishing successful range seedings in the Northern Great
Basin and Palouse Prairie. Annual bromes have invaded vast acreages in the Great Basin and Palouse Prairie. These acreages are maintained in part by the cyclic fire regime of the regions. Establishing autumn seedings of cool-season grasses was enhanced by reducing competition from annual bromes. We generally were successful when we prepared seedbeds by a combination of (1) reducing brome seed yields with fire in the spring or early summer and (2) reducing density of emerging brome seedlings after autumn rains with herbicides or tillage.

Montana: I moved to Miles City during a drought in 1988 and saw few annual bromes in this area of the 
Table 1. Ungrazed spring forage yield sampled in May and June at Fort Keogh.

\begin{tabular}{|c|c|c|c|c|c|c|}
\hline \multirow[b]{4}{*}{ Year } & \multicolumn{6}{|c|}{ Species groups } \\
\hline & \multicolumn{3}{|c|}{$\begin{array}{r}\text { Grasses } \\
\end{array}$} & \multirow[b]{3}{*}{ Sedges } & \multirow[b]{3}{*}{ Forbs } & \multirow[b]{3}{*}{ Total } \\
\hline & W. wheatgrass & & & & & \\
\hline & S. bluegrass & Annual & Other & & & \\
\hline & 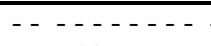 & 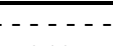 & - -(poun & $\overline{\mathrm{re})---}$ & $\overline{----}$ & $-\cdots$ \\
\hline 1983 & 239 & 343 & 210 & 25 & 104 & 922 \\
\hline 1984 & 170 & 301 & 60 & 16 & 27 & 573 \\
\hline 1985 & 196 & 170 & 52 & 11 & 52 & 480 \\
\hline 1986 & 581 & 183 & 74 & 21 & 89 & 950 \\
\hline 1987 & 434 & 236 & 59 & 18 & 69 & 816 \\
\hline 1988 & 246 & 23 & 53 & 6 & 36 & 364 \\
\hline 1989 & 382 & 373 & 51 & 11 & 57 & 822 \\
\hline 1990 & 468 & 452 & 60 & 27 & 51 & 1,057 \\
\hline 1991 & 310 & 632 & 33 & 0 & 19 & 994 \\
\hline 1992 & 267 & 242 & 32 & 0 & 20 & 560 \\
\hline 1993 & 302 & 126 & 79 & 24 & 75 & 608 \\
\hline 1994 & 522 & 28 & 97 & 4 & 46 & 695 \\
\hline 1995 & 433 & 117 & 79 & 29 & 82 & 740 \\
\hline
\end{tabular}

${ }^{1}$ Western wheatgrass and Sandberg bluegrass.

Northern Great Plains until 1989, a year with above average annual precipitation. It became apparent, after looking at published research in the late 1980s, that annual bromes did not have much impact in the region before the mid 1950s. However, data collected in the 1980s clearly indicated that annual bromes could provide a large proportion of the spring forage produced in the Northern Great Plains. As with most annual grasses, herbage production from annual bromes is erratic from year to year (Table 1). Early maturation of annual brome plants impacts rangelands in two main ways. Brown mature herbage is poor quality for grazing livestock and provides fine fuel for fires.

The literature I reviewed, exposed many gaps in information on annual bromes in the Northern Great Plains. Particularly missing was information on the impact of annual bromes on production of native vegetation and livestock. We also did not know if annual brome seeds produced in the Northern Great Plains germinated and responded to environmental factors similarly to bromes growing in other regions of the United States. From a series of studies on annual bromes conducted in the Northern Great Plains at the Fort Keogh Livestock and Range Research Laboratory near
Miles City, Montana, here is what we've found:

\section{How does environment affect} establishment and growth of annual bromes?

Abundance of brome depends on availability of seed, amount and distribution of rainfall, temperature, and availability of soil nitrogen. Brome is most abundant in years following wet autumns and most productive in years with abundant autumn and spring rainfall. Cool temperatures during the growing season will prolong growth of annual bromes, and adding nitrogen to the soil increases forage production as shown in some fertilizer studies in the region.

All of the environmental factors work together to impact annual brome production. While it is relatively easy to determine whether density of annual brome plants will be great in a given year, it is difficult to know how much and how long forage will be produced by the bromes.

\section{What conditions promote seed} germination and seedling establishment?

More than 10,000 annual brome seeds can be present in a square yard in the mixed-grass prairie of the
Northern Great Plains. Seeds will generally germinate over a wide range of temperatures that often occur in late summer and autumn, but soils usually need to be moist for 3 to 5 days for seeds to germinate. Litter enhances germination and seedling emergence by conserving soil water. Seeds can germinate in spring, particularly after dry autumn and winter periods, when soil water is available during spring.

The high level of germination exhibited by Japanese brome in our studies suggests a large portion of the ripe seeds will germinate with available water during late summer and early autumn. However, a percentage of the seeds that do not germinate by lateSeptember can become dormant when water is taken up at or below $32^{\circ} \mathrm{F}$. This dormant state can last through the next winter, spring, and summer. This characteristic aids annual brome's persistence on rangelands, because seedlings emerging in August and September in any year likely come from two seed crops, the current and previous years. Emerged seedlings will over-winter and begin growth in early spring.

Harvesting stands of Japanese brome for hay may reduce the seed bank in one area and increase the seed bank where the hay is fed. We found that Japanese brome seed could germinate when harvested green in midJune. It is best to feed Japanese brome hay only on brome infested areas.

\section{Do annual bromes compete with established native perenni- al grasses?}

Annual bromes add to the total forage base at the expense of perennial grasses. When we removed annual bromes from mixed-grass prairie communities, total yields were reduced an average of $23 \%$ and western wheatgrass yields increased $23 \%$. The shortterm increase in production of western wheatgrass was due to an increase in number of shoots, rather than an increase in weight of individual shoots. The ability for brome to suppress for- 
age production can be expected over a wide array of environmental conditions with variable late spring and early summer precipitation (i.e., 4 to 15 inches) and variation in total forage production (i.e., 1,100 to 2,100 pounds/acre).

\section{Do annual bromes impact live- stock performance on range- lands?}

Many studies have shown a decline in weight gains of stocker cattle as the grazing season progresses from spring to autumn in the Northern Great Plains. Two questions come to mind. How much of this decline is due to maturation and senescence of perennial grasses? How much of the decline is due to the presence of large amounts of early maturing annual bromes?

When we reduced the amount of annual brome chemically, gains of stocker cattle were increased from 2.02 to 2.29 pounds/head/day and from 15.6 to 18.1 pounds/acre from May to September, 1993-1995. We think a portion of the increase in gain was due to an increase in crude protein of diets. Crude protein in diets was increased from $12.6 \%$ to $14.2 \%$ due to both a shift in botanical composition of diets as well as an increase in crude protein concentration in response to the herbicide. Percentage of annual grasses was reduced in the diets in most years, and replaced by a variety of species (i.e., western wheatgrass, forbs, and blue grama).

\section{Will bromes always affect livestock performance on rangelands?}

The $16 \%$ increase in gains of stocker cattle obtained with reduction of annual bromes can occur on other Northern Great Plains ranges. However, results following brome reduction will vary depending on the magnitude of annual production of bromes and the distribution of bromes within a given pasture. Untreated pastures in our study (19931995) were uniformly infested with annual bromes, however production of annual bromes was relatively small compared to other years (Table 1). Increase in livestock performance may have been greater if a greater brome production was removed, but it might have been smaller if cattle were grazing large pastures with spotty distribution of bromes. When bromes are less abundant or abundant in patches, livestock can more easily select perennial species in their diets.

\section{What will happen on brome in- fested ranges in the future?}

We do not anticipate an ecological shift of northern mixed-grass prairies toward an annual grass dominance. We know that the amount and abundance of annual bromes occurring on Northern Great Plains rangeland is cyclic and depends on the seedbank, temperature, and amount and distribution of precipitation. In addition, western wheatgrass and blue grama, two of the dominant perennial grasses, reproduce vegetatively and have long life spans. These species effectively buffer the impacts of Japanese and downy brome in mixed-grass prairie communities, particularly where grazing management strategies maintain healthyvigorous stands of native mixed-grass prairie vegetation. This is in contrast to the overwhelming successful invasion of downy brome into areas dominated by shrubs and bunch grasses in the Intermountain West.

Author is Rangeland Scientist, USDA-ARS Fort Keogh LARRL, Miles City, Montana

The author expresses appreciation to cooper ators Elaine Grings, Rod Heitschmidt, Michael MacNeil, and Michael Karl; Bryon Bennett, Caralea Leidholt, Cheryl Murphy, Duane Bundy, and several summer aides for field as sistance; Emerenciana G. Hurd for plant sketches; and Mary Ellen French for manu script assistance.

This paper is a contribution from the USDAARS and Montana Agr. Exp. Sta., Miles City, Mont.

The USDA-ARS, Northern Plains Area, is an equal opportunity/affirmative action employer, and all agency services are available without discrimination.

Mention of a trade name or a specific propri etary product does not constitute a guarantee or warranty by the authors or USDA-ARS nor does it imply the approval of these products to the exclusion of others.

Figure on page 32 is an illustrations of Japanese and downy brome plants, spikelets, and florets (Courtesy of Emerenciana $G$. Hurd).

\section{Alternatives For Managing Annual Bromes}

Suppression of brome requires environmental and/or managerial reduction of the annual brome seedbank. Even after two years of suppression by burning, herbicides, or grazing the seedbank may contain enough seed to maintain brome populations or allow an increase in its abundance. Nonetheless, here are some management strategies:

Grazing: The best management practice is to graze brome infested ranges in early spring. This way you are negatively impacting the brome while using available forage. Cattle should be removed while adequate soil water is available for growth of perennial grasses. This practice will allow management of but not eradication of bromes. Reducing seed production by defoliation should be an effective method of interrupting the life cycle of annual bromes. Actually, we found you can reduce above- and below-ground biomass and seed production of Japanese brome plants with frequent-intensive clipping in controlled environments. In the field, the brome population is reduced both through reduction in the amount of seed and the amount of mulch or litter.

(Continued on page 35) 
(Continued from page 34).

The biggest challenge to control brome by grazing or mowing is that a narrow window exists in early spring when defoliation can suppress annual brome growth, seed production, and mulch buildup. This approach would require high density grazing for a short duration or carefully timed mowing, during which time bromes would be closely defoliated and/or seed production prevented. Uniformly defoliating brome plants with grazing or mowing and precisely timing defoliation to reduce selection of perennial grasses and allowing the perennials adequate time to recover from defoliation before the end of the growing season is not easily accomplished on any rangelands.

Unfortunately, terminating grazing or mowing when soil water is available for growth of associated perennial grasses may also prove advantageous for annual bromes. It is unlikely all annual brome plants and shoots will be grazed. Consequently, some annual brome plants will always be present to produce viable seed and replenish the seedbank.

Burning: Findings of other researchers have shown increases in forage yields of perennial grasses after suppression of Japanese brome with burning. Burning kills seedlings, reduces seed, and removes mulch. Generally, greater reduction of annual bromes can be expected from burning when precipitation is below normal following the year of burning. This phenomena is a result of reduction in litter accumulation, which will reduce annual brome recruitment, seed production, and seed banks.

Herbicides: Some chemicals that would be beneficial in controlling brome (i.e., atrazine) are no longer labeled for use on rangelands. Wyoming researchers reported promising annual brome control in the late 1990s with both glyphosate and paraquat which are available. Care must be used in choosing times of application to reduce damage to associated desirable perennial grasses.

Finally, realize that annual bromes will persist on Northern Great Plains ranges. Maintenance of a viable livestock industry will require special management skills because this region is characterized by large and rapid changes in forage production, resulting from periods of above and below average precipitation and the invasion of alien weeds. You will have to decide if annual bromes are a problem on your operation. Can they be controlled, or better yet, can they be economically controlled? It is important to determine the botanical composition of pastures and plan their use based on livestock nutrient requirements and the potential of plant species to provide the required nutrients. This inventory is critical for devising management strategies to maximize efficiency of utilization of Northern Great Plains rangelands. 


\section{Resource Roundup}

\section{Farm Bill Looks Good For Conservation}

The House Agriculture Committee has proposed a Farm Bill which includes many priorities geared toward conservation.

The conservation section of the bill devotes $\$ 16.511$ billion, over 10 years, to soil, water and wildlife programs a 75\% increase in baseline spending. The Environmental Quality Incentives Program (EQIP), was reauthorized through 2011 at a $\$ 1.2$ billion annual program level and 2 million acres is authorized in the Grassland Reserve Program to be enrolled in 10, 15 and 20 year contracts.

The bill also contains a provision to facilitate the expansion of high-speed Internet access to rural areas, an important tool for many small businesses, including livestock producers.

\section{Stewardship Winners Recognized}

Regional winners of the National Cattlemen's Beef Association's (NCBA) Eleventh Annual Environmental Stewardship Awards program were recently announced.

Livestock operations from around the country that earned stewardship honors include:

- Region I: Church's Grove Farm, Frankfort, Kentucky

- Region II: Barthle Bothers Ranch, San Antonio, Florida

- Region III: Iowa River Ranch, Union, Iowa

- Region IV: Holcombe Farms, Jay, Oklahoma

- Region V: Milesnick Ranch, Belgrade, Montana

- Region VI: Dave Wood Ranches, Coalinga, California

- Region VII, Nagel Cattle Company, Avon, South Dakota

Sponsored annually by Dow AgroSciences, the Environmental Stewardship Award Program recognizes cattle producers whose environmental stewardship practices are in- ventive, cost-effective, and contribute to environmental conservation.

Recipients of this top U.S. beef industry environmental award are selected by a committee of representatives from various university faculty, federal and state governments, and conservation and other environmental organizations. The national winner will be selected at the NCBA Annual Convention in February 2002 in Denver.

\section{NRCS Moves Toward Ecological Site Descriptions}

With increased demands on grazing and rangeland that include clean water, wildlife, open spaces and recreation, the management of these lands has become more complex.

The Natural Resources Conservation Service (NRCS) aims to improve its tools for managing rangelands by developing a process that addresses land use demands and helps make better decisions, according to NRCS rangeland management specialist Chuck Ring of Cheyenne, WY.

The result is the development of Ecological Site Descriptions which will replace the formerly used Range Site Descriptions. Ring coordinates the ecological site description effort across the Northern Plains.

Ring says this new approach estimates the land's existing abilities and at what point the land approaches a risk factor, rather than measuring the land only for its potential to sustain livestock or wildlife.

The process includes diagramming and describing all of the plant communities that occur on a site, along with a combination of natural events and management strategies that will cause one plant community to change to a different plant community.

"With this type of data, landowners and conservation planners are able to develop successful grazing strategies to meet broader land uses while mitigating environmental concerns," Ring says.

\section{Gary Frasier Retires From Agricultural Research Services}

After over 42 years in research, Gary Frasier retired from his research duties with USDA Agricultural Research Service on Aug. 31.

Thankfully, Frasier will still continue to serve as a dedicated Technical Editor for Rangelands and the Journal of Range Management.

Frasier started his research career in 1957 as an ARS Student Trainee in Colorado. In 1959, he began full time at the U.S. Water Conservation Lab in Phoenix, Arizona conducting research in the field of water conservation. Since 1990, Frasier has been with the Rangeland Resources Research Unit, Fort Collins, Colorado where he has been conducting hydrologic investigations of the shortgrass prairie and montane riparian regions.

Gary and his wife Jo have three adult children, Donna, Wendy and Clay.

"Resource Roundup" is compiled by Kindra Gordon. Contributions wel come at kindrag@tsln.com or 877347-9123. 


\section{Letter to Editor}

Dear Editor:

I wish to comment about part of an article by James L. Maynard page 21 of the August issue of Rangelands.

My comment is on the last part, Utilize FSA's Structure. To hear Mr. Maynard talk FSA is the only USDA agency that works with conservation programs. He speaks of FSA administering all of these programs when in fact if it deals with conservation all they do is issue cost share payments. The NRCS is the agency that administers cost share programs and sees that they are carried out in accordance with the contracts the NRCS writes.

I have worked for the NRCS for nearly 30 years and some what resent FSA receiving all of the credit for all of the conservation work that has gone on in this great country. I would suggest that Mr. Maynard get all facts in place before he writes such articles as this.

\section{James Luton}

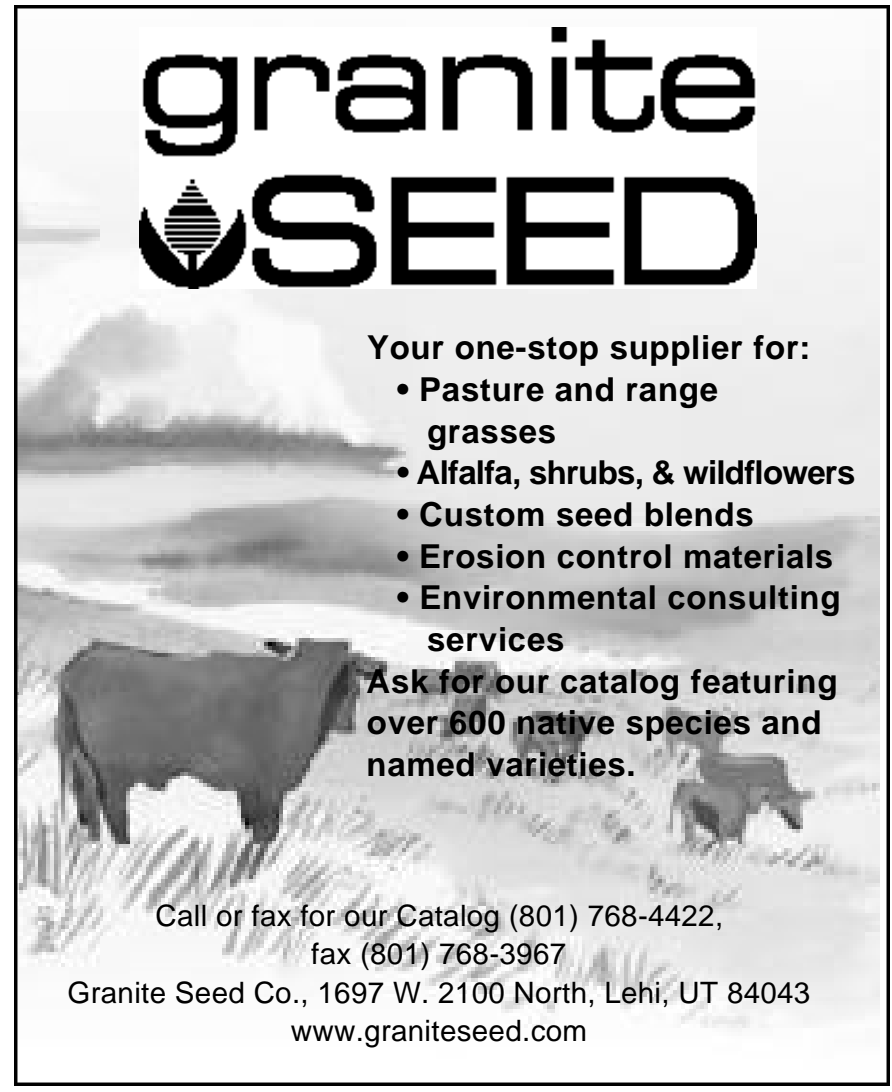

\section{Requiescat in Pace}

\section{Leo Brown}

H. Leo Brown, 92, of Eureka died on Saturday, May 26, 2001, at the Kansas Veterans Home in Winfield, Kansas.

He was united in marriage on June 12, 1943 to Florence.

He received his Masters degree at Fort Hayes State University and was the first State Biologist for the Kansas Fish and Game commission. He then spent 36 years as a Soil Conservationist with the United States Department of Agriculture retiring in 1978.

He spent his life working with people and the land. He was knowledgeable in his field and acted as a guest lecturer at univer-sities and wrote articles for various publications. He was a charter member of the Society For Range Management. During his career he discovered a new species of grass and helped name it.

Leo was a veteran of World War II, a member of the American Legion and a 40-year member of the VFW.

$\mathrm{He}$ is survived by his wife Florence; two sons Brent and Craig; one sister Doris Dieter and a grandson David.

In lieu of flowers the family suggests contributions be made in his name to the Greenwood County Hospital, 100 West 16th Street, Eureka, KS 67045 to the attention of Rhonda Eden or the Wichita VA Hospital, 5500 East Kellogg, Wichita, KS 67218 to the attention of the Voluntary Service Department or the Christian Congregational Church.

\section{Deadline Dates For Future Issues!!!}

The new deadline date for the Trail Boss News is the $15^{\text {th }}$ of the month prior to publication. For example, the December issue of The Trail Boss News needs to be to the publication office by the 15 th of November.

The deadline dates for ads, announcements, columns, etc. for Rangelands magazine are the 1st of the month prior to publication. For example, the December issue infromation needs to be to the production department by November 1 st.

\section{Email address: prich@starband.net}




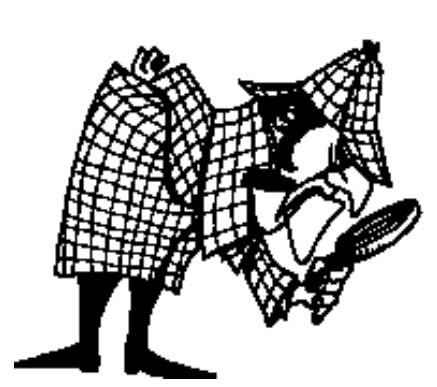

Sneak A Peek at the upcoming issue of Journal of Range Management

Adoption Of Brush Busters: Results Of Texas County

Extension SurveyPrinciples And Practices For Managing Rangeland Invasive Plants

Urs P. Kreuter, Heidi E. Amestoy, Darrell N. Ueckert, And W. Allan McGinty

Landowners have often been slow to adopt novel rangeland management practices. We conducted a mail survey of Texas County Extension Agents-Agriculture to determine their perceptions about Brush Busters, which has been widely adopted by Texas landowners. The Extension Agents indicated that Brush Busters has become popular because it is an inexpensive, convenient, safe, effective and predictable method for controlling brush, and because user-friendly information is widely available. Our findings suggest that greater effort must be placed on providing user-friendly messages to rangeland managers and Extension Agents, and the short-term efficacy of new technologies should be emphasized.

\section{Climatic Influences On Recruitment Of 3 Subspecies Of Artemisia Tridentata}

Aaron Maier, Barry Perryman, Richard Olson, And Ann Hild

Previous research suggested that big sagebrush (Artemsia triden tata Nutt.) recruitment occurs in pulses consistent with favorable climatic conditions. In 1997, 75 stem sections were collected from 9 stands of each of the 3 subspecies of big sagebrush in Wyoming. Annual growth rings were used to identify the year plants were established. Mean monthly precipitation and temperature records were compared to.years with high and low recruitment using logistic regression models at 3 geographic scales (single-stand, regional, statewide). Precipitation patterns appear to contribute significantly to recruitment of big sagebrush, however, responses among the 3. major subpecies were quite variable.

\section{Western Juniper Encroachment Into Aspen Communities In The Northwest Great Basin}

Travis G. Wall, Richard F. Miller, And Tony J. Svejcar

Western juniper is rapidly invading aspen stands in the northwest Great Basin. We determined the timing, extent, and some of the effects of this expansion. We found juniper invasion began in the 1890s, peaked between 1900 and 1939, replaced or dominated $35 \%$ and common in $60 \%$ of the aspen communities measured, and significantly influenced soil nutrient composition. Without active management, aspen will continue to decline in this region and may be permanently lost.

\section{Suppression of Annual Bromes Impacts Rangeland: Vegetation Responses}

Marshall R. Haferkamp, R.K. Heitschmidt, Elaine E. Grings, Michael D. MacNeil And Michael G. Karl

Japanese and downy brome have invaded many acres of the Northern Great Plains at the expense of the more desirable native grasses. We evaluated the impact of brome suppression on perennial grass production and inter-seasonal forage quality dynamics. The forage quantity varied by date and year but brome suppression increased crude protein concentration in the western wheatgrass. Annual bromes are influenced by growing conditions but there is an improvement in native species forage nutritional quality with suppression of the bromes.

\section{Long-Term Plant Community Development As Influenced By Revegetation Techniques}

Gregory J. Newman And Edward F. Redente

Most reclamation studies are short-term in nature and provide little insight into the long-term effects of initial revegetation practices such as seeding method, irrigation, and fertilization. Longterm plant community development was assessed after 20 years from the time that a disturbed site was seeded. Broadcast seeding of a native mixture that was irrigated for two years appeared to be the most effective long-term combination of cultural practices. The results from this study provide important information for making better predictions as to the importance and long-term effect of revegetation practices in arid and semiarid regions.

\section{Suppression Of Annual Bromes Impacts Rangeland: Animal Responses}

Marshall R. Haferkamp, Elaine E. Grings, RK. Heitschmidt, Michael D. MacNeil And Michael G. Karl

Annual bromes can alter the seasonal patterns of forage production and quality which may require changes in management for efficient use of the infested rangelands. We evaluated the impact of brome suppression on livestock performance. With brome suppression, native perennial grasses and forbs were increased in the animal diets which increased the daily steer gains. Suppression of annual bromes will improve livestock performance on semiarid rangelands. 
Adaptation Of Perennial Triticeae To The Eastern Central Great Plains

Kenneth P. Vogel And Kevin L. Jensen

The tribe Triticeae contains over 250 perennial grass species many of which have not been evaluated previously in the Central Great Plains, USA. We evaluated a subset of perennial Triticeae which included over 100 accessions of 55 different species in eastern Nebraska during 1994-1996 to determine their survival and forage productivity. Triticeae that survived and had acceptable forage yields during the period of the trial were the Agropyron's, Psathyrostachys', Thinopyron's, some Elymus, several previously unevaluated Leymus species, and Pascopyrum. The study provides an example of how the rapidly emerging field of genomics can have practical applications to grasslands and rangelands.

\section{Influence Of Off-Stream Supplements On Streambanks Of Riparian Pastures}

\section{Michael L. Mclnnis And James B Mclver}

Preventing or reducing accelerated erosion of streambanks in grazed riparian pastures is a major concern in many areas. The practice of providing cattle offstream water and trace mineralized salt to lessen negative impacts of grazing on streambank stability and cover was evaluated in northeastern Oregon. Off-stream supplements attracted animals away from the riparian area and reduced the proportion of streambanks that were both unstable and uncovered, but did not reduce the potential of accelerated erosion compared to pastures not provided supplements.

\section{Tracked Vehicle Impacts To Vegetation Structure And Soil Erodibility}

William P. Grantham, Edward F. Redente, Calvin F. Bagley, And Mark W. Paschke

Large military equipment training results in excessive soil erosion and ecosystem degradation. The effect of simulated M1A2 Abrams battletank maneuvers on grassland plant canopy and soil erodibility was evaluated using a portable wind tunnel. Tank maneuvers resulted in a decrease of vertical vegetation structure with increased potential soil loss from wind. The results from this study will be important for establishing guidelines for military training activity and in understanding the relationship between vegetation structure and wind erodibility of soils.
Frequency Grid - A Simple Tool For Measuring Grassland Establishment

Kenneth P. Vogel And Robert A. Masters

Simple, reliable tools are needed by land managers to quantify establishment success when reseeding pastures or rangeland. A frequency grid metal frame was designed to measure seedling or plant establishment success for a single species, mixture of species, or a single species of a mixture. The frequency grid is inexpensive to make, requires minimal training, permits rapid measurements, and provides a meaningful estimate of plant density. The frequency grid has been used to document herbicide efficacy and seeding rates for grassland establishment in the central Great Plains and should be easily adaptable for use in other geographic regions.

\section{Mesquite And Grass Interference With Establishing} Redberry Juniper Seedlings

W.R. Teague, S.L. Dowhower, S.G. Whisenant And E. FloresAncira

Excessive cover of juniper reduces forage production, interferes with livestock management, and diminishes the watershed and wildlife habitat of rangelands. We evaluated if juniper seedlings were differentially suppressed in the presence of different grass species and to what extent mesquite trees affect juniper seedlings. Juniper seedlings were suppressed by all of the grasses and the presence of mesquite trees benefited juniper seedlings by increasing nutrient availability beneath canopies, reducing summer temperatures and providing no measurable above- or below-ground competition. Managing for vigorous grass with low mesquite cover is the best way to limit the juniper invasion rate.

Chemical Composition And Livestock Ingestion Of Carob (Ceratonia siliqua L.)

Carob pods of the evergreen sclerophyllous tree grow in great abundance in Jordanian forests and rangelands but their use as a feed source for sheep is unknown. Pods and seeds were analyzed for their chemical composition and the effects of ingestion by sheep and goats on germination were investigated. Pods and seeds contain enough crude protein and energy to meet the maintenance and lactation requirements of ewes, but $\mathrm{Ca}$ and $\mathrm{P}$ contents were not adequate. Sheep and goat are very important dispersal agents for carob seeds and thus, instrumental in maintaining and spreading carob tree populations. 


\section{Nutritional Dynamics Of 7 Northern Great Basin Grasses}

Dave Ganskopp And Dave Bohnert

The seasonal nutritional dynamics of northern Great Basin grasses have not been described under one cover. We analyzed forage quality attributes of 7 different grasses for 8 month periods in 1992, a drier than average, and 1993, a wetter than average year. Grasses were of higher quality and responded to mid-growing season rains when moisture was limiting, and advanced quickly to maturity with rapid declines in forage quality and no response to growing season precipitation when with more favorable growing conditions. These findings will help forage, livestock, and wildlife managers access and respond to the nutritional needs of their stock.
Effects Of Prescribed Fire On Sand Shinnery Oak Communities

Wade C. Harrell, Samuel D. Fuhlendorf, And Terrence G. Bidwell

It has been suggested that reduction in fire has allowed shrubs to gain dominance in sand shinnery oak communities. We determined the influence of fire on shrub composition and structure of sand shinnery oak communities by estimating plant canopy cover, shrub composition, and vegetation structure. Fire temporarily (K 3 years) altered vegetation structure of sand shinnery oak communities; however, rapid recovery following fire did not indicate any long-term changes in structure and composition. Restoration of herbaceous dominance in these shrublands through the use of prescribed fire would be difficult due to rapid recovery of shrubs and slow fine fuel accumulation.

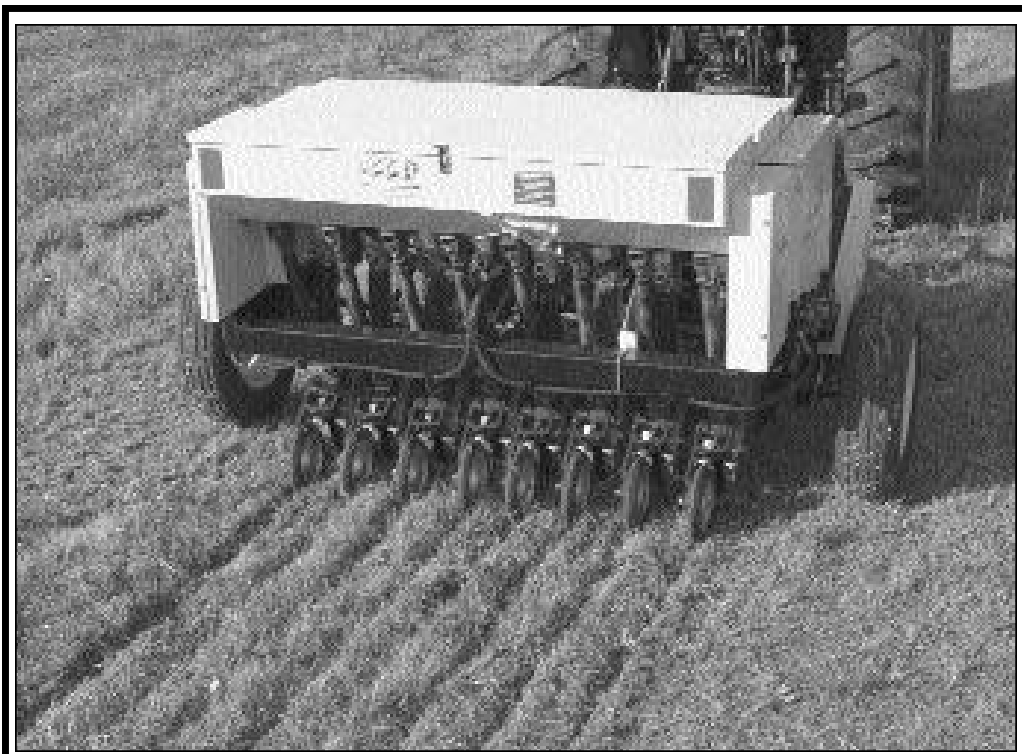

\section{PERFORMANCE.}

Superior design, top-quality materials, and meticulous hand-built construction are what set truax seeding equipment apart from the competition. You'll find these in every truax seeder from the small, hand-cranked, Seed Slinger that lets you broadcast fluffy seeds and grasses together by hand, to the famous Flex II seed drill pictured at left, which interseeds native grasses, turf grasses, fluffy seeds, small grains, wildflowers, even legumes.

The result is outstanding seeding performances even in the most challenging environments! and durability that will last for decades. If you want dependable seeding performance, you want a

The "Trillion" - shown at right, is the ideal broadcast seeder for wildflowers, turf grasses, and fluffy/chaffy prairie seeds. Unit has three types of seed boxes and combines the truax seed delivery system with two Brillion ${ }^{\circledR}$ cultipack rollers.

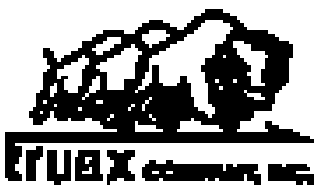

\section{For more information call} (763) 537-6639 or visit www.truaxcomp.com

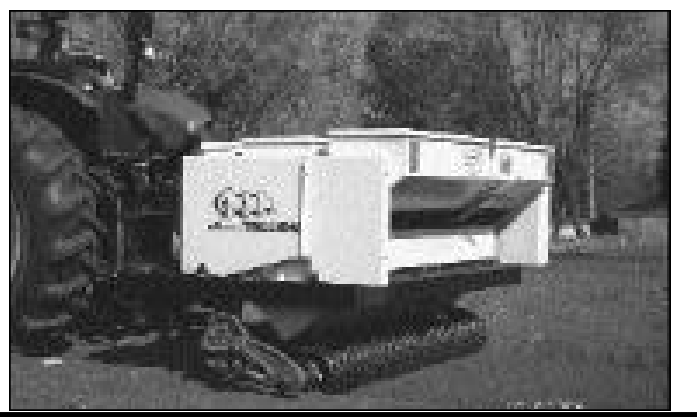




\title{
Browsing The Literature
}

\author{
Jeff Mosley
}

This section reviews new publications available about the art and science of rangeland management. Personal copies of these publications can be obtained by contacting the respective publisher or senior author (addresses shown in parentheses). Suggestions are welcomed and encouraged for items to include in the future issues of Rangelands.

\section{Animal Ecology}

A landscape analysis of cougar distribution and abundance in Montana, USA. S.J. Riley and R.A. Malecki. 2001. Environmental Management 28:317-323. (Dept. of Natural Resources, Cornell Univ., Ithaca, NY 14853). Attributed recent increases in the distribution and population of mountain lions to increased numbers of deer and elk.

Factors limiting a bighorn sheep population in Montana following a dieoff. T.A. Enk, H.D. Picton, and J.S. Williams. 2001. Northwest Science 75:280-291. (22 Herrada Rd., Sante Fe, NM 87505). Drought effects on the nutritive quality of summer forage compromised the immune systems of bighorns.

Influence of predation by mountain lions on numbers and survivorship of a feral horse population. J.W. Turner and M.L. Morrison. 2001. Southwestern Naturalist 46:183-190. (Dept. of Physiology \& Molecular Medicine, Medical College of Ohio, Toledo, OH 43699). Predation of foals by mountain lions is significantly limiting a feral horse herd along the California-Nevada border.

Preference for polyethylene glycol by sheep fed a quebracho tannin diet. J.J. Villalba and F.D. Provenza. 2001. Journal of Animal Science 79:2066-2074. (Dept. of Rangeland Resources, Utah State Univ., Logan, UT 84322). Results indicate that it may be possible to formulate self-regulated supplements that help livestock detoxify tannins in their forage.

Relationship between terrain use and performance of beef cows grazing foothill rangeland. D.W. Bailey, D.D. Kress, D.C. Anderson, D.L. Boss, and E.T. Miller. 2001. Journal of Animal Science 79:1883-1891. (Northern Agr. Research Center, Montana State Univ., Star Route 36 Box 43, Havre, MT 59501). "Performance of cows that used more rugged topography was similar to cows using gentler terrain."

Small mammals in successional prairie woodlands of the northern Great Plains. M.A. Rumble and J.E. Gobeille. 2001. USDA Forest Service Rocky Mountain Research Station RP-28. (Publications, Rocky Mountain Research Station, $32425^{\text {th }}$ St., Ogden, UT 84401). Diversity and abundance of small mammals will be maximized by retention of all seral stages in prairie woodlands.

\section{Grazing Management}

A comparison of native tallgrass prairie and plains bluestem forage systems for cow-calf production in the southern Great Plains. S.W. Coleman, W.A. Phillips, J.D. Volesky, and D. Buchanan. 2001. Journal of Animal Science 79:1697-1705. (USDA-ARS, 22271 Chinsegut Hill Rd., Brooksville, FL 34601). Cow-calf production was most profitable from a tallgrass prairie forage system, but a forage system of plains bluestem and wheat pastures was more profitable if excess hay from this system was sold as a cash crop.

Manipulating cattle distribution with salt and water in large arid-land pastures: A GPS/GIS assessment. D. Ganskopp. 2001. Applied Animal Behaviour Science 73:251262. (USDA-ARS, Eastern Oregon Agr. Research Center, HC 71 4-51 Hwy. 205, Burns, OR 97720). Movement of drinking water to distant points in pastures effectively altered cattle distribution, but relocating salt did not.

\section{Improvements}

Forage production after thinning a natural loblolly pinehardwood stand to different basal areas. D.G. Peitz, M.G. Shelton, and P.A. Tappe. 2001. Wildlife Society Bulletin 29:697-705. (National Park Service, 6424 W. Farm Rd. 182, Republic, MO 65738). "Results of our study indicate that managers can manipulate forage production by thinning stands to prescribed basal areas..."

Multi-species grazing and leafy spurge. S. Merrit, C. Prosser, K. Sedivec, and D. Bangsund. 2001. (TEAM Leafy Spurge, USDA-ARS, 1501 N. Central, Sidney, MT 59270). This 27-page color brochure explains how to use multispecies grazing as an effective leafy spurge management tool.

Response of breeding Florida grasshopper and Bachman's sparrows to winter prescribed burning. W.G. Shriver and P.D. Vickery. 2001. Journal of Wildlife Management 65:470475. (College of Environmental Sci. \& Forestry, SUNY, 1 Forestry Dr., Syracuse, NY 13210). The fire-free interval needs to be 3 years or less to help sustain two species of sparrows that are declining in central Florida.

\section{Measurements/Sampling}

Adaptive management on public lands in the United States: Commitment or rhetoric? W.H. Moir and W.M. Block. 2001. Environmental Management 28:141-148. (USDA Forest Service, 2500 Pine Knoll Dr., Flagstaff, AZ $86001)$. Suggests that public land management agencies presently are incapable of performing the on-the-ground monitoring needed to implement adaptive management strategies. 
Riparian health assessment for streams and small rivers: Field workbook. L. Fitch, B.W. Adams, and G. Hale, eds. 2001. Cows and Fish Program, Lethbridge, AB, Canada. (website: www.cowsandfish.org and follow the links to Community Tools for an online ordering form). Presents a qualitative checklist for characterizing the condition of riparian ecosystems.

\section{Plant/Animal Interactions}

Effects of grazing on the demography and growth of the Texas tortoise. R.T. Kazmaier, E.C. Hellgren, D.C. Ruthven, and D.R. Synatzske. 2001. Conservation Biology 15:10911101. (Dept. of Zoology, Oklahoma State Univ., Stillwater, OK 74078). Texas tortoises are tolerant of moderate cattle grazing.

Managing exotic grasses and conserving declining species. D.J. Germano, G.B. Rathbun, and L.R. Saslaw. 2001. Wildlife Society Bulletin 29:551-559. (Dept. of Biology, California State Univ., Bakersfield, CA 93311). Concluded that moderate to heavy livestock grazing is the best way to decrease dense herbaceous cover and improve the habitat of several threatened or endangered ground-dwelling vertebrates.

Vegetation change following removal of keystone herbivores from desert grasslands in New Mexico. D.E. Ryerson and R.R. Parmenter. 2001. Journal of Vegetation Science 12:167-180. (R. Parmenter, Dept. of Biology, Univ. of New Mexico, Albuquerque, NM 87131). Twenty years of exclusion from livestock and prairie dogs had very little effect on desert grasslands in central New Mexico.

\section{Plant Ecology}

Conifer density increases in semi-desert habitats of British Columbia in the absence of fire. J.S. Turner and P.G. Krannitz. 2001. Northwest Science 75:176-182. (P. Krannitz, Pacific Wildlife Research Center, 5421 Robertson Rd, RR 1, Delta, BC V4K 3N2, Canada). Ponderosa pine and Douglasfir trees significantly invaded grasslands of southern British Columbia from 1938 to 1985 and from 1985 to 1996.

Effects of fire, grazing, and the presence of shrubs on Chihuahuan desert grasslands. P.B. Drewa and K.M. Havstad. 2001. Journal of Arid Environments 48:429-443. (USDA-ARS, Jornada Experimental Range, Box 30003, MSC 3JER, Las Cruces, NM 88003). Precipitation immediately following early summer fires may be critical for recovery of desert grasslands dominated by black grama.

Mesquite establishment in arid grasslands: An experimental investigation of the role of kangaroo rats. T.J. Valone and D. Thornhill. 2001. Journal of Arid Environments 48:281288. (Dept. of Biology, St. Louis Univ., St. Louis, MO 63103). Herbivory by kangaroo rats or rabbits may hinder mesquite seedling establishment more so than seed-caching by kangaroo rats.
Montana's noxious weeds. M. Pokorny and R. Sheley. 2001. Montana State Univ. Extension Bulletin 159. (\$2; Extension Publications, Culbertson Hall, Montana State Univ., Bozeman, MT 59717). This pocket-sized brochure contains descriptions and color pictures of the 23 plants on Montana's statewide noxious weed list.

\section{Socioeconomics}

Purchase of development rights: Conserving lands, preserving western livelihoods. Western Governor's Association, Trust for Public Land, and National Cattlemen's Beef Association. 2001. (Western Governor's Association, 1515 Cleveland Place, Suite 200, Denver, CO 80202-5114). This 24-page bulletin is a primer for state policymakers and landowners interested in establishing programs to preserve open space and agricultural lands.

Ranch conversations: A blueprint for conserving species and rural lifestyles. Western Governor's Association, High Plains Partnership for Species at Risk, and Lesser Prairie Chicken Interstate Working Group. 2001. (Western Governor's Association, 1515 Cleveland Place, Suite 200, Denver, CO 80202-5114). This 16-page brochure describes the efforts of 5 states-Colorado, Kansas, New Mexico, Oklahoma and Texas-to directly involve landowners in conservation planning for the lesser prairie chicken.

Author is professor of range science and Extension range management specialist, Dept. of Animal and Range Sciences, Montana State Univ., Bozeman, Mont. 59717. 


\section{Book Review}

Country Properties. By John K. Hoff and Jennifer L. Hoff. 1999. The Seville Group, 17 S. Briar Hollow, Suite 205, Houston, TX 77027, USA. 192 +-xiv p. US\$21.95 paper. ISBN 0-96664193-0-8.

The $20^{\text {th }}$ Century began with the United States having primarily a rural population with much of the land still remote and undeveloped. The move from rural to urban began during the drought and depression of the 1930's. World War II accelerated the move and it continues to the present time with a continual decrease in the number of farmers and ranchers. However, a new trend began near the end of the $20^{\text {th }}$ Century: a move from urban to rural. In contrast to the mostly poor settlers who moved west 100 years ago looking for opportunities to own land and make a living for their families, this new migration consist of successful, established individuals. They are purchasing farms and ranches, not to make a living for their families, but to add a rural experience to their lifestyles, and to diversify their investment portfolios. Country Properties is a well-written book that provides guidance to the prospective new landowner. In the preface, the authors state that "While most potential buyers were sophisticated in the business world, they were almost completely ignorant about how to become a successful rancher. The most astounding thing about this mentality was their overconfidence in thinking that they knew what they were doing despite their lack of relevant knowledge."

The book is presented not as a technical how-to handbook, but as a guide to alert the new owners of practical management and economic matters that they need to consider. Rather than try to provide detailed technical information, the authors take the approach of introducing the topic and telling the reader where to look for more detailed specific information. They begin with a brief, interesting history of the development of the ranching industry and name a few of the prominent historical ranches and some of the high profile "new" ranchers.

Chapter 1, Ranch Acquisition, discusses what a prospective buyer should consider when shopping for a ranch. They state that traditionally the three most important factors are "location, location, location" but go on to discuss the importance of considering soils, topography, water, and improvements. The authors have a strong bias for high potential sites with either high rainfall or irrigation. In addition to these factors they consider taxes and land use controls, mineral and water rights, existing mortgages, legal title, and financing for the ranch, livestock and new improvements.

Chapter 2, Type of Cattle Operation and Breed of Beef Cattle, begins with a brief description of commercial cow/calf and stocker operations and then moves on to registered cattle operations. The registered operation is obviously the first love of the authors, reflecting the family heritage of Professor John I. Miller (Animal Science, Cornell University). There is a listing and brief description of the history and principal traits of all breeds registered in the U.S., with addresses and telephone numbers of all the breed associations listed in an appendix.

Part 2, Operating the Ranch, consists of 5 chapters. Chapter 3, Trying to Make a Go of It, discusses the difficulties of making a positive return on the operation of the ranch. They exclude any consideration of return to investment in real estate, preferring to keep that as a separate enterprise. They do advise the owner to consider appreciation of real estate as a return on their investment, however, they are careful not to present ranching as a "get rich quick" investment. Their concern is that the prospective buyers have a realistic understanding of the economic dangers of investing in a ranching enterprise. An economic case scenario for a ranch illustrating negative net income per cow and eight strategies for improving the net income are presented and discussed. Chapter 4 is a short chapter that presents several important considerations related to eye appeal and investments. Chapter 5, Managing Pastures and Hay Crops, is, in my opinion, the weakest link in the book. The concept of rangelands as a basis for ranching is totally absent. While the book purports to cover all regions of the U.S., it only considers the principal agronomic forages and focuses on intensive production using irrigation and fertilizer. With this focus, it is not surprising that the economic example presented had a negative net income per cow. A chapter giving consideration to rangelands and ecological management of forages would greatly enhance the value of this book for most prospective buyers.

Chapter 6, Some Thoughts on Fencing and Improvements, provides some good advice on where to get information on construction of facilities, but their fence design is more appropriate for regions with deep soil and high rainfall than for shallow, arid, rangeland soils. Chapter 7, Managing the Beef Cattle Herd, is the longest and most specific chapter related to ranching. It provides sound information, but is oriented almost exclusively to registered cow/calf operations. Chapter 8 has a concise presentation of several different marketing strategies.

Part 3-Exotic Diversions - contains one chapter on pecans. This is the most complete chapter in the book and reflects a strong personal interest and involvement of the authors in commercial pecan production. It contains an excellent detailed discussion of pecan production and provides references for additional information and support. This part of the book could be expanded to include at least a chapter on wildlife and outdoor recreation. The absence of any information on the potential role of wildlife on the ownership and management of the ranch is an obvious omission.

Part 4-Winding Down - has one brief chapter - The Transfer of the Ranch. They suggest that the prospective buyers should consider when and how they would transfer ownership of the ranch, either by sale, gift, or estate. The authors' extensive experience in real estate shows in the detailed checklist they present for sellers to use in preparing to market their property.

The book is written with a very non-technical vocabulary and also contains a glossary of terms that may be confusing to persons with no agricultural or real estate experience. It is very readable and will provide a valuable guide for the prospective new rancher. It addresses a variety of topics that prospective buyers should consider. While it is primarily oriented to high rainfall or irrigated lands, it would provide a good complement to The New Ranch Handbook: A Guide to Restoring Western Rangelands for persons considering buying rangeland.-Mort Kothmann, Texas A\&M University, College Station, Texas. 


\section{Society for Range Management}

FOUNDING MEMBERS(1948-1952)*

Harlan G. Arnold

John L. Artz

William M. Beaty

Robert E. Bement

Lester J. Berry

John W. Bohning

Vernon C. Brink

Robert R. Brown

John E. Butcher

James J. Butler

Ross L. Campbell

Eleanor M. Cross

Richard S. Driscoll

Calvin M. Emerson

Lester Fluckiger

F. Robert Gartner

Max C. Green

Donald W. Hedrick

O. N. Hicks

Lynn F. James

Peter N. Jensen

Thomas N. Johnsen, Jr.

Dale A. Jones

Wayne Kessler

James O. Klemmedson

James W. Lancaster

William A. Laycock

Kenneth B. Leiting

Robert J. Leonard

I. D. Maldonado

James I. Mallory

William L. Mathews

V. P. McConnell

Lester A. McKenzie

Mrs. Eleanor McLaughlin

John Merrill

Robert W. Metlen

Wayne H. Miles

R. Keith Miller

Allen D. Morton

Thomas E. Mullings

Robert B. Murray, I

Joseph F. O'Rourke

Karl G. Parker

W. C. Pendray

Ivan R. Porter

Bob J. Ragsdale

Frank Rauzi

C. Hardy Redd

Walter M. Risse

Robert L. Ross

Sid E. Salzman

Charles N. Saulisberry

Sylvester Smoliak

E. Malcolm Strom

Clair E. Terrill

Rose E. Thompson

John F. Vallentine

William J. Waldrip

Clair M. Whitlock

Richard P. Williams

Robert E. Williams

Lewis L. Yarlett

Rex S. Zobell

\section{CHARTER MEMBERS(1947-1948)}

E. William Anderson

Walter D. Armer

Alan A. Beetle

George E. Bradley

Dwight R. Cable

C. Wayne Cook

Sterle E. Dale

Robert A. Darrow

Everett R. Doman

Marion E. Everhart

John M. Fenley

John S. Forsman

John D. Freeman

Paul F. Gilbert

Charles A. Graham

Lowell K. Halls

Robert W. Harris

Grant A. Harris

Harold F. Heady

Elver M. Hodges

Clark E. Holscher

Robert R. Humphrey

Richard M. Hurd

William D. Hurst

Donald N. Hyder

George W. Kansky

Paul A. Krause

S. Clark Martin

E. H. McIlvain

Glenn H. Mueller

Gene F. Payne

Joseph F. Pechanec

Rudy J. Pederson

Roald A. Peterson

Charles E. Poulton

J. Boyd Price

Laurence E. Riordan

Max E. Robinson

Robert S. Rummell

Charles M. Schumacher

Weldon O. Shepherd

Harry W. Springfield

Gerald W. Thomas

George T. Turner

A. H. Walker

Wayne W. West

*Founding members are members who joined in the first 5 years. 


\section{Holiday Memories}

Do you have a special holiday item you would like to share with our Rangelands readers? In some of our past December Rangelands issues the editors have invited memories, photos, favorite holiday recipes, etc. If you have something you would like to share please send it by November 1, 2001 to prich@starband.net 


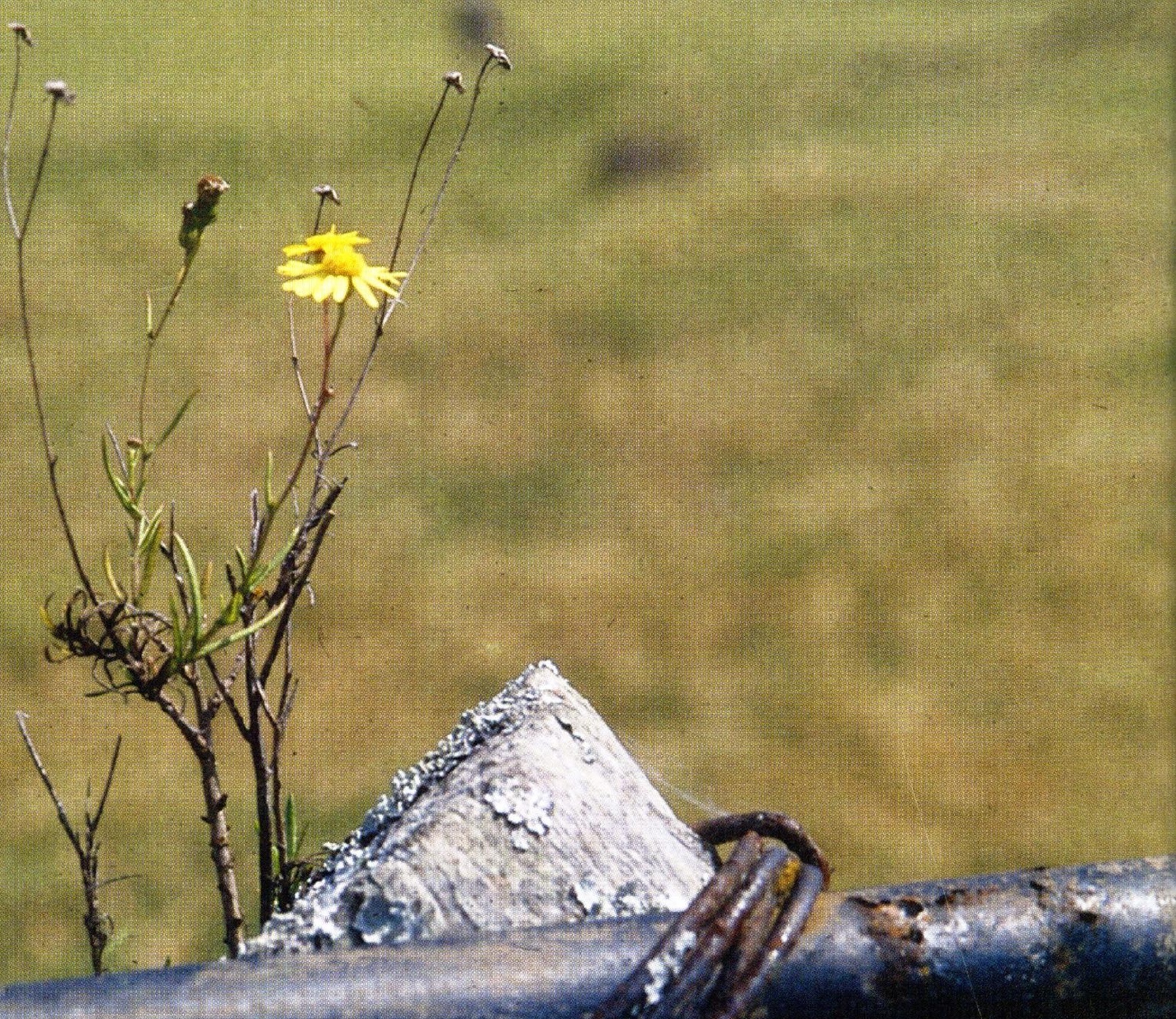

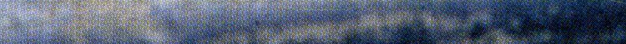
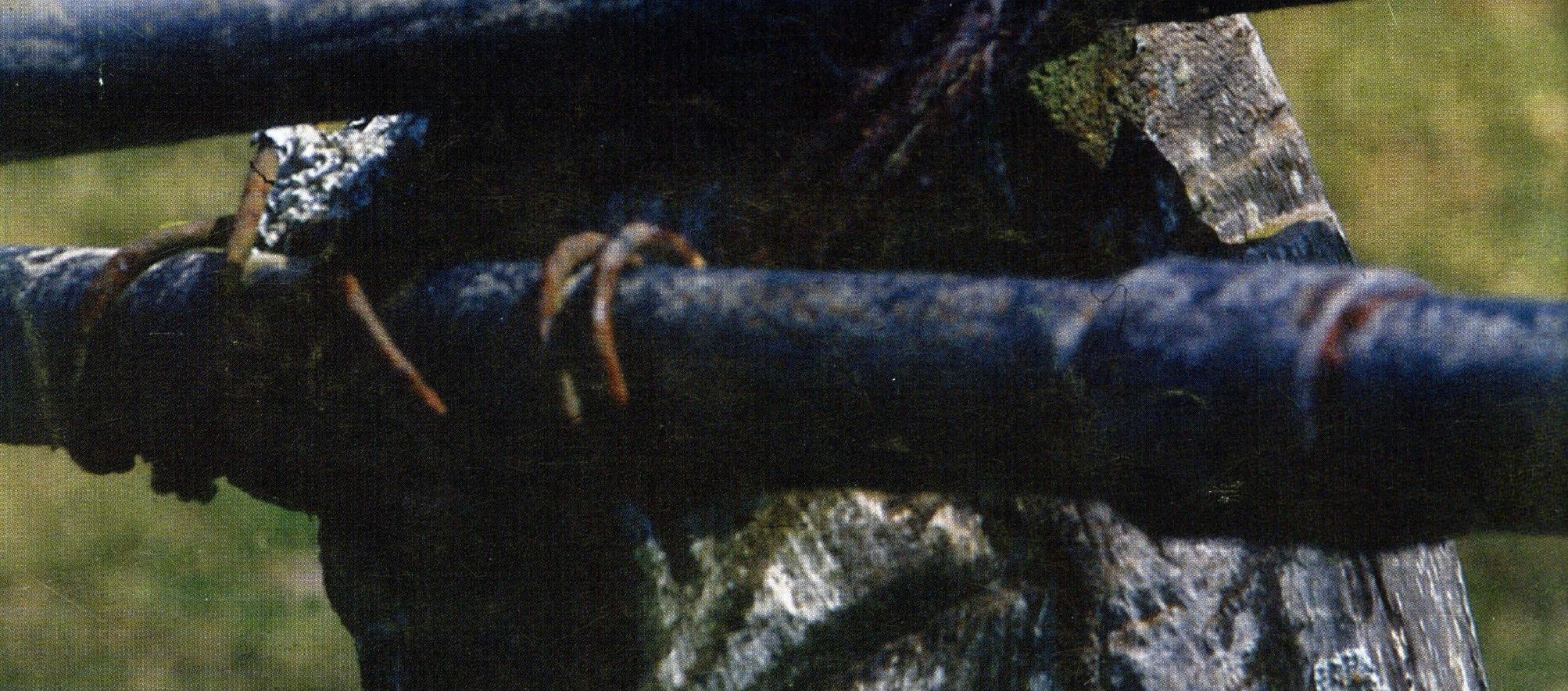